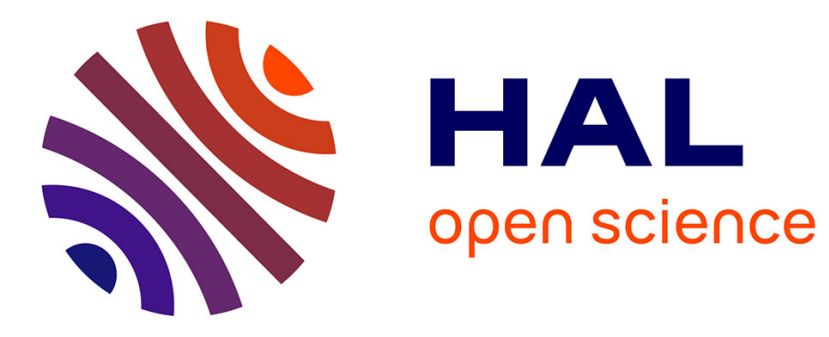

\title{
A new early Late Oligocene (MP 26) continental vertebrate fauna from Saint-Privat-des-Vieux (Alès Basin, Gard, Southern France)
}

Monique Vianey-Liaud, Bernard Comte, Bernard Marandat, Stéphane Peigne, Jean-Claude Rage, Jean Sudre

\section{To cite this version:}

Monique Vianey-Liaud, Bernard Comte, Bernard Marandat, Stéphane Peigne, Jean-Claude Rage, et al.. A new early Late Oligocene (MP 26) continental vertebrate fauna from Saint-Privat-des-Vieux (Alès Basin, Gard, Southern France). Geodiversitas, 2014, 36 (4), pp.565-622. 10.5252/g2014n4a4 . hal-01324886

\section{HAL Id: hal-01324886 \\ https://hal.sorbonne-universite.fr/hal-01324886}

Submitted on 1 Jun 2016

HAL is a multi-disciplinary open access archive for the deposit and dissemination of scientific research documents, whether they are published or not. The documents may come from teaching and research institutions in France or abroad, or from public or private research centers.
L'archive ouverte pluridisciplinaire HAL, est destinée au dépôt et à la diffusion de documents scientifiques de niveau recherche, publiés ou non, émanant des établissements d'enseignement et de recherche français ou étrangers, des laboratoires publics ou privés. 


\title{
A new early Late Oligocene (MP 26) continental vertebrate fauna from Saint-Privat-des-Vieux (Alès Basin, Gard, Southern France)
}

\author{
Monique VIANEY-LIAUD \\ Institut des Sciences de l'Évolution, \\ Université Montpellier 2, CNRS, IRD \\ case courrier 64, place Eugène Bataillon \\ F-34095 Montpellier cedex 5 (France) \\ monique.vianey-liaud@univ-montp2.fr
}

Bernard COMTE†

Institut des Sciences de l'Évolution,

Université Montpellier 2, CNRS, IRD case courrier 64, place Eugène Bataillon

F-34095 Montpellier cedex 5 (France)

Bernard MARANDAT

Institut des Sciences de l'Évolution,

Université Montpellier 2, CNRS, IRD case courrier 64, place Eugène Bataillon

F-34095 Montpellier cedex 5 (France)

\section{Stéphane PEIGNÉ}

CR2P - MNHN, CNRS, UPMC-Paris 6,

Muséum national d'Histoire naturelle,

57 rue Cuvier, case postale 38, F-75231 Paris cedex 5 (France)

Jean-Claude RAGE

CR2P - MNHN, CNRS, UPMC-Paris 6,

Muséum national d'Histoire naturelle,

57 rue Cuvier, case postale 38, F-75231 Paris cedex 5 (France)

Jean SUDRE

Institut des Sciences de l'Évolution,

Université Montpellier 2, CNRS, IRD

case courrier 64, place Eugène Bataillon

F-34095 Montpellier cedex 5 (France) 
KEY WORDS

mammals,

"reptiles", amphibians, evolution,

diversity, biochronology, Upper Oligocene, Southern France, new genus, new species.

\section{MOTS CLÉS}

mammifères, " reptiles ", amphibiens,

évolution,

diversité

biochronologie,

Oligocène supérieur,

France du Sud,

genre nouveau, espèces nouvelles.

\section{ABSTRACT}

This fauna results from the short-time excavation of a restricted fossiliferous level, following the opening of a trench for the installation of a gas conduit. Even if the amount of sediment is limited, the diversity of the fauna approaches that of other contemporaneous localities. Among the 40 vertebrate species, a few are amphibious, and most terrestrial. Among them, biochronological markers like Issiodoromys pauffiensis Vianey-Liaud, 1987 (Rodentia, Theridomyidae) are better defined. This species is compared with the type population of the MP 26 Mammalian Paleogene standardlevel (Mas-de-Pauffié, Lot; early Chattian). In addition, evolutionary grades hitherto unknown are described for several less well represented species: a sciurid rodent Comtia n. gen., a molossid bat (Cuvierimops sp.), a probable talpid, and the hyaenodontid Thereutherium thylacodes Filhol, 1876. The familial assignment of the snake Platyspondylia Rage, 1974 is discussed. The locality yielded the possible earliest shinisaurian lizard. The diversity of this new vertebrate fauna is compared to that of several localities from the same biochronological level (mainly Mas-de-Pauffié, Saint-Menoux, SaintHenri/Saint-André, Mümliswil-Hardberg and Oensingen 11). The choice of Mas-de-pauffié as the reference-locality for MP 26 is therefore supported.

\section{RÉSUMÉ}

Une nouvelle faune de vertébrés continentaux de l'Oligocène supérieur (MP26) à Saint-Privat-des-Vieux (Bassin d'Alès, Gard, Sud de France).

Cette faune résulte de la brêve exploitation d'un petit niveau fossilifere mis au jour lors de l'ouverture d'une tranchée pour l'installation d'une conduite de gaz. Même si la quantité de sédiment fossilifere accessible était limitée, la diversité de la faune récoltée est du même ordre que celle de localités contemporaines. Parmi les 40 espèces de vertébrés reconnues, quelques unes sont amphibies mais la plupart est terrestre. Parmi elles, des marqueurs biochronologiques tel Issiodoromys pauffiensis Vianey-Liaud, 1987 (Rodentia, Theridomyidae) sont mieux définis. Cette espèce est comparée à la population type du niveau repère mammalien du Paléogène MP 26 (Mas-de-Pauffié, Lot; Chattien inférieur). De plus, des stades évolutifs jusque là inconnus sont décrits pour quelques espèces moins abondantes : c'est le cas d'un rongeur Sciuridae Comtia n. gen., d'une chauve-souris Molossidae (Cuvierimops sp.), d'un probable Talpidae, et du Hyaenodontida Thereutherium thylacodes Filhol, 1876. L'attribution familiale du serpent Platyspondylia Rage, 1974 est discutée. L'un des lézards du gisement pourrait être le plus ancien Shinisauria. La diversité de cette nouvelle faune est comparée avec celle de plusieurs faunes contemporaines (principalement Mas-de-Pauffié, Saint-Menoux, SaintHenri/Saint-André Mümliswil-Hardberg et Oensingen 11). Le choix de Mas-de-Pauffié comme localité-type du niveau-repère MP 26 est conforté.

\section{INTRODUCTION}

The vertebrate faunas from the early Chattian (mammalian reference-level MP 26), have long remained incompletely documented or partially studied. There was only one monograph published on the SaintMenoux mammal fauna (Allier, France; Hugueney 1980, Hugueney \& Guérin 1981). The descriptions 
of a part of the mammalian taxa have been published separately from other contemporaneous localities (e.g., Vianey-Liaud et al. 1995, for Mas-de-Pauffié, Lot, France; Ménouret \& Guérin 2009, for SaintHenri/Saint-André, Bouches-du-Rhône, France; Freudenthal et al. 1994, for Mirambueno4C, province of Teruel, Spain). In some cases, preliminary faunal lists only have been provided without any description or illustration (e.g., Engesser \& Mödden 1997, for Oensingen 11, Switzerland). Among these localities, Mas-de-Pauffié was recognized with some reticenses as the reference - locality for MP 26 (Vianey-Liaud \& Schmidt-Kittler 1987), because it is a fissure-filling. It has been possibly considered as "scanty" (BiochroM 1997: 778), and the prevention of some paleontologists against fissure-fillings as reference-localities has been strongly expressed.

Since 1997, several faunas that are not fissurefillings were discovered, like Moissac III (Lihoreau et al. 2009) and Saint-Privat-des-Vieux, and some previously known localities have been enriched by new fossils (e.g., Mas-de-Pauffié, Lot; Oensingen11, Switzerland). The quality and diversity of the fossil vertebrates from Saint-Privat-des-Vieux (Gard, France) allowed us to make an extensive study not only of mammals but also of all vertebrate taxa. The fossiliferous assemblage includes 40 species; among them 19 are mammals, one is a freshwater fish, six are amphibians, at least one a turtle, two crocodiles and 11 squamates that allowed correlation of the Saint-Privat-des-Vieux fauna to the lower Chattian.

This fauna represents a new stratigraphic marker in the Oligocene Alès basin, on the basis of the faunal assemblage and the evolutionary stage of mammals, especially rodents (Bonnet et al. 2011: table 1). Indeed, the Oligocene Alès semi-graben (NE-SW; Gard, France) has yielded several fossiliferous localities with mammals. Their age ranges between the Late Eocene (Monac, MP 19; Vianey-Liaud \& Ringeade 1993) and the Late Oligocene (BoujacA and Sarèle, MP 27; e.g., Hartenberger et al. 1970; Vianey-Liaud 1976). This basin is partially related with the Sommières basin (NW-SE; Gard, France) which displays well-known fossiliferous localities like Euzet, Fons, Robiac and the Célas sandstones (e.g., Gervais 1848, 1856; Depéret 1917; Roman 1903; Hartenberger et al. 1970). During the instal- lation of a gas pipe, a new locality was discovered East-NorthEast to Alès, at Saint-Privat-des-Vieux (Gard). The fossils come from a dark lenticular layer, about $20 \mathrm{~cm}$ thick, extending a few meters long, rich in organic matter and aquatic snails, overlying a layer of beige to pale brown marly limestone displaying numerous fragments of plants. The dark layer has yielded most of the small vertebrate remains.

One of the interests of this fossil fauna lies in the abundance and quality of the remains of two rodents, Issiodoromys pauffiensis Vianey-Liaud, 1976 and Pseudocricetodon incertus (Schlosser, 1884), resulting from particular taphonomic conditions. Most of small vertebrates come from sedimentation and low transport of owl pellets into a swamp; species of larger size are rare, and they have been carried into the swamp by fluvial input. If taphonomic requirements have been discussed in Bonnet et al. (2011), the fauna remained undescribed. In this paper we describe the whole vertebrate fauna, with more detailed analysis for rodents.

\section{MATERIAL AND METHODS}

\section{DENTAL TERMINOLOGY}

For cricetid rodents, we use the dental nomenclature proposed by Freudenthal et al. (1994: 61); for theridomyids and eomyids, e.g., Comte et al. (2012: 176); for glirids, Vianey-Liaud (1994: 123); for sciurids, Wood \& Wilson (1936: 389, 390); for bats and Lipotyphla, e.g., Van Valen (1966) and Szalay (1969).

\section{MEASUREMENTS}

Measurements have been performed with a Nikon Measuring Microscope (UMR 7207 for carnivores, UMR 5554 for the small mammals and crocodilian egghell fragments).

\section{Material From SAINT-PriVAT-DES-VIEUX}

Collections of Paleontology, Institut des Sciences-de l'Évolution, Montpellier 2 University (ISE-M, UM2).

MATERIAL FROM EHRENSTEIN7 (DECIDUOUS TEETH OF ISSIODOROMYS QUERCYI (SCHLOSSER, 1884))

Collections of the Bayerische Staatssammlung für Paläontologie und Geologie, Munich (BSPG). 
TABLE 1. - Biochronologic position and correlation with the geochronologic timescale (following Van Simayes \& Vandenberghe 2006 and Vandenberghe et al. 2012), of the Oligocene localities considered in this paper. Abbreviations: My, million years; MP, European Mammalian Paleogene standard-level.

\begin{tabular}{|c|c|c|c|c|c|}
\hline \multirow{10}{*}{ 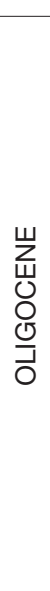 } & & My & MP & Standard localities & Other localities, considered in this paper \\
\hline & \multirow{8}{*}{$\frac{Z}{\mathbb{Z}}$} & & 30 & Coderet & \\
\hline & & -24 & 29 & Rickenbach & \\
\hline & & & $28 \mathrm{~b}$ & Pech-du-Fraysse & Gaimersheim \\
\hline & & -25 & 28 & & Pech-Desse \\
\hline & & 26 & 27 & Boningen & BoujacA, Sarèle, Ehrenstein 7, Mirambueno 1 \\
\hline & & & 26 & Mas-de-Pauffié & St-Privat-des-Vieux, St-Henri/St-André, St-Menoux, \\
\hline & & -27 & $25 b$ & Garouillas & Pareja, Rigal-Jouet 1 \\
\hline & & & $25 a$ & & \\
\hline & 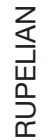 & -28 & 24 & Heimersheim & Glaciations \\
\hline
\end{tabular}

\section{SYSTEMATIC PALEONTOLOGY}

Sub-class LISSAMPHIBIA Haeckel, 1866 Order CAUDATA Scopoli, 1777

Family SALAMANDRIDAE Goldfuss, 1820

\section{cf. Chelotriton Pomel, 1853}

Type species. - Chelotriton paradoxus Pomel, 1853 by monotypy.

Material EXAMINED. - One incomplete trunk vertebra (SPV710).

\section{DESCRIPTION}

The vertebra preserves the centrum, incomplete prezygapophyses and the right rib-bearer. The centrum is opisthocoelous, its condyle being well-ossified. The rib-bearer is bicipital; the two processes are clearly, although not widely, divergent and connected by a bony lamina up to their tips. The anterior zygapophyseal crest is not horizontal; it extends posteroventrally to join the lamina that unites the rib-bearers. The surface of the bone shows an ornamention comprising pits and ridges.

\section{DISCUSSION}

Although the specimen is incomplete, the available characters permit identification below family level. The connection of the anterior zygapophyseal crest to the lamina of the rib-bearer is characteristic of a small assemblage of extinct and living Salamandridae. Among them is Chelotriton (Bailon et al. 2011), the only genus of this assemblage that occurs in the Oligocene of Europe. The overall morphology of the fossil is consistent with Chelotriton; however, the ornamentation of the bone surface appears to be more marked than in the known remains of this genus. Therefore, the referral to Chelotriton cannot be accepted without reservation. Chelotriton was reported only in Europe, from the Middle Eocene (MP 11) to the Late Pliocene (MN 16) (Bailon 1989). It occurs more frequently in the Oligocene and Miocene than in the other levels.

\section{Caudata indet.}

Material examined. - One radius (SPV711), one femur (SPV712), and one incomplete humerus (SPV713). 


\section{DISCUSSION}

The small size and slenderness of these specimens are likely not consistent with the above-described vertebra.

\section{Order ANURA Fischer von Waldheim, 1813 Family Alytidae Fitzinger, 1843}

\author{
Genus Discoglossus Otth, 1837 \\ or Latonia Meyer, 1843 \\ (Fig. 1A-C)
}

Type SPeCies. - Discoglossus pictus Otth, 1837 (by monotypy) or Latonia seyfriedi von Meyer, 1843 (by monotypy).

Material EXAmined. - Four incomplete maxillae (SPV714), one angular (SPV715), two urostyles (SPV716), one scapula (SPV702), one humerus (SPV703), nine ilia (SPV701 and SVP717).

\section{DESCRIPTION}

The ilium bears a dorsal crest and its pars ascendens ends as an elongate ischiatic process. The posterior border of the crest is thickened; the thickened part forms the tuber superius. The angle formed by the pars ascendens and the tuber superius is widely obtuse. The urostyle is provided with two cotyles and a pair of transverse processes. The scapula is short dorsoventrally, more specifically the pars suprascapularis is not elongate dorsoventrally. The incomplete humerus had likely a paraventral crest; the humeral condyle is shifted laterally, whereas the diaphysis was likely comparatively straight. The maxillae are not ornamented and their infraorbital areas are relatively deep. The coronoid process of the angular is short and it is tilted medially; the medial border of the process forms some dorsal tubercles and pits. The bone lacks a paracoronoid process.

\section{Discussion}

Assignment to the Alytidae (formerly Discoglossidae) is supported by the combination of the following features: ischiatic process of the ilium elongated posteriorly, presence of two transverse processes on the urostyle, scapula short dorsoventrally, presence of a paraventral crest on the humerus, infraorbital area of maxillae comparatively deep, and coronoid process of the angular inclined medially.

Within alytids, the presence of a dorsal crest on the ilium and the tuber superius formed by a thickening of the posterior border of this crest are characteristic of the "Discoglossus group". This referral is consistent with the presence of two cotyles on the urostyle and the absence of a clear curvature of the humeral diaphysis.

The "Discoglossus group" includes two extant genera (Discoglossus and Latonia) that are known also in the European Cenozoic. It is generally difficult to discriminate between these two genera, as shown by the fact that the living Latonia nigriventer (Mendelssohn \& Steinitz, 1943) was long assigned to Discoglossus (Biton et al. 2013). Among fossils, the size was often used as one of the main "diagnostic" features. Extinct Latonia are larger than Discoglossus, but the recent referral of $D$. nigriventer to Latonia has shown that the size cannot be significant. Reliable osteological features were listed by $\mathrm{Bi}$ ton et al. (2013); unfortunately, none of these characters is preserved on the specimens from Saint-Privat-des-Vieux. In addition, a peculiar character occurs on the angular of the fossil: the medial part of the coronoid process forms a border bearing some pits and tubercles that face dorsally. Such a feature is observed for the first time. Consequently, the fossil from SaintPrivat-des-Vieux cannot be confidently referred to either Discoglossus or Latonia. Whatever the genus, this frog likely required the permanent presence of fresh water.

The earliest probable Latonia was reported from the earliest Oligocene (MP 21; Rage \& Roček 2003), the referral at genus level of older alytids being questionable. Latonia was frequently reported from the late Cenozoic of Europe (Roček 1994; Roček \& Rage 2000). The earliest confirmed Discoglossus is known from the latest Oligocene (MP 30), although a form close to the genus was recovered from MP 21 (Rage \& Roček 2003). These two genera have never been reported together from the same locality. 
Family RANIDAE Rafinesque, 1814

Genus Pelophylax Fitzinger, 1843

Type SPECIES. - Pelophylax esculentus (Linnaeus, 1758) by original designation.

\section{Pelophylax sp.}

(Fig. 1D, E)

MATERIAL EXAMINED. - Four incomplete maxillae (SPV718), one angular (SPV719), one vertebra (SPV720), one urostyle (SPV721), one humerus (SPV705), six ilia (SPV704 and SPV722).

\section{DESCRIPTION}

The ilia bear a high dorsal crest; the posterior border of the crest is thickened and it forms the tuber superius. This tuber rises rather steeply with regard to the pars ascendens and its anterior limit is clearly marked. On the angular, the coronoid process is almost vertical. The single available vertebra is amphicoelous; it is therefore the $8^{\text {th }}$, i.e. the last presacral vertebra. The urostyle has two circular cotyles, well-distinct from each other. The diaphysis of the humerus was likely straight and the humeral condyle is in line with its axis. The infraorbital area of the maxillae is shallow and not ornamented.

\section{DISCUSSION}

The ilia do not preserve their ischiatic processes; however, the dorsal crest is higher than that of alytids and the posterior border of the tuber superius is closer to the vertical. These features, as well as the nearly vertical orientation of the coronoid process and the axial position of the humeral condyle point to the Ranidae. The amphicoelous condition of the vertebra corroborates this referral since the $8^{\text {th }}$ vertebra of ranids and other ranoids is amphicoelous. The morphology of the urostylar cotyles and the shallowness of the infraorbital area of the maxillae are not diagnostic characters, but they are consistent with the Ranidae.

Within Ranidae, this fossil is referred to the water (or green) frogs, that is to the genus Pelophylax. Mainly, the steep slope of the tuber superius, in lateral view, is a conspicuous characteristic of this genus. In addition, the height of the dorsal crest and the marked anterior limit of the tuber superius support this assignment. Pelophylax, an extant genus, is first reported in the early Oligocene (MP 22) of Germany (Sanchiz et al. 1993). These frogs do not live permanently in fresh water, but they live close to and they often enter it.

\section{Order CHELONII Latreille, 1800}

Chelonian indet.

Material examined. - Five fragments of plates (SPV743).

\section{DisCUSSION}

Some fragments of plates show that turtles were present. However, they cannot be identified.

\section{Order CROCODYLIA Gmelin, 1789}

$$
\text { Crocodylian indet. }
$$

Material eXAmined. - About 200 complete and incomplete, isolated teeth (SPV744 [conical teeth], SPV745 [globular teeth]) and five fragments of skull bones (SPV746).

\section{DESCRIPTION AND DISCUSSION}

Almost all teeth are conical, comparatively elongate and slightly curved lingually. However, rare teeth are short and globular; they come from the posterior portion of the tooth row. The longest tooth reaches $12 \mathrm{~mm}$. Longitudinal striae appear to be present on some teeth. Some specimens bear mesial and distal, non-serrated carinae. Such teeth were often referred to as Diplocynodon Pomel, 1847, an alligatoroid endemic to Europe. Five fragments of skull bones bearing relatively large pits likely belong to the same taxon.

Diplocynodon is known from the early Eocene to the middle Miocene (Delfino \& Smith 2012; Martin \& Gross 2011); it is the most common crocodylian from the Cenozoic of Europe. However, although the specimens from Saint-Privat-des-Vieux are consistent with Diplocynodon, the available material does not permit secure referral at genus level. 


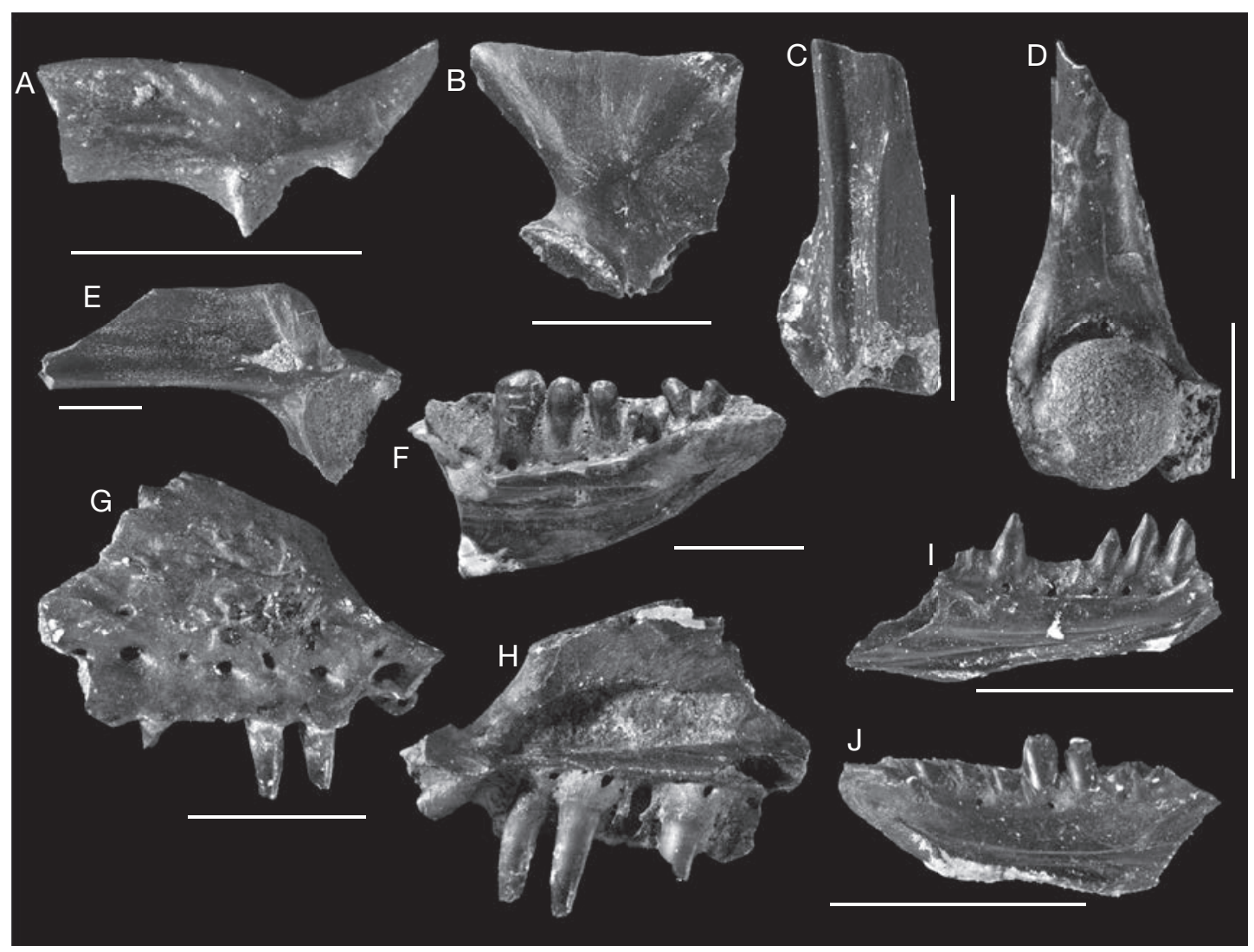

FIG. 1. - Amphibians and lizards from Saint-Privat-des-Vieux (Gard; Lower Chattian, MP 26): A-C, Discoglossus Otth, 1837 or Latonia Meyer, 1843: A, left ilium (SPV701) in lateral view; B, right scapula (SPV702) in lateral view; C, right angulare (SPV715) in dorsal view; D, E, Pelophylax sp.: D, right humerus (SPV705) in ventral view; E, left ilium (SPV704) in lateral view; F, cf. Pseudeumeces Hoffstetter, 1944, left dentary (SPV706) in medial view; G, H, ?Shinisauria indet., right maxilla (SPV709): G, lateral view; H, medial view; I, amphisbaenian A, left dentary (SPV707) in medial view; J, amphisbaenian B, right dentary (SPV708) in medial view. Scale bars: 3 mm.

Genus Krokolithes Hirsch, 1985

TYPE SPECIES. — Krokolithes wilsoni Hirsch, 1985.

\section{Krokolithes sp.}

Material EXAMined. - Seven small fragments (from 1 to $\left.3 \mathrm{~mm}^{2}\right)$; thickness $=0.33,0.35,0.38,0.39,0.40$, 0.42, $0.45 \mathrm{~mm}$; SPV750.

\section{DESCRIPTION (Fig. 3A)}

Two fragments of eggshells from this locality are figured in Bonnet et al. (2011: pl. II, figs B, C).
The size of fragments does not allow to infer the shape of the egg. Like in Krokolithes wilsoni Hirsch, 1985 the outer surface is rough, and shows erosion craters and circular pore openings (diameter $=0.09$ and $0.13 \mathrm{~mm}$ ) with stepped erosion rings; therefore there are low blunt anastomosed and irregular ridges. Basal knobs are well distinct on two fragments and worn on the others. Thus, the radiating wedges are visible. The units are relatively wide (as wide as high, or wider than high) and display the typical wedge pattern of crocodylian eggshells. There are deep insterstices between the units. The fragments are thinner than in the Eocene $K$. wilsoni Hirsch, 1985 and much more than the Miocene crocodylian indet. (Hirsch \& Kohring 1992). 


\section{DisCUSSION}

The small size of our fragments does not allow to make a precise identification. The general ultrastructure - coarse wedges and tabular crystalline structure -, the figures of erosion, the arrangement of units and their width allow an assignment to Krokolithes. This ootaxon was formerly recovered from the Eocene of North America (Hirsch 1985) and from the Eocene and Miocene of Germany. Kohring \& Hirsch (1996) suggested that at least part of the material assigned to Krokolithes may represent eggs of Diplocynodon.

\section{Order SQUAMATA Oppel, 1811 'Lacertilians' \\ Family LACERTIDAE Bonaparte, 1831}

Genus Lacerta s.1. Linnaeus, 1758

TYPE SPECIES. — Lacerta agilis Linnaeus, 1758.

\section{Lacerta cf. filholi Augé, 1988}

Material eXAmined. - Six incomplete maxillae (SPV723), five incomplete dentaries (SPV724), four fragments bearing teeth (SPV725).

\section{DESCRIPTION}

The teeth are all pleurodont; the anterior ones have a single cuspid, others (probably from the midsection of the tooth row) are bicuspid, whereas the larger teeth, i.e. from the posterior section, have three cuspids. Well-marked vertical striae occur on the apices. None of the teeth is amblyodont (i.e. "molariform"). On the maxillae, the anteriormost teeth are acute and recurved.

\section{DisCUSSION}

The combination of mono-, bi- and tricuspid teeth in a single tooth row, presence of anterior recurved maxillary teeth and the striation of apices point to Lacerta s.l. filholi. This small lizard is frequent in the Oligocene of western Europe. However, the preserved parts of the maxillae do not bear osteoderms. Therefore, although this absence may be only of ontogenetic nature, assignment to this species cannot be accepted without reservation. Lacerta s.l. filholi was reported from MP 21 to MN 2 (Augé 2005; Augé \& Smith 2009).

\section{cf. Pseudeumeces Hoffstetter, 1944}

(Fig. 1F)

TYPE SPECIES. — Pseudeumeces cadurcensis (Filhol, 1877).

MATERIAL EXAMINED. - One anterior part of dentary (SPV706).

\section{DESCRIPTION}

The dentary is deep and its subdental shelf (sensu Rage \& Augé 2010) markedly thickens anteriorly. Teeth are pleurodont; the most anterior ones are not enlarged but the last tooth of the preserved row is amblyodont, i.e. it is larger than normal teeth. The enlargement, from the most anterior to the more posterior teeth is progressive. The apices are round and devoid of cuspids. Striae are present on the apices but they are weak on the largest tooth.

\section{DisCUSSION}

Several lizard taxa with amblyodont teeth, or showing tendency toward amblyodonty, are known in the European Cenozoic, mainly from the Oligocene (Rage 1987, Augé 2005). The amblyodont condition is weak in Mediolacerta roceki Augé, 2005 (MP 23-MP 30) and is very prominent in Dracaenosaurus croizeti Gervais, 1848-52 (MP 28-MP 30). Morphologically, between these two species occur the intermediate taxa Amblyolacerta Roček, 1884 and Ligerosaurus Augé, Bailon \& Malfay, 2003 from the Miocene and Pseudeumeces from the Oligocene. The fossil from Saint-Privat-des-Vieux may be distinguished from Amblyolacerta and Mediolacerta Augé, 2005 by its stronger amblyodonty. It differs from Ligerosaurus in having a subdental shelf that grows clearly thinner posteriorly and a facet for contact with the splenial that does not reach the anterior part of the bone. In contrast, the fossil does not show any difference with Pseudeumeces and only the incomplete nature of the specimen prevents confident referral to this genus. Pseudeumeces includes a single species, P. cadurcensis (Filhol, 1877), that is known from MP 25 to MP 28. Apparently, amblyodont lizards fed at least partly on shelled mollusks (gastropods). 


\section{Amblyodont lacertid indet.}

MATERIAL EXAMINED. - Two fragments bearing teeth (SPV726).

\section{DisCUSSION}

Teeth are weakly amblyodont, which is reminiscent of a lizard such as Mediolacerta. In view of the very fragmentary nature of the remains, identification at genus level is not possible. However, these fragments are evidence of a distinct taxon.

Family ANGUIDAE Gray, 1825

Subfamily ANGUiNAE Gray, 1825

Genus Ophisaurus s.l. Daudin, 1803

TYPE SPECIES. — Ophisaurus ventralis (Linnaeus, 1766) by monotypy.

MATERIAL EXAMINED. - Six trunk (SPV727) and 15 caudal (SPV728) vertebrae, and about 140 osteoderms (SPV729).

\section{DESCRIPTION}

The trunk vertebrae are depressed as well as are their cotyles and condyles. The ventral surface of the centrum is almost flat and it clearly widens anteriorly. The caudal vertebrae are more elongate than those from the trunk and they bear haemapophyses fused to the centrum. Most caudals have an autotomous septum. The osteoderms are approximately rectangular; their external face is made up of an anterior smooth, gliding surface and a posterior larger, ornamented part. The ornamentation is comprised of ridges and grooves; a low longitudinal keel occurs in the ornamented part. The internal face is entirely smooth, but two small foramina are present.

\section{DisCUSSION}

The morphology of these vertebrae and osteoderms is quite typical of the Anguinae, a taxon that includes elongate, limbless forms. The vertebral centrum, whose lateral borders markedly diverge anteriorly, shows that the vertebrae do not belong to Anguis Linnaeus, 1758. The other genera belonging to the Anguinae may be securely distinguished only on the basis of cranial bones; they are often collectively referred to as "Ophisaurus s.l." Therefore, the anguine from Saint-Privat-des-Vieux is referred to the latter assemblage, without further identification. Anguinae occur in most localities from the European Cenozoic; they were all terrestrial.

\section{Sub-order SHINISAURIA Conrad, 2008}

?SHINISAURIA indet.

(Fig. 1G, H)

MATERial EXAmined. - One incomplete maxilla (SPV709) and one fragment of dentary (SPV730).

\section{DESCRIPTION}

The maxilla preserves only its anterior part. It is deep and provided with a strong premaxillary process; on the medial side of the latter process, remains the base of what is likely a broken off septomaxillary process. The lateral surface is ornamented by ridges and grooves. On the medial face, a marked recess is located dorsal to the supradental shelf; it is clearly limited anteriorly. Teeth are borne by a single, inclined surface made up by the alveolar surface and the subdental table (sensu Rage \& Augé 2010) that join as a unique, oblique plane. The supradental shelf is thin and there is no sulcus dentalis. The maxilla preserves two teeth that are long and almost straight. Their distal parts are slightly recurved; their tips are broken away. The bases of the teeth are slightly expanded medially and they show weak vertical striae, but plicidentine is lacking. Small resorption pits are present. On the fragment of dentary, the only preserved tooth is similar to those of the maxilla.

\section{DISCUSSION}

The alveolar surface and the subdental table form a single surface, without any angulation between them. This characteristic occurs only in anguimorphs, although not in all. The morphology of the teeth (long and whose only the distal part is recurved) appears to be known only in Merkurosaurus Klembara, 2008, a shinisaurian anguimorph reported from the Oligocene and Miocene of Europe. In 
addition to tooth morphology, the characters of the maxilla are consistent with this genus. Merkurosaurus belongs to Shinisauria (Klembara 2008; Conrad et al. 2011), a clade that includes a single extant species (Shinisaurus crocodilurus Ahl, 1930) that occurs in China and Vietnam. Merkurosaurus is more precisely known from the latest Oligocene of Germany (MP 30; Böhme 2008) and the early Miocene of Germany (MN 2; Čerňanský et al. in press) and of the Czech Republic (MN 3; Klembara 2008). A case could be made for inclusion of a younger anguimorph from the middle Miocene (MN 5) of France to Merkurosaurus. The latter fossil has long teeth and it was reported as Anguimorpha incertae sedis (Augé \& Rage 2000). Unfortunately, the only available specimen (a fragment of dentary) is not sufficient for an assignment at genus level. Similarly, on the basis of the available material, the fossils from Saint-Privat-des-Vieux cannot be referred confidently to Merkurosaurus and even assignment to shinisaurs cannot be accepted without reservation. However, should it prove correct that the specimens from Saint-Privat-des-Vieux belong to a shinisaur, then these fossils represent the earliest member of the clade in Europe.

\section{Sub-order AMPHISBAENIA Gray, 1844 Family indet.}

\section{Amphisbaenian A}

Material EXAMINED. - Two fragmentary dentaries (SPV707 and SPV731).

\section{DESCRIPTION AND DISCUSSION (Fig. 1I)}

The two fragments bear pleurodont, conical but slightly labiolingually compressed teeth whose apices are comparatively pointed and weakly recurved. An intramandibular septum was present in the Meckelian groove, but only its most anterior part is preserved in the two specimens. On the medial face, the anterior extremity of the facet for articulation with postdentary bones is rounded. Similar dentaries are relatively frequent in the Cenozoic of Europe; they were generally assigned to the Amphisbaenidae and regarded close to, or referred to the extant European genus Blanus Wagler, 1830 (this genus is today allocated to its own family, Blanidae; Kearney 2003). Referral at family level of the two fragments from Saint-Privat-des-Vieux is not possible. Their teeth are similar to those of the amphisbaenian from Le Garouillas (MP 25) that was assigned to the Amphisbaenidae s.l., i.e. Blanidae included (Augé \& Rage 1995: fig. 6), but teeth were apparently more numerous on the specimens from Saint-Privat-des-Vieux.

\section{Amphisbaenian B}

Material eXAMINED. - One incomplete dentary (SPV708).

\section{DESCRIPTION AND DisCUSSION (Fig. 1J)}

All teeth are incomplete. However, their shaft is cylindrical, not compressed. Anteriorly, the angle made by the ventral border of the bone is more marked than in amphisbaenian A. On the medial face, the anterior extremity of the facet for postdentary bones forms an acute angle and is located more posteriorly than in amphisbaenian $\mathrm{A}$. The posterior part of the bone is broken away, therefore the presence of an intramandibular septum cannot be checked. The morphology of the teeth might fall within the range of variation known in Palaeoblanus tobieni Schleich, 1988. The latter taxon was reported from the early and middle Miocene (MN 3 to MN 5) of Germany (Schleich 1988; Böhme 2010), but the poor preservation of the specimen from Saint-Privat-des-Vieux prevents any precise identification.

Amphisbaenians indet.

MATERIAL EXAMINED. - One premaxilla (SPV734) and 11 trunk vertebrae (SPV732 and SPV733).

\section{DisCUSSION}

Several vertebrae are known from Saint-Privat-desVieux. Two morphological types may be distinguished, which confirms the presence of two distinct 
amphisbaenian taxa. Five vertebrae (SPV733) have a low neural canal and in six vertebrae (SPV732) the neural canal is higher. However, the proper association of a vertebral morphological type with one of the dentary morphologies (amphisbaenian A or B) cannot be made. A premaxillary has a large sagittal tooth, which is an autapomorphy of amphisbaenians; but as for vertebrae it is not possible to refer it to either amphisbaenian $\mathrm{A}$ or $\mathrm{B}$.

\section{COMMENTS}

Amphisbaenians are fossorial elongate lizards living in dry, or comparatively dry environments. They make tunnels in soft or hard soils. Some, but not all, may enter anthills or termitaria, in order to feed on the insects living there (Riley et al. 1986).

\section{Lizard indet.}

Material eXAMined. - One incomplete parietal (SPV735) and one incomplete frontal (SPV736).

\section{COMMENTS}

The parietal is characterized by the absence of ornamentation and of any trace of epidermal scales. This is quite unusual in lizards. The frontal displays a weak ornamentation and it shows limits of epidermal scutes. However, none of the characters is sufficiently significant for assignment within lizards.

Sub-order SERPENTES Linnaeus, 1758

Family TropidopHIIDAE Cope, 1894

\section{Genus Platyspondylia Rage, 1974}

Type species. - Platyspondylia lepta Rage, 1974 by monotypy.

\section{Platyspondylia sp.}

(Fig. 2)

Material EXAMINED. - 11 trunk (SPV737) and four caudal (SPV738 to SPV741) vertebrae.

\section{DESCRIPTION}

All vertebrae are small (length of centrum $<3 \mathrm{~mm}$ ). Trunk vertebrae are mainly characterized by their markedly depressed neural arch and by the presence of an obtuse posterior median notch. The neural spine is developed, but not high, and it does not reach the zygosphene anteriorly. The interzygapophyseal constriction is well expressed. The centrum does not markedly widen anteriorly. The most significant features occur on caudal vertebrae. Aside from ventral structures, the overall morphology, and more specifically the neural spine and neural arch of caudal vertebrae are similar to those of the trunk region. A vertebra (SPV738) from the anterior portion of the caudal region bears a hypapophysis; although damaged, it appears clearly that its extremity is hollowed by a shallow sagittal groove (Fig. 2A-C). Another caudal (SPV739) is provided with a haemal keel whose posterior part has a ventral groove (Fig. 2D-F). It is regarded as a vertebra from the posterior part of the anterior portion of the caudal region. SPV740 possesses the bases of broken off haemapophyses (Fig. 2G-I); it comes from the mid-caudal region. The position within the caudal region of a vertebra (SPV741), the ventral structures of which are broken off, cannot be determined.

\section{DisCUSSION}

Trunk vertebrae do not clearly differ from those of Platyspondylia lepta Rage, 1974 (MP 28-MP 30). However, in the latter the anterior border of the neural spine is vertical whereas it is inclined posteriorly on the specimens from Saint-Privat-des-Vieux. This is apparently a minor morphological difference, but stratigraphically the inclined border appears to be permanent from MP 22 to MP 26 (it being understood that no fauna including Platyspondylia is known from MP 27) (Szyndlar \& Rage 2003), whereas the vertical border occurs from MP 28 to MP 30, which may be significant. Augé \& Rage (1995) suggested that this form with an inclined anterior border may represent a species distinct from $P$. lepta.

At higher taxonomic level, the fossils from SaintPrivat-des-Vieux afford an important information. The sequence of ventral structures observed on caudal vertebrae characterizes the Tropidophiinae, or Tropidophiidae s.s. (Szyndlar et al. 2008). Up to now, the 
only known caudals of Platyspondylia were provided with paired haemapophyses, i.e. the condition known in vertebrae from the mid-section of the caudal region of Tropidophiidae s.s. but also in the entire caudal region of most snakes. The fossils from Saint-Privatdes-Vieux show that haemapophyses are absent in the anterior portion of the caudal region of Platyspondylia. In this portion, the ventral structure is azygous; it is either a hypapophysis, anteriorly, or a haemal keel, posteriorly. Only the available vertebra from the midcaudal region bears haemapophyses. This sequence of ventral structures in the caudal region (hypapophysis, haemal keel, haemapophyses) is known only in the Tropidophiidae s.s. Unfortunately, no vertebra from Saint-Privat-des-Vieux represents the third portion of the caudal region. Nevertheless, the available caudal vertebrae from Saint-Privat-des-Vieux confirm the referral of Platyspondylia to the Tropidophiidae s.s., an assignment that was questioned by Holman $\&$ Harrison (1998). Today, tropidophiids are restricted to northern South America, Central America and Carribean islands. However, representatives of the family were recorded in Europe from the early Eocene to the early Miocene.

\section{Booid indet.}

MATERIAL EXAMINED. — Five trunk vertebrae (SPV742).

\section{DisCUSSION}

This small snake, however larger than Platyspondylia, is represented by poorly preserved specimens. The neural spine is longer anteroposteriorly than in Platyspondylia and the neural arch was likely more vaulted. The fossils belong to the booid grade but further referral is not possible.

Class MAMMALIA Linnaeus, 1758 Infra-class MARSUPIALIA Illiger, 1811

Family DidELPHIDAE Gray, 1821

Genus Peratherium Aymard, 1850

TyPe SPECIES. - Peratherium elegans (Aymard, 1846) by subsequent designation of Aymard (1850).
Peratherium cf. elegans (de Blainville, 1840)

Material eXAMined. - Four fragments of upper M12-3 ? (three lingual worn fragments, SPV790-792, one labial fragment weakly worn, SPV793).

\section{DESCRIPTION}

When directly compared, the size of the teeth is the same as in Peratherium elegans from Mas-de-Pauffié. But, as the teeth are rare and incomplete, it is difficult to determine them at the species level. On the only available labial fragment, the stylar cusp C is a little more reduced than on the few teeth from Mas-de-Pauffié. On the base of the paracone, the stylar surface of the enamel bears two weak crestules linguo-labially oriented. The styles are less sharp than in P. elegans.

\section{Clade EUTHERIA Gill, 1872 \\ Order LIPOTYPHLA Haeckel, 1866 \\ Family TALPIDAE Gray, 1821}

Genus cf. Geotrypus Pomel, 1848

(Fig. 3B)

TYPE SPECIES. - Geotrypus acutidentatus de Blainville, 1840 by subsequent designation of de Blainville (1840).

MATERIAL EXAMINED. - SPV800-802: one complete lower molar $(\mathrm{m} 1$ ?: $\mathrm{L}=2.16$, Ltrig. $=1.09$, Ltal. $=1.08$, wtrig. $=1.35$, wtal. $=1.58)$, and a broken lower molar $(\mathrm{m} 2$ ?), both weakly worn out and one lower premolar.

\section{DESCRIPTION}

The complete molar is probably an $\mathrm{m} 1$, the talonid being wider than the trigonid. The other trigonid being still wider, it would be that of an $\mathrm{m} 2$. Cuspids are high. The hypoconid is as high as the protoconid. The paraconid is twice as high as the metaconid, and it has the same height as the entoconid. Seen in lingual profile, the metaconid is almost cylindrical, sharper only at the top. The lingual profile of the entoconid is more conical than the metaconid, but with a relatively narrow base and an acute angle at the top. The postcristid is directly and transversely connected with the entoconid. There is no preentocristid. A strong entostylid can be seen near the end of the very low posterior cingulum. It then 

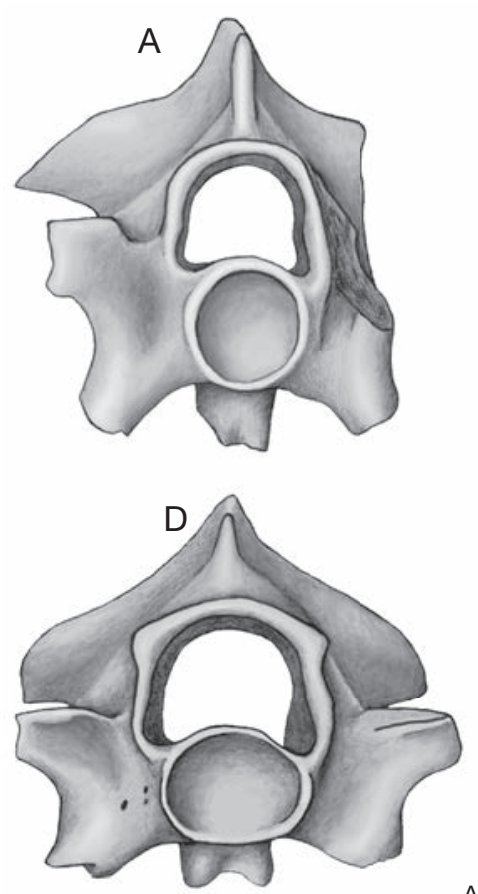

$A, B, D, E, G, H$

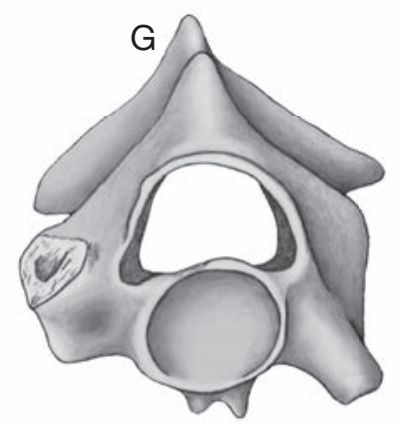

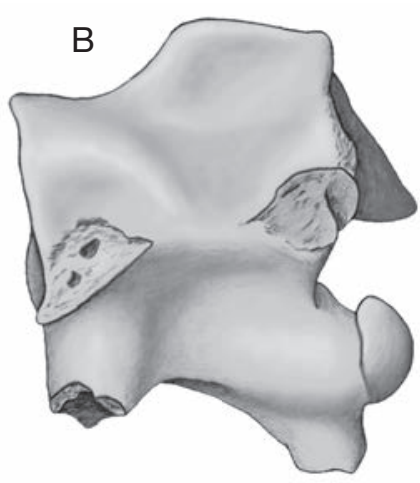
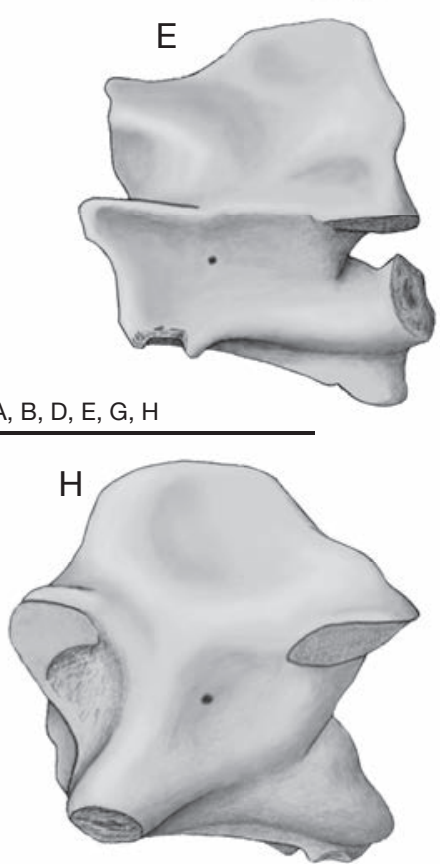

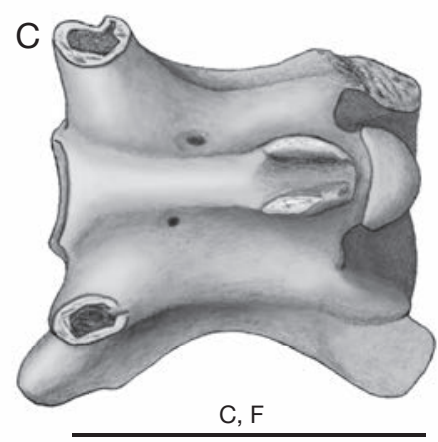

$\mathrm{F}$
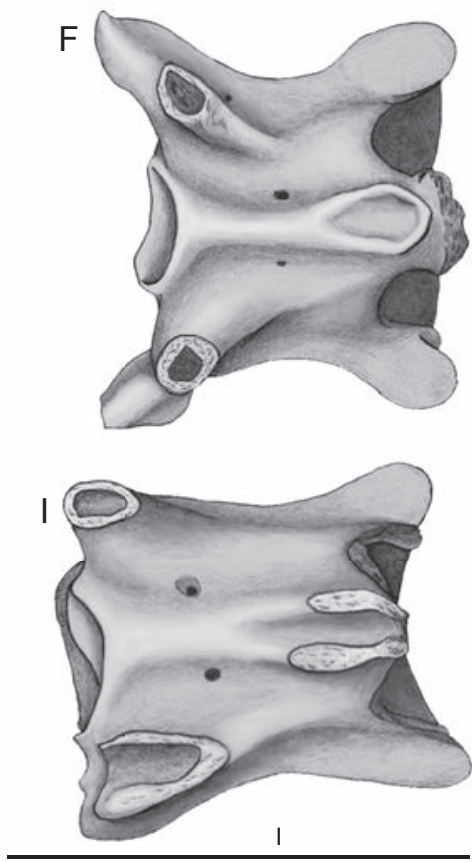

FIG. 2 - Serpentes from Saint-Privat-des-Vieux (Gard; Lower Chattian, MP 26), Platyspondylia sp.: A-C, anterior caudal vertebra (SPV738): A, anterior view; B, left lateral view; C, ventral view; D-F: caudal vertebra (SPV739) from the anterior caudal region, but posterior to SPV738: D, anterior view; E, left lateral view; F, ventral view; G-I: mid-caudal vertebra (SPV740); G, in anterior view; H, left lateral view; I, ventral view. Scale bars: $2 \mathrm{~mm}$.

extends to the lingual surface of the tooth more or less continuously, by a weak cingular bulge dotted with more or less distant vertical crestules, to join the anterior cingulid. At the lingual base of the crown the collar is rectilinear.

The anterior cingulid extends labially and disappears at the base of the protoconid. Labially a weak and very low cingulum limits the base of the hypoflexid; it does not extend to the base of the hypoconid.

\section{DISCUSSION}

These specimens show similarities with Geotrypus (cusps very slender, somewhat lingually oblique ridge joining the base of the posterior trigonid wall, entocristid reduced or absent, anterior cingulum developed; Crochet 1995). However, a number of differences prevent its attribution with certainty to that genus. The lingual cusps are more slender than those of Geotrypus cf. acutidentatus (de Blainville, 1840) 
from Le Garouillas (Lot, Quercy, MP 25). The teeth from Saint-Privat-des-Vieux differ from those of this species and also from Geotrypus antiquus (de Blainville, 1840) from Pech du Fraysse (MP 28) by their larger size and especially their width. They also differ from these two species in having longer cingulid, smaller parastylid and stronger entostylid, a small difference in height between protoconid and hypoconid and the development of a very low and discontinuous labial cingulid. The lingual base of the crown is in the same vertical plane while it is concave at the opening of the trigonid in $G$. antiquus. It shares with these two species the well cuspidate paraconid, the high labial elongation of the anterior cingulid, and with $G$. cf. acutidentatus the absence of entocristid. It differs from the type of Myxomygale (Filhol, 1890) by the absence of entocristid and metastylid, and the crista obliqua ending less lingually.

Order CHIROPTERA Blumenbach, 1779 Family MOLOSSIDAE Gill, 1872

Genus Cuvierimops Legendre \& Sigé, 1983

TyPe SPECIES. - Cuvierimops parisiensis (Cuvier in Pictet, 1844) by monotypy.

\section{Cuvierimops sp.}

MATERIAL AND MEASUREMENTS (MM). - One left m2 $(\mathrm{L}=1.75, \mathrm{w}=1.29$, talonid $=$ trigonid $)$, one left $\mathrm{m} 3$ $(\mathrm{L}=1.58$, wtrig. $=1.15$, wtal. $=0.97)$, one fragment of left mandible bearing $\mathrm{p} 4-\mathrm{m} 1$ ( $\mathrm{p} 4: \mathrm{L}=? 1.09, \mathrm{w}=0.81$, $\mathrm{m} 1: \mathrm{L}=1.62, \mathrm{w}=1.00)$; one right $\mathrm{C}(\mathrm{L}=1.27, \mathrm{w}=$ $1.06, \mathrm{H}=2.04)$, one left P4, one left M1 (L1, at the paracone-metacone level $=1.79, \mathrm{~L} 2$, at the hypocone level $=1.23, \mathrm{w}=2.15)$, two right $\mathrm{M} 2$ (L1-broken-, L2 = $1.39, \mathrm{w}=2.33, \mathrm{~L} 1=1.74, \mathrm{~L} 2=1.33 ; \mathrm{H}=2.15)$, one posterior fragment of $\mathrm{M} 3$.

\section{DESCRIPTION (Fig. 3C-I)}

Size greater than in Cuvierimops sp. from Le Garouillas (Sigé 1995); dental features more advanced than in the latter (myotodonty, hypocone with a continuous edge from the postprotocrista to the posterior cingulum). It probably represents a new species.

\section{Lower teeth}

All morphological elements of the premolar (p4) are not visible because this tooth is set in a fragment of dentary. Hence its talonid is fitted under the front part of the $\mathrm{m} 1$. The peripheral cingulum is well marked, except on the lingual side where it is partially offset by wear. The protoconid is high. Two lingual cuspids are visible, although they are worn. The anterior cuspid, at the anterior lingual base of the protoconid, is a swelling of the lingual cingulum which also bears a bulge (metaconid?) at the contact with $\mathrm{m} 1$. The talonid is about $1 / 4$ of the length of the $\mathrm{p} 4$. Two out of three molars $(\mathrm{m} 2$ and $\mathrm{m} 3$ ) are myotodont, a doubt remains for the third one, the $\mathrm{m} 1$ (SPV810), which is too worn out posteriorly; in addition to the direct connection between hypoconid and entoconid, the $\mathrm{m} 2$ shows a small low connection with the hypoconulid, this cuspid being, however, reduced. The third molar is labially damaged.

\section{Upper teeth}

Canine size and P4 structure are comparable to those of Cuvierimops from Le Garouillas (Fig. 3F; Sigé 1995: pl. 1, fig. 10). Upper molars are slightly larger than that of the Le Garouillas species. The presence of lingual and posterior cinguli is constant. The lingual side of the crown appears wider and higher than that of the teeth from Le Garouillas (see profiles; Fig. 3H-I). A cutting edge develops there, and continues on M2 from the postprotocrista to the posterior cingulum, through the crista obliqua running along the hypocone and its lingual slope. This makes this cusp losing the conical shape seen on the other species of Cuvierimops. This edge is also found on M1, but it is short. The posterior fragment of M3 is similar to M3 from Le Garouillas (Sigé 1995: fig. 14) with a little more compressed metacone.

\section{DisCUSSION}

The small population of bats from Saint-Privat-desVieux clearly fits with the Molossidae, and more precisely, it can be referred to the genus Cuvierimops. This is indicated in particular by a well developed hypocone, forming a well characterized lobe, a deep ectoloph, and valleys narrow and pinched, mesostyle and parastyle rounded. 

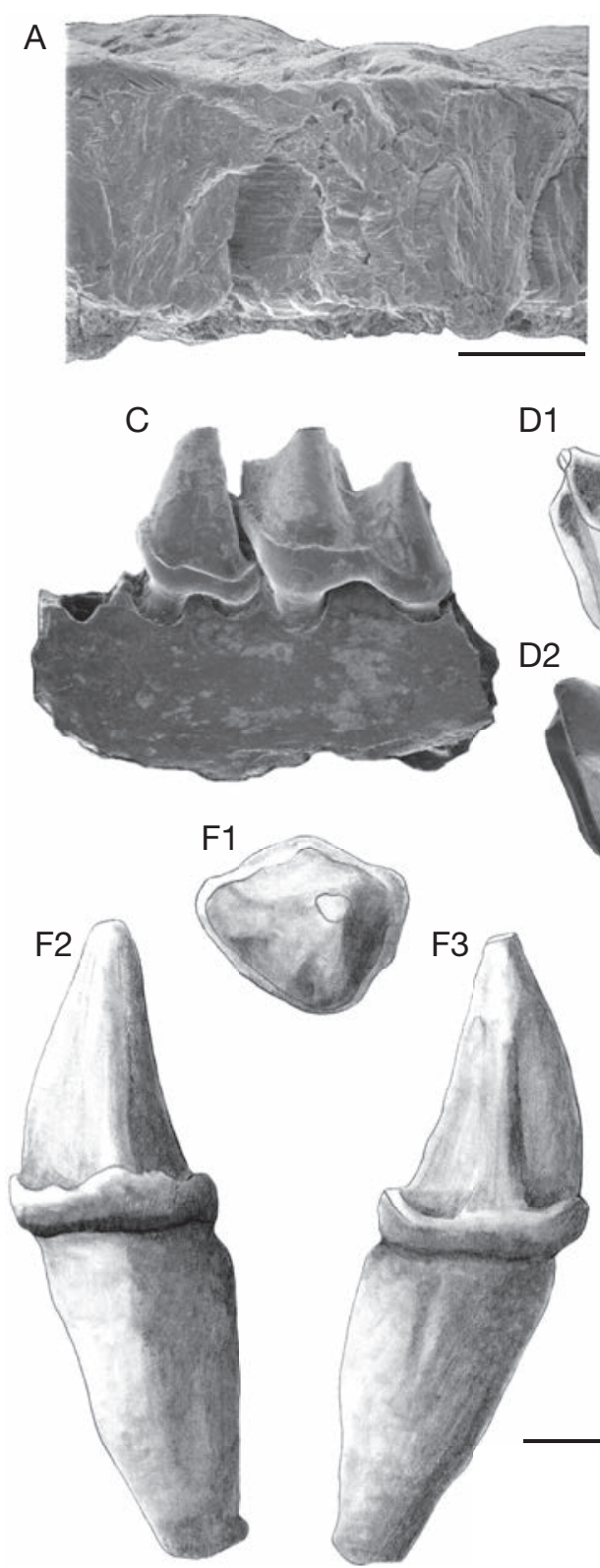

D1

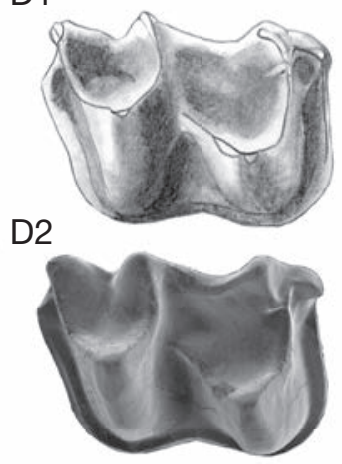

B

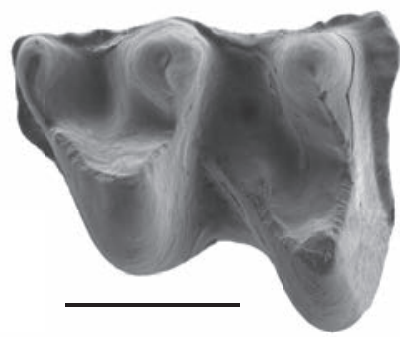

D3

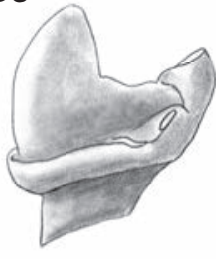

E1

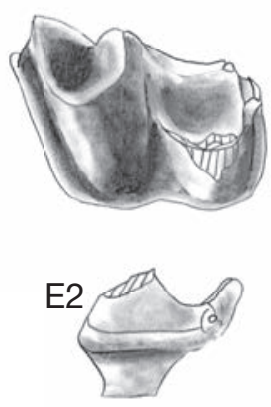

11

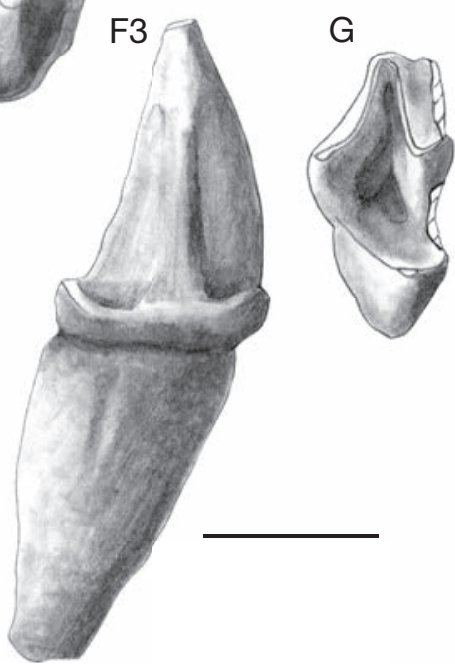

$\mathrm{H} 1$
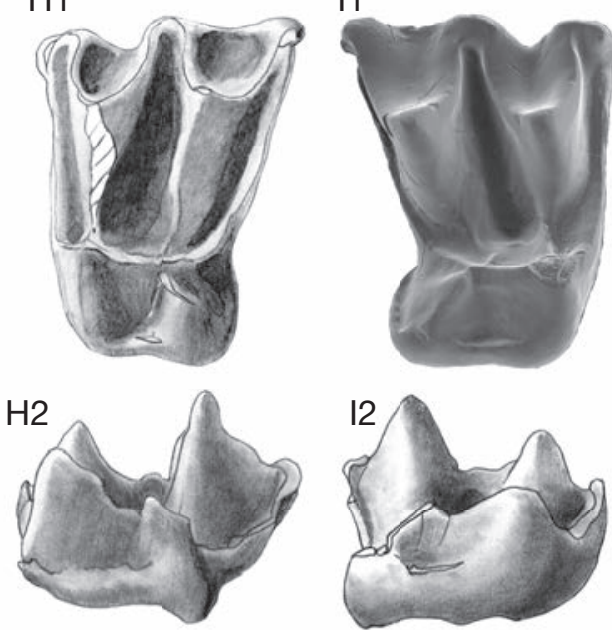

FIG. 3. - Saint-Privat-des-Vieux (Gard, Lower Chattian, MP 26): A, SEM view of a fragment of Krokolithes sp. SPV750; B-H teeth of mammals: B, cf. Geotrypus sp. SPV800, left m1, occlusal view; C-I, Cuvierimops sp.: C, SPV810, left p4-m1, labial view; D, SPV814, left m3: D1, occlusal view, D2, distal view; E, SPV812, left m2: E1, occlusal view, drawing, E2, occlusal view SEM, E3, distal view; F, SPV815, right upper canine: F1, occlusal view, F2, lingual view, F3, labial view; G, SPV820, right M3, occlusal view; H, SPV816, left M1: H1, occlusal view, H2, lingual view; I, SPV817, right M2: I1, occlusal view, I2, lingual view. Scale bars: A, 167 m; B-I2, 1 mm.

However, as our specimens show more advanced characters, they are different from Cuvierimops from Le Garouillas (Sigé 1995). These differen- cies mainly concern myotodonty - generalized on lower teeth-, pinched ectoloph or development of the crista obliqua on hypocone, elevation of this 
hypocone relative to protocone and elongation of lingual edge of the crown. These teeth most likely belong to a new species, not named here given the small number of specimens.

\section{Order RODENTIA Bowdich, 1821}

\section{Family THERIDOMYIDAE Alston, 1876}

TYPE LOCALITY. - The locality of Saint-Privat-des-Vieux has yielded remains of two species of Theridomyidae, allocated to the two subfamilies Theridomyinae (Protechimys major Schlosser, 1884) and Issiodoromyinae (Issiodoromys pauffiensis Vianey-Liaud, 1976). Issiodoromys is very abundant (388 teeth, and postcranial elements) while Protechimys Schlosser, 1884 is much less represented (20 teeth).

\section{Subfamily IssiodOROMYINAE Lavocat, 1951}

\section{Genus Issiodoromys Bravard in Gervais, 1848}

TYPE SPECIES. - Issiodoromys pseudanaema Gervais, 1848 by monotypy.

\section{Issiodoromys pauffiensis Vianey-Liaud, 1976}

HOLOTYPE. - Left dentary with p4-m3, MPF-1 (VianeyLiaud 1976)); coll. UM2.

TyPe LOCALITY. — Mas-de-Pauffié, Lot, Quercy, MP 26 (Chattian).

EMENDED DiAGNOSIS. - (Completing Vianey-Liaud 1976: 55 and Schmidt-Kittler \& Vianey-Liaud 1987): Evolutionary stage intermediate between I. minor (Schlosser, 1884) and I. quercyi (Schlosser, 1884). Cement rarely present at the bottom of sinus and sinusid. Horizontal upper masseteric crest stronger than in I. minor, especially in its posterior part.

Differs from I. minor by the more elongated anterior lobe of $\mathrm{dp} 4$, including two well-developed oblique ridges, mesially to the mesolophid (Ldp4 of I. pauffiensis from Mas-de-Pauffié $=2.71 \mathrm{~mm}$ to $3.01 \mathrm{~mm}$ ); antesinusid generally absent on molars, anteroconid reduced to a weak vertical ridge when present, and in some specimens preceded by a small additional inflection of the crown on dp4; enamel cover thinner; simplified occlusal patterns in some individuals.
Differs from I. quercyi by its smaller size and relatively frequent remnants of the antesinusid-anteroconid on molars.

Differs from I. limognensis Schmidt-Kittler \& VianeyLiaud, 1987, in having the anterior lobe of dp4 less stretched, including less pronounced antesinusids (Ldp4 of I. limognensis from Pech-Desse $=2.96 \mathrm{~mm}$ to $3.67 \mathrm{~mm}$ ), cement limited to the bottom of sinussinusid when present, whereas it reaches the occlusal surface - including teeth slightly to moderately worn in I. limognensis.

MATERIAL EXAMINED. - 29 DP4 (SPV200-228), 40 P4 (SPV229-266), 113 M1-2 (SPV267-389), 26 M3 (SPV390-414); 29 dp 4 (SPV415-442), 21 p4 (SPV443463), 101 m1-2 (SPV464-564), 23 m3 SPV565-589).

MEASUREMENTS. - To the variations in size between the first and second molars (the first being generally smaller than the second) must be added those due to effects of wear on the occlusal surface orientation of hypsodont teeth (Vianey-Liaud et al. 1995: 274, fig. 12), and finally those due to individual variability. The size variations are expressed by the Pearson coefficient: $\mathrm{v}=100 \mathrm{Sd} /$ Lmoy (Table 2). The low size variability observed at Saint-Privat-des-Vieux reinforces the hypothesis on the taphonomy of the fossil assemblage from this locality (Bonnet et al. 2011: 12).

\section{DESCRIPTION}

\section{Lower teeth}

dp4 (Fig. 4). The morphology of dp4 posterior lobe is constant, while some variations are observed in the anterior lobe. This is actually the part of $\mathrm{dp} 4$ that most changes during the evolution of the lineage, extending mesially the abrading surface of the tooth row. All dp4 show 2-3 oblique ridges between the mesolophid and the prelobe tip. The protoconid is split by a small labial notch, already sketched in populations of $I$. minor and present in the type population of $I$. pauffiensis (e.g., Schmidt-Kittler et al. 1997: 385, fig. 7; Vianey-Liaud et al. 1995: 267, fig. 5). The elongated central cuspid, which occupies the mesolophid position, runs obliquely towards the anterior arm of the protoconid to which it may be connected or not. Once upon 20 well preserved teeth, this central cusp reaches the tip of the prelobe. In all other cases, it is preceded by two oblique crestids parallel to it. The first is usually reduced to a small cusp. A continuous cingulid, as high as other ridges, follows the outline of the anterior lobe of teeth from the front flank of the 
TABLE 2. - Measurements of Issiodoromys pauffiensis Vianey-Liaud, 1976 from Saint-Privat-des-Vieux, compared to that (for M1-2 and $\mathrm{m} 1-2$ ) of $I$. pauffiensis from Mas-de-Pauffié, and m1-2 of $I$. quercyi from Ehrenstein7. Abbreviations: Sd, standard deviation; antcd, number of $\mathrm{m} 2$ with anteroconid present.

\begin{tabular}{lcccccccccc}
\hline \multicolumn{1}{l}{ lssiodoromys pauffiensis, Saint-Privat-des-Vieux } & \multicolumn{10}{l}{} \\
\hline & $\mathbf{N}$ & $\mathbf{L}$ min & $\mathbf{L}$ max & $\mathbf{L}$ mean & $\mathbf{v}$ & Sd & w min & w max & w mean & Sd \\
\hline dp4 & 20 & 2.81 & 3.1 & 2.94 & 2.99 & 0.088 & 1.03 & 1.46 & 1.31 & 0.115 \\
p4 & 17 & 1.51 & 1.91 & 1.74 & 6.37 & 0.111 & 0.85 & 1.59 & 1.32 & 0.211 \\
m1-2 & 96 & 1.72 & 2.48 & 2.07 & 7.53 & 0.156 & 1.03 & 2.11 & 1.49 & 0.227 \\
m3 & 12 & 1.79 & 2.19 & 1.99 & 6.22 & 0.124 & 1.19 & 1.31 & 1.48 & 0.176 \\
DP4 & 25 & 2.29 & 2.64 & 2.40 & 3.48 & 0.084 & 1 & 1.51 & 1.32 & 0.138 \\
P4 & 28 & 1.59 & 1.99 & 1.72 & 6.06 & 0.104 & 0.74 & 2.15 & 1.42 & 0.380 \\
M1-2 & 102 & 1.52 & 2.16 & 1.76 & 7.13 & 0.126 & 1.1 & 2.98 & 2.15 & 0.446 \\
M3 & 17 & 1.08 & 1.95 & 1.41 & 13.43 & 0.189 & 1.17 & 1.44 & 1.55 & 0.321 \\
\hline
\end{tabular}

Issiodoromys pauffiensis, Mas-de-Pauffié

\begin{tabular}{|c|c|c|c|c|c|c|c|c|c|c|}
\hline & $\mathbf{N}$ & L min & $L \max$ & L mean & $\mathbf{v}$ & Sd & w min & w max & w mean & Sd \\
\hline dp4 & 28 & 2.68 & 3.26 & 2.97 & 9.76 & 0.290 & 1.05 & 1.47 & 1.26 & 0.21 \\
\hline p4 & 50 & 1.73 & 2.1 & 1.91 & 7.41 & 0.142 & 0.98 & 1.77 & 1.42 & 0.213 \\
\hline $\mathrm{m} 1-2$ & 177 & 1.51 & 2.48 & 2 & 24.25 & 0.485 & 0.93 & 2.3 & 1.62 & 0.685 \\
\hline m3 & 51 & 1.45 & 2.44 & 1.95 & 25.38 & 0.495 & 1 & 1.89 & 1.45 & 0.445 \\
\hline DP4 & 43 & 2.14 & 2.67 & 2.40 & 11.04 & 0.265 & 0.97 & 1.6 & 1.29 & 0.315 \\
\hline P4 & 57 & 1.56 & 2.04 & 1.8 & 13.33 & 0.24 & 0.98 & 2.5 & 1.48 & 0.31 \\
\hline M1-2 & 185 & 1.4 & 2.05 & 1.73 & 18.79 & 0.325 & 1 & 2.95 & 2.28 & 0.090 \\
\hline M3 & 28 & 1.14 & 1.78 & 1.46 & 21.92 & 0.32 & 1.09 & 2.07 & 1.58 & 0.49 \\
\hline \multicolumn{5}{|c|}{ Issiodoromys pauffiensis, St-Privat-des-Vieux } & $\mathbf{N}$ & $\mathrm{H}$ min. & $\mathrm{H}$ max & H mean & Sd & antcd \\
\hline \multirow{2}{*}{\multicolumn{5}{|c|}{$\begin{array}{l}\mathrm{m} 1-2 \\
\mathrm{M} 1-2\end{array}$}} & 96 & 0.77 & 3.32 & 2.51 & 0.508 & \multirow[t]{2}{*}{32} \\
\hline & & & & & 102 & 0.95 & 3.76 & 3.05 & 0.636 & \\
\hline \multicolumn{5}{|c|}{ Issiodoromys pauffiensis, Mas de Pauffié } & $\mathbf{N}$ & $\mathrm{H}$ min. & H max & H mean & Sd & antcd \\
\hline \multirow{2}{*}{\multicolumn{5}{|c|}{$\begin{array}{l}\mathrm{m} 1-2 \\
\mathrm{M} 1-2\end{array}$}} & 124 & 0.97 & 3.72 & 2.35 & 1.375 & \multirow[t]{2}{*}{79} \\
\hline & & & & & 124 & 1.14 & 4.05 & 2.6 & 1.455 & \\
\hline
\end{tabular}

Issiodoromys quercyi, Ehrenstein 7

\begin{tabular}{ccccccccc}
\hline & $\mathbf{N}$ & L min. & Lmax & Lmean & $\mathbf{v}$ & H min. & H max & Sd \\
\hline $\mathrm{m} 1-2$ & 127 & 2 & 3.13 & 2.57 & 21.16 & 0.97 & 4.81 & 0.565 \\
\hline
\end{tabular}

protoconid to the antero-lingual side of synclinid III (SIII). Labially, this cingulid shows two constant inflections: the antesinusid ahead of the protoconid, and a generally shallow pre-antesinusid. The lingual portion of the cingulid is vertically flat, and starts in continuity with the anterior cuspid of prelobe. This cuspid is prominent on unworn teeth. The size and morphology of these dp4 are very similar to that of dp4 type population (Table 2).

p4 (Fig. 5 A-C). There is a low morphological variability. A short mesio-distal expansion starting from the anterolophid inward SII is rarely observed (4/20). A small cingulid may be present at the base of the lingual opening of SIII (5/20). A p4 (1/20) bears only a remnant of the anteroconid.

m1-2. The vestigial anteroconid / antesinusid - as a mesiolabial vertical bulge - seems more frequent on molars than on $\mathrm{p} 4$, but this may be due to the more important number of m1-2. On little worn $\mathrm{m} 1-2,18 / 77$ teeth have this vestige, while it is absent (or lost due to abrasion) on 23 worn teeth. Fourteen teeth exhibit a short mesiodistal spur in SII. On a single specimen, a mesiodistal spur is added to that in the SIV. Another specimen shows a lingual interruption of the mesolophid, and displays two small lin- 


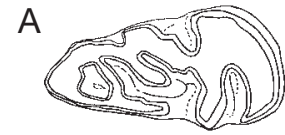

E

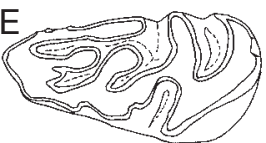

I

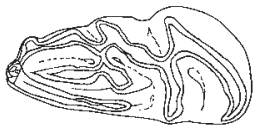

B

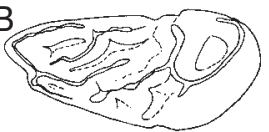

F

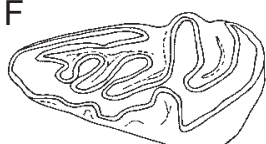

$J$

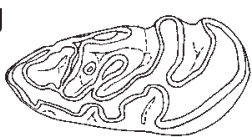

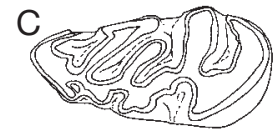

G

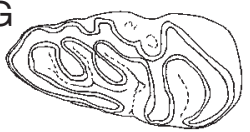

$\mathrm{K}$

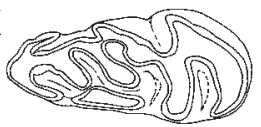

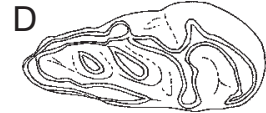

$\mathrm{H}$

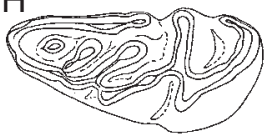

$\mathrm{L}$

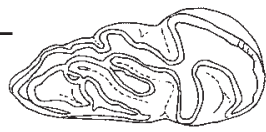

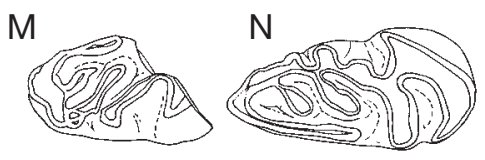
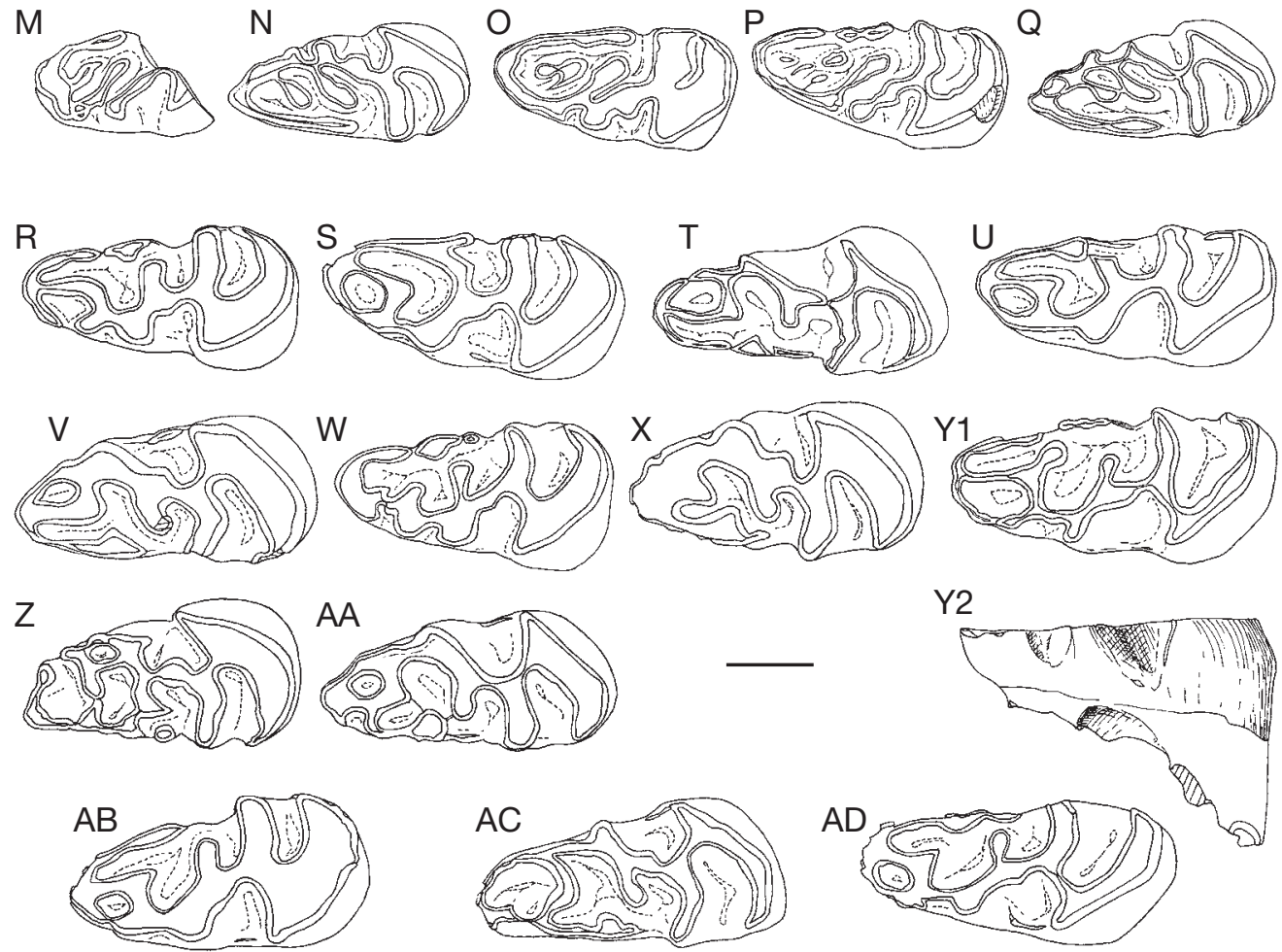

FIG. 4. - Variations of the occlusal surface of lower dp4 of Issiodoromys Bravard in Gervais, 1848: A-Q, I. pauffiensis Vianey-Liaud, 1976, from Saint-Privat-des-Vieux (Gard; Lower Chattian, MP 26): A, SPV415; B, SPV423; C, SPV433; D, SPV424; E, SPV417; F, SPV430; G, SPV425; H, SPV418; I, SPV426; J, SPV419; K, SPV437; L, SPV420; M, SPV439; N, SPV438; O, SPV429; P, SPV427; Q, SPV422; R-AF, I. quercyi (Schlosser, 1884) from Ehrenstein 7 (Germany; MP 27): R-X, Z-AD, occlusal views: R, no. 1983-XVIII 470; S, no. 1983-XVIII 457; T, no. 1983-XVIII 466; U, no. 1983-XVIII 460; V, no. 1983-XVIII 459; W, no. 1983-XVIII 458; X, no. 1983-XVIII 462; Y, no. 1983-XVIII 465, Y1, occlusal view, Y2, labial view; Z, no. 1983-XVIII 468; AA, no. 1983-XVIII 463; AB, no. 1983-XVIII 464; AC, no. 1983-XVIII 461; AD, no. 1983-XVIII 467. Scale bar: $1 \mathrm{~mm}$.

gual protrusions, the most distal one blocking the lingual opening of the SIII (Fig. 5E). The only very worn tooth $(\mathrm{H}=0.77 \mathrm{~mm})$ exhibits a thin layer of cement at the bottom of the sinusid (Fig. 5I); this cement is not visible on the other teeth. 

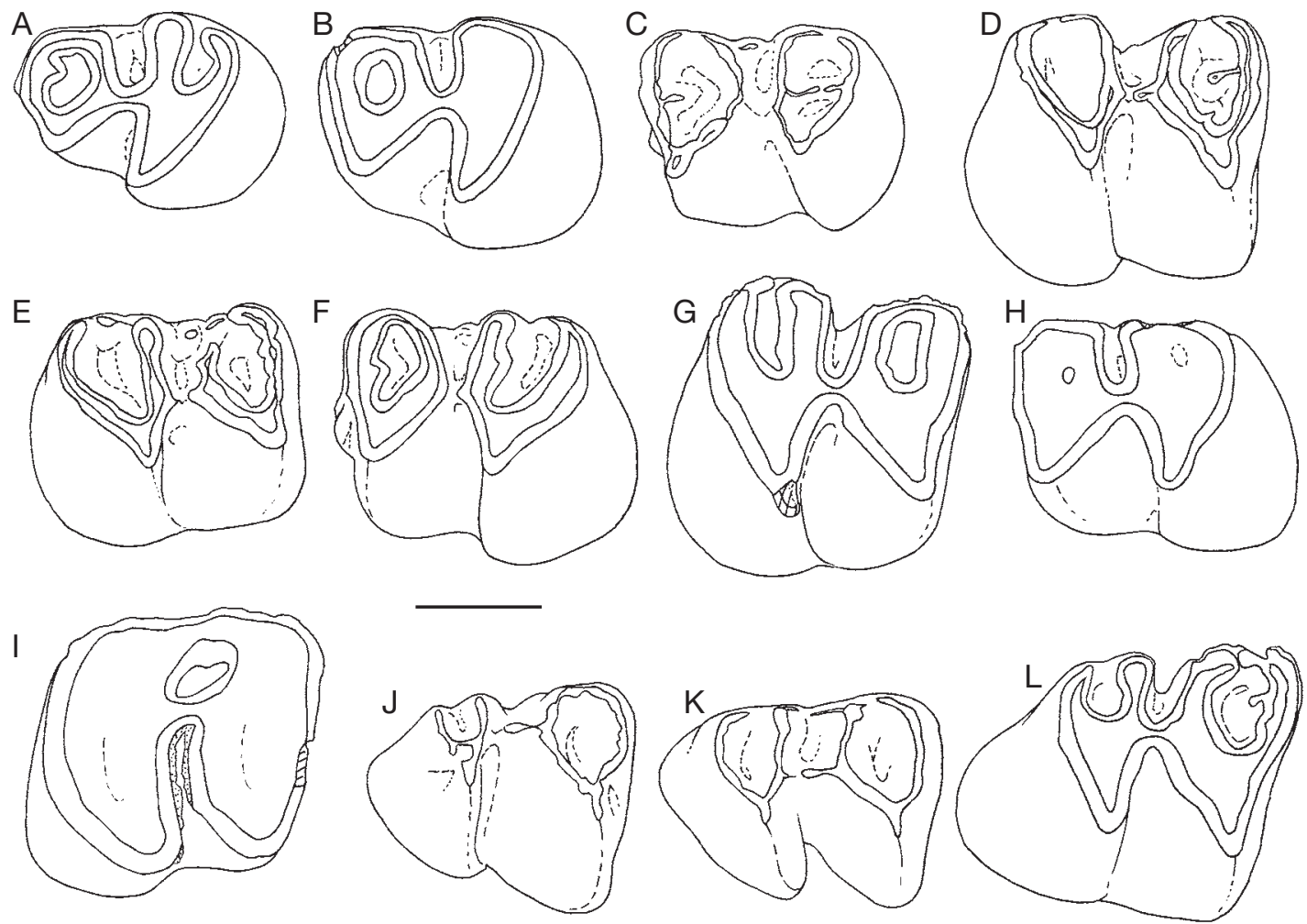

FIG. 5. - Occlusal views of lower teeth of Issiodoromys pauffiensis Vianey-Liaud, 1976 from Saint-Privat-des-Vieux (Gard; Lower Chattian, MP 26): A, left p4, SPV461; B, left p4, SPV460; C, left m1, SPV475; D, right m2, SPV481; E, right m1-2, SPV486; F, left m12, SPV507; G, right m1-2, SPV519; H, left m1-2, SPV539; I, much worn right m1-2, SPV563; J, unworn right m3, SPV574; K, unworn right m3, SPV565; L, moderately worn right $\mathrm{m3}$, SPV577. Scale bar: $1 \mathrm{~mm}$.

m3 (Fig. 5J-L). The mesiodistal spur (Fig. 5L) is present in the SII of $5 / 14$ teeth and the anteroconid is detectable on one tooth only.

\section{Upper teeth}

DP4 (Fig. 6). Again morphological variations are minimal (Fig. 6A-O). The anticline 4 may be continuous $(21 / 24)$ or split into two parts $(3 / 24)$. We observe a light variability in the labial cingulum blocking the opening of the median syncline (SII) (e.g., Fig. 6C). It is sometimes absent and sometimes high, resulting of proximity of two spurs coming from the labial ends of the anticlines 2 and 3 , or only one labial spur from the anticline 2, mesiodistal or oblique. The buccal cingular edge of the syncline III is usually swollen as a cusp that can spawn a spur extending into the syncline.
P4 (Fig. 7A-C). The lingual end of the anticline 4 is free $(12 / 29)$ or connected to the posterior cingulum (17/29). The labial portion of the anterior cingulum is rarely complete $(1 / 29)$, it is either vestigial $(11 / 29)$ or absent. The paracone is sometimes isolated from the protocone (7/29) due to the interruption of the protoloph (anticline 2).

M1-2 (Fig. 7D-K). the morphological variations are minor and mainly concern SIV, which is mostly closed (98/101), or rarely mesially opened (2/101). A small mesiodistal spur runs backwards from the anticline 3 in the SIII (1/101).

M3 (Fig. 7L, M). The size and shape of the M3 are more variable than those of M1-2, especially 

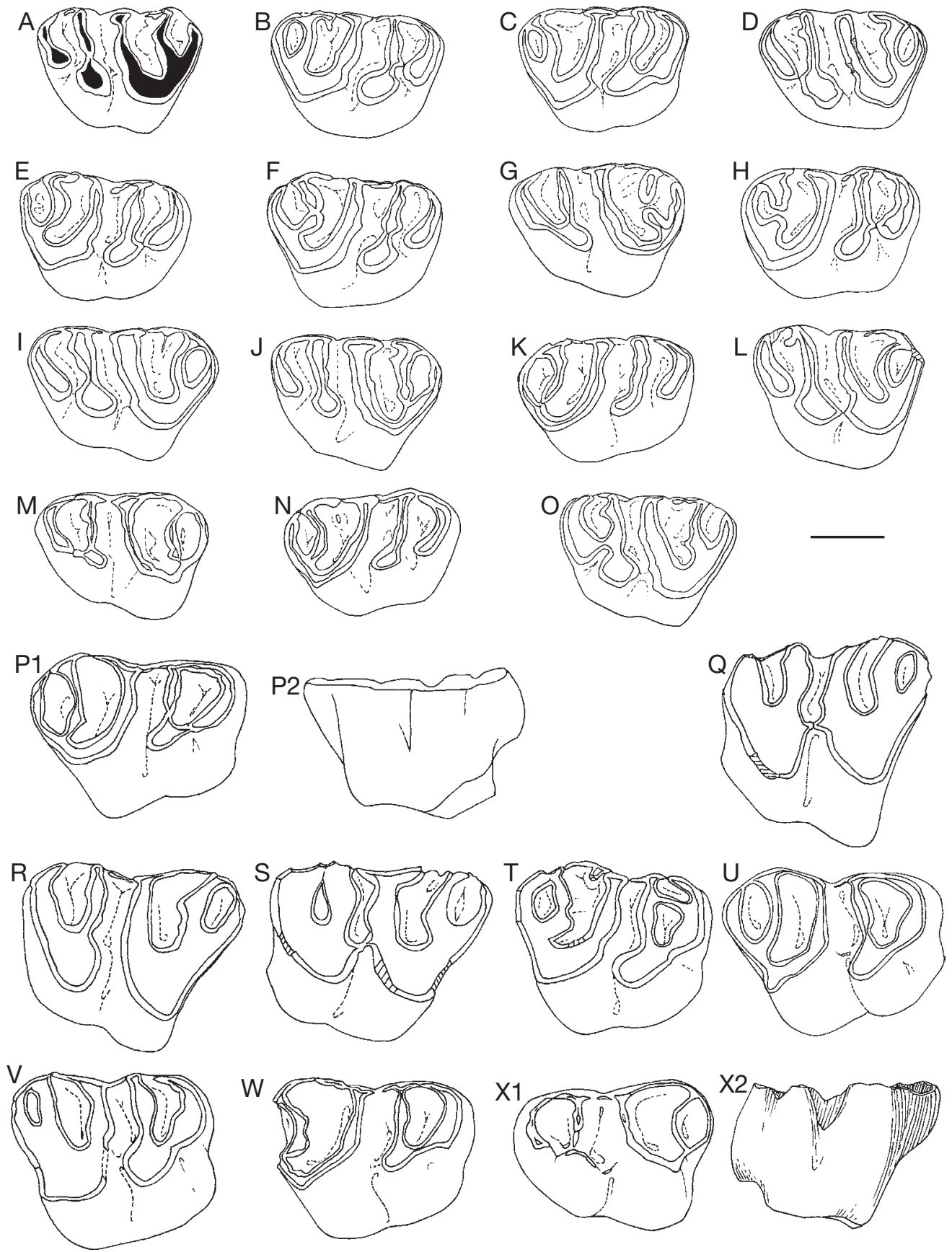

FIG. 6. - Variations of the occlusal surface of Upper DP4 of Issiodoromys Bravard in Gervais, 1848: A-O, I. pauffiensis Vianey-Liaud, 1976 from Saint-Privat-des-Vieux (Gard; Lower Chattian, MP 26): A, SPV200; B, SPV209; C, SPV219; D, SPV206; E, SPV201; F, SPV204; G, SPV205; H, SPV216; I, SPV208; J, SPV210; K, SPV213; L, SPV211; M, SPV202; N, SPV212; O, SPV222; P-X2, I. quercyi from Ehrenstein7 (Germany; MP 27): P, no. 1983-XVIII 471, P1, occlusal view, P2, lingual view; Q-W, occlusal views: Q, no. 1983-XVIII 479; R, no. 1983-XVIII 472; S, no. 1983-XVIII 473; T, no. 1983-XVIII 474; U, no. 1983-XVIII 475; V, no. 1983-XVIII 476; W, no. 1983-XVIII 477; X, no. 1983-XVIII 478: X1, occlusal view, X2, lingual view. Scale bar: $1 \mathrm{~mm}$. 

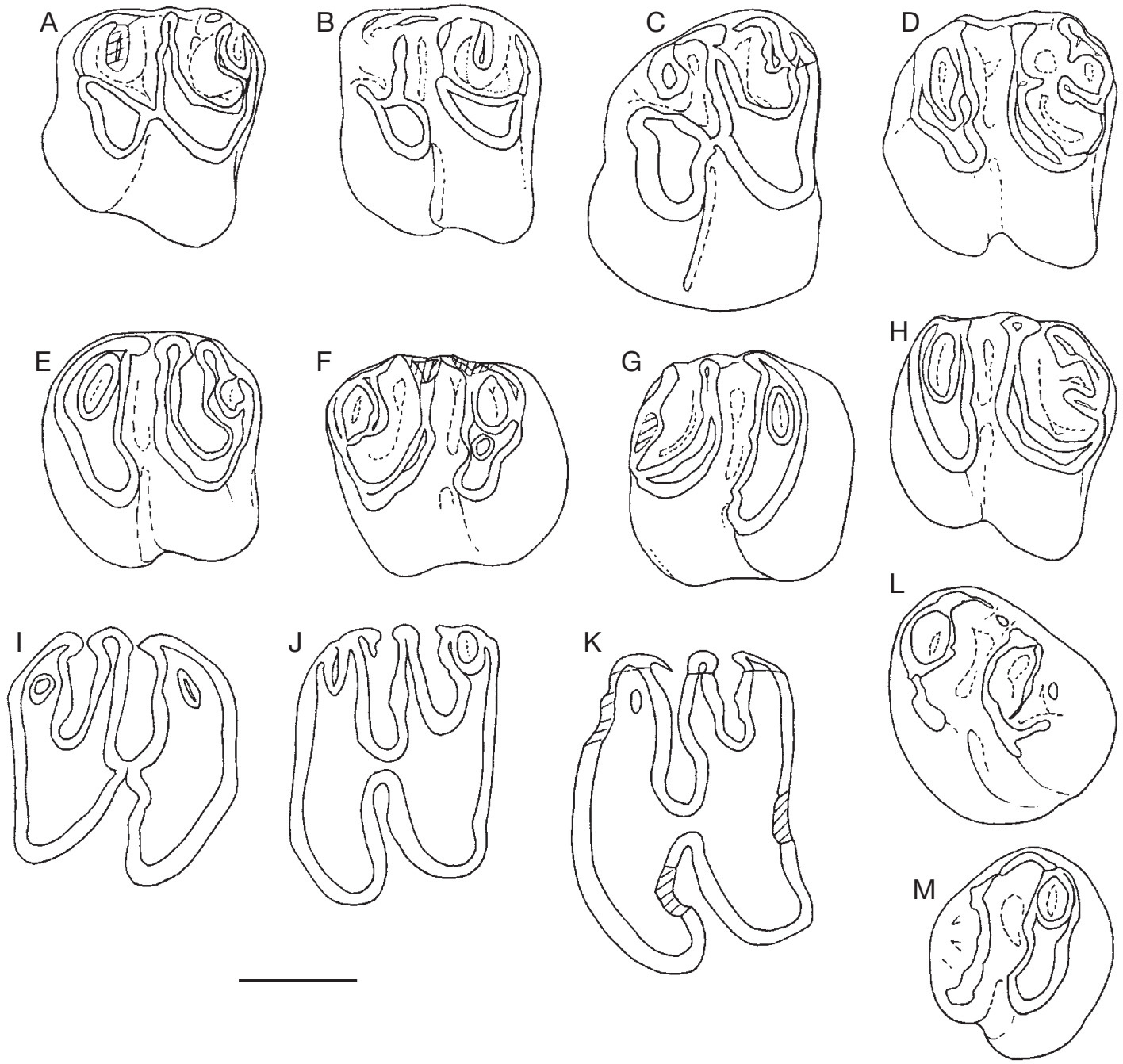

FIG. 7. - Occlusal views of upper teeth of Issiodoromys pauffiensis Vianey-Liaud, 1976 from Saint-Privat-des-Vieux (Gard; Lower Chattian, MP 26): A, left P4, SPV236; B, left P4, SPV235; C, left P4, SPV234; D, left M1-2, SPV302; E, left M1-2,SPV270; F, right M12, SPV276; G, right M1-2, SPV269; H, left M1-2, SPV278; I, worn right M1-2, SPV362; J, worn left M1-2, SPV366; K, much worn left M1-2, SPV387; L, unworn left M3, SPV390; M, moderately worn right M3, SPV396. Scale bar: 1 mm.

because of the greater or lesser reduction in the posterior lobe. On one of the smaller specimens, it only remains the anticline 3 at the back of the tooth.

\section{DisCUSSION}

Since the description of I. pauffiensis (Vianey-Liaud 1976), we collected additional material for its type locality; for the present work, it has been measured, observed and compared to that of Saint-Privat-des-Vieux. Molars from SaintPrivat-des-Vieux are similar in size to those of I. pauffiensis from Mas-de-Pauffié. Their size is significantly smaller than that of I. quercyi (Ehrenstein 7, Germany [Fig. 6P-Z; Fig. 8B], and Sarèle, France; MP 27) (Table 2).

The size variability (length and width of teeth) of I. pauffiensis from Saint-Privat-des-Vieux is not 
higher than that observed in extant populations of brachyodont rodents or other mammals (e.g., Vianey-Liaud \& Legendre 1986: 921, table 1). This variability is also less than that observed in fossil rodent teeth populations displaying a strong asymmetric hypsodonty, from both fissure fillings and stratified sedimentary deposits (e.g Vianey-Liaud \& Legendre 1986: 921, table 3). It is thus a little lower than that of the I. pauffiensis type population from Mas-de-Pauffié, or that of I. quercyi from Ehrenstein 7 (Table 2; Fig. 8B). The range of crown height is within that of species exhibiting similar to close hypsodonty (the maximum and minimum heights being slightly lower than those from Mas-de-Pauffié, and slightly higher than in I. minor from Le Garouillas). This range is clearly wider for $I$. quercyi from Ehrenstein 7, and also for I. limognensis from Pech Desse, both species being significantly more hypsodont (Fig. 8A).

Morphological variability observed in Mas-dePauffié, especially for deciduous teeth, is the same as described above for Saint-Privat-des-Vieux. Minor differences can be noted with regard to the dp4. Morphological variation in $25 \mathrm{dp} 4$ from Mas-de-Pauffié shows the same characteristics as in the population of Saint-Privat-des-Vieux, except the presence of a low cingulid which partially or completely closes the bottom of the opening of the SIII on five specimens. This cingulid is also occasionally present on $\mathrm{p} 4$ from both localities or on molars: its absence on these five dp4 may be a statistical bias.

Postcranial elements of $I$. pauffensis from Saint-Privat-des-Vieux - in particular astragali, calcanei and humeri fragments - are quite similar to those of Mas-de-Pauffié (Vianey-Liaud et al. in press).

\section{Subfamily THERIDOMYINAE \\ (Miller \& Gidley, 1918)}

Genus Protechimys Schlosser, 1884

TYPE SPECIES. - Protechimys major Schlosser, 1884 by subsequent designation of Schlosser (1884).

\section{Protechimys major Schlosser, 1884}

(Fig. 9)

HolOTYPE. - Left maxillary bearing DP4 to M2 (1879 XV 518, BSPG, Munich); Vianey-Liaud 1976.

TyPE LOCALITY. - Quercy, Old Collections.

EMENDED DIAGNOSIS. — (after Vianey-Liaud 1976: 55; 1998; Mödden 1993; Mödden \& Vianey-Liaud 1997). Evolutionary stage more progressive than in Protechimys blainvillei (Gervais, 1848) (Archaeomys gervaisi Thaler, 1966 is a junior synonym of $P$. blainvillei). Presence of a thin layer of cement even on deciduous teeth.

Lower teeth: Fusion between synclinid I and presynclinid on dp4.

Upper teeth: On P4-M3, syncline I present only in very slightly worn teeth, or missing. Syncline II absent.

Material eXamined. - Two p4 (one left p4 partly digested, one very damaged) ; one fragment of left dp4 prelobe; four complete m1-2 (three left, one right); three fragments of m1-2 trigonids, slightly worn; one right m3 heavily worn; two fragments of right maxillaries, strongly damaged (digested) bearing M1-M2, one being a very old individual; one right $\mathrm{P}$; ; one lingual fragment of left P4 heavily worn; one left M2 barely worn; one left M1-2 very old.

Measurements (in mm). - The teeth being most often damaged - including at the lower half of the crown - the measurements given here are those of length and width $(\mathrm{L} \times \mathrm{w})$ taken on the occlusal surface (see Vianey-Liaud 1979).

SPV01: left p4 moderately worn: $3.30 \times 1.71$; SVP04: right m1-2 worn: $2.56 \times 2.49$; SVP05: left m1-2 strongly worn: $2.14 \times 2.34$; SVP06: left m1-2 very little worn out: $1.91 \times 1.85$; SVP07: m1-2 moderately worn: $1.96 \times 2.71$; SVP09: right m3 heavily worn: $2.40 \times 2.24$; SPV012: left P4 moderately worn: $2.39 \times 2.51$; spv014: left M2 very little worn out: $1.66 \times 1.75$.

\section{DESCRIPTION}

The slightly worn lower teeth show the lingual opening of SII, and the marked angle of the two anticlinids bordering SII (Fig. 9A, B, D), as in P. major and P. blainvillei.

A fresh upper molar (M1-2, Fig. 9J) shows the presence of a tiny SI, and the absence of SII. The sinus occupies the entire width of the tooth, and it is oblique, like following syncline III. The syncline IV is present and open distally, but very shallow, and must disappear quickly with wear. The base of the crown is broken, which does not allow measuring 


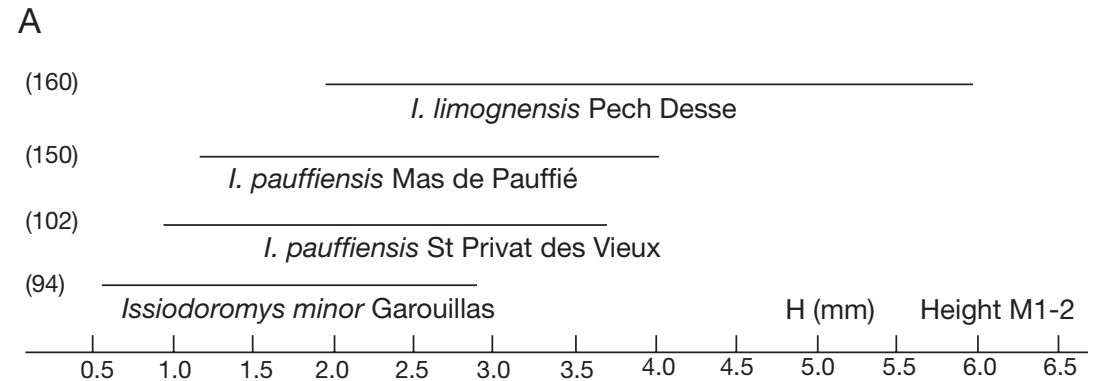

(169)

I. pauffiensis St Privat des Vieux

(94) Issiodoromys minor Garouillas $\quad \mathrm{H}(\mathrm{mm}) \quad$ Height M1-2

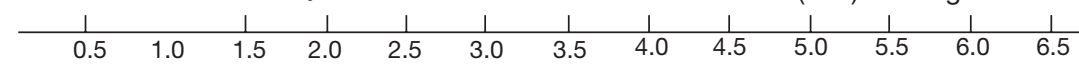

B

$$
\text { I. pauffiensis Mas de Pauffié }
$$

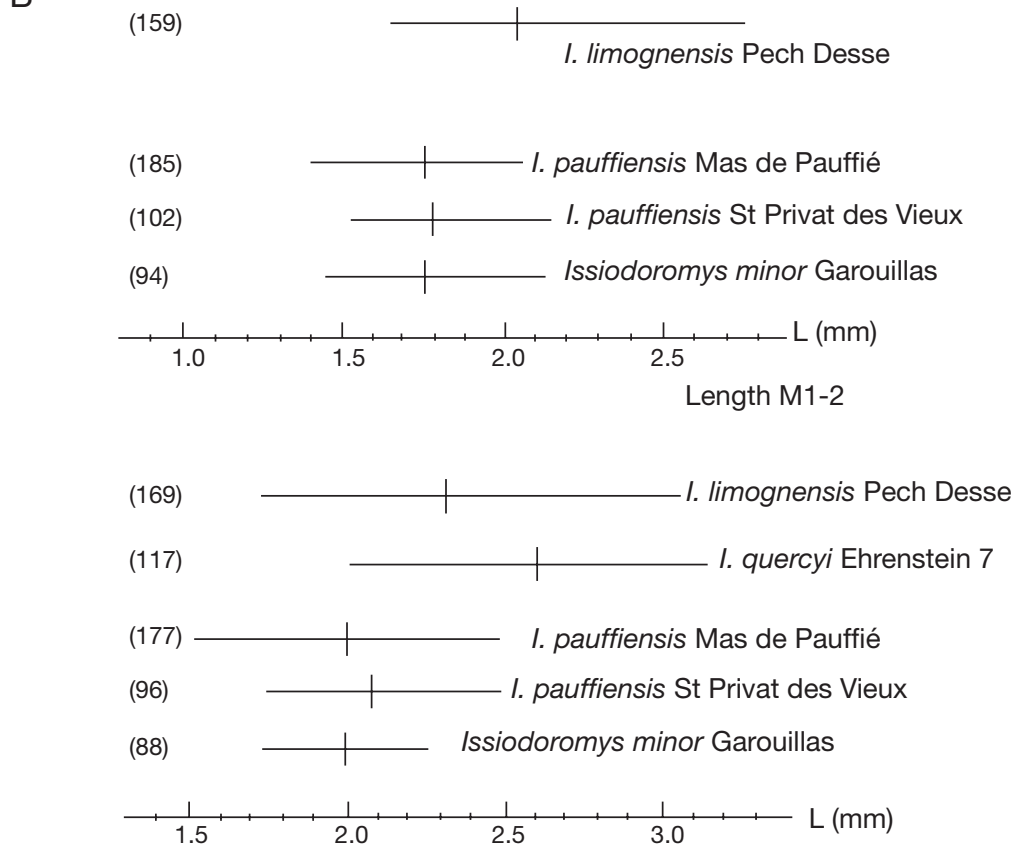

FIG. 8. - A, Height variation of the upper (M1-2) and lower (m1-2) molars of different species of Issiodoromys Bravard in Gervais, 1848; B, idem for their length. The numbers of measured teeth are indicated between brackets; mean is calculated for length only, and drawn as a short vertical line on the horizontal line representing the length variation within a sample. 
the total height. The moderately worn P4 exhibits SI and SII, SIII is absent. SIV has disappeared due to wear. In the bottom of the sinus of a much abraded M1-2, some cement is noticeable.

\section{DISCUSSION}

When compared directly with M1 or M2 of P. blainvillei of Rigal - Jouet1 and Le Garouillas (Quercy, France; MP 25), the M2 is larger and higher crowned. However, it is very similar to $P$. major from Mas-de-Pauffié and also to a new material from Les-Milles (Bouches-duRhône, France), which is also allocated to $P$. major.

\section{Family CRICETIDAE Fischer, 1817}

Genus Pseudocricetodon Thaler, 1969

Allocricetodon Freudenthal, 1994: 12-15. — de Bruijn et al. 2003: 61, 62.

TYPE SPECIES. - Pseudocricetodon montalbanensis Thaler, 1969 by monotypy.

Diagnosis. - (Combining the original diagnosis of Thaler 1969; Vianey-Liaud 1974; Dienemann 1987; de Bruijn et al. 2003; Kalthoff 2006): small to medium-sized cricetid; infra-orbitary foramen hystricomorph, a little pinched dorsally; flat palate (Vianey-Liaud 1974); lower incisors with highly derived enamel (type 7-8, Kalthoff 2006); lophodont molar pattern; main cusps and crests slender and usually straight, rarely irregular, separated by valleys with a flat bottom; wide anterocone on M1 and lingual border of M1 straight or slightly concave.

\section{REMARK}

The most abundant (144 teeth) Cricetidae of SaintPrivat-des-Vieux is assigned to Pseudocricetodon incertus (Schlosser, 1884). The cricetid material from BoujacA, in the same sedimentary basin, had also been allocated to this species (Comte 1985). In his description of the material from the province of Teruel (Spain), Freudenthal (1994) had erected the genus Allocricetodon for medium-sized forms of the genus Pseudocricetodon Thaler, 1969. The validity of this new genus is discussed by de Bruijn et al. (2003). In agreement with their conclusions, we consider here the genus Allocricetodon as synonymous to the genus Pseudocricetodon. Two taxa described by Freudenthal (1994) from the Oligo- cene of Mirambueno (Spain) can be identified in the Alès Basin: Pseudocricetodon (non Allocricetodon) incertus and Pseudocricetodon (non Allocricetodon) landroveri Freudenthal, 1994. We compare the abundant population from Saint-Privat-des-Vieux (MP 26) with that of MIR4C, from Mirambueno (MP 26). We expand the comparison to the cricetids of younger localities: on the one hand, BoujacA (MP 27) in the Alès basin where P. incertus is also recorded and, on the other hand, MIR1 at Mirambueno (Teruel, Spain; MP 27) from which another species - Pseudocricetodon cornelii (Freudenthal, 1994) - has been described (Freudenthal 1994).

\section{Pseudocricetodon incertus (Schlosser, 1884)}

(Fig. 10)

Cricetodon incertum Schlosser, 1884: pl. VIII, fig. 19a. - Schaub 1925: 45-49, pl. II, fig. 1 .

Pseudocricetodon incertus - Hugueney 1980: 60, figs 7-9.

Allocricetodon incertus - Freudenthal 1994: 18, pl. 4, figs 7-12.

DiAGNOSIS. - Comte 1985: 42, 43.

Holotype. - Left dentary, bearing m2-m3, no. 1879. XV.171a (coll. BSPG, Munich), Schlosser 1884.

TyPe LOCALITY. - Mouillac (Quercy, Old Collections).

Distribution. - Late Oligocene: MP 26 to MP 29 (cf. e.g., Comte 1985)

Material And MEasurements (Tables 3, 4). - The normality of distributions was tested by the coefficient of variation of Pearson (100 Sd / average) distributed normally between four and ten for mammals (e.g., Simpson et al. 1960). In cases where this ratio was less than four, the normality of the samples was checked by the Shapiro-Wilk test (L.M3 / W $=0.855>\mathrm{W} 0.05$; w M / 1: $\mathrm{W}=0.9543>\mathrm{W} 0.05, \mathrm{LM} / 2: \mathrm{W}=0.9488>\mathrm{W} 0.05)$.

\section{DESCRIPTION}

\section{Upper molars}

M1. The prelobe is always larger than half the tooth width, and on most of the teeth $(33 / 37)$ there is a sharp angle between its lingual side and the mesial flank of the protocone. This angle is less defined on four specimens. 

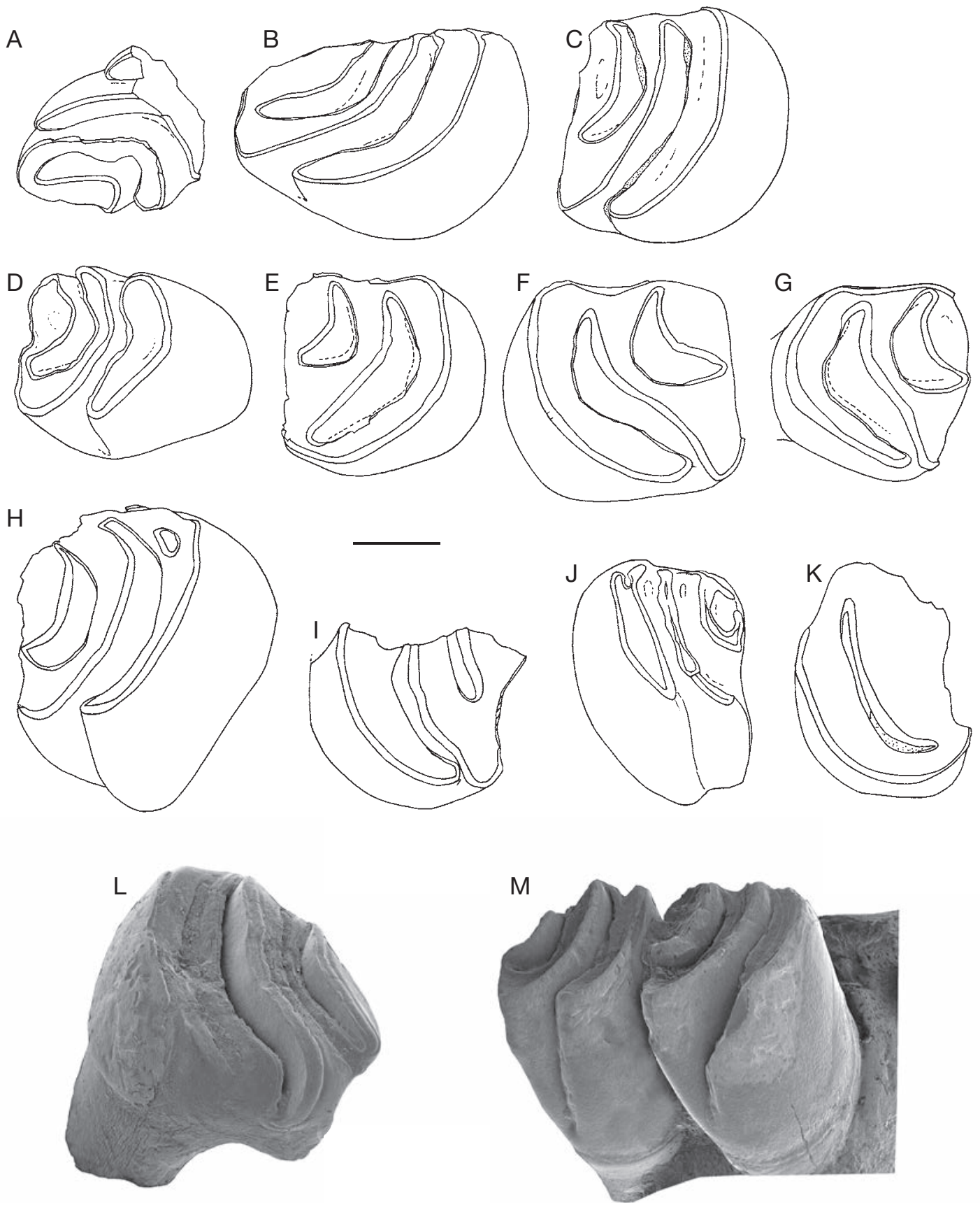

FIG. 9. - Occlusal views of teeth of Protechimys major Schlosser, 1884, from Saint-Privat-des-Vieux (Gard; Lower Chattian, MP 26): A, fragment of right dp4, SPV03; B, left p4, SPV01; C, left m1-2, SPV05; D, left ?m1-2, SPV04; E, worn left m1-2,SPV06; F, worn right m1-2, SPV07; G, left P4, SPV12; H, fragment of right P4, SPV13; I, weakly worn left M1-2, SPV14; J, strongly worn left M1-2, SPV15; K, much worn left M1-2, SPV; L, a little digested right p4, SPV03; M, moderately worn and digested right M1-M2, SPV10. Scale bar: $1 \mathrm{~mm}$. 
TABLE 3. - Measurements of Pseudocricetodon incertus (Schlosser, 1884) from Saint-Privat-des-Vieux. Abbreviations: Sd, standard deviation; Sd2, variance; v, Pearson's coefficient.

\begin{tabular}{lrllcccc}
\hline \multicolumn{7}{l}{ Pseudocricetodon incertus, Saint-Privat-des-Vieux } \\
\hline Length & $\mathbf{n}$ & min. & max. & mean $\pm \mathbf{1 0 0 s d} / \mathbf{m e a n}$ & $\mathbf{s d}$ & $\mathbf{s d 2}$ & $\mathbf{v}$ \\
\hline M1 & 36 & 1.74 & 2.11 & $1.91 \pm 0.015$ & 0.08952 & 0.00801 & 4.69 \\
M2 & 29 & 1.29 & 1.54 & $1.41 \pm 0.012$ & 0.06316 & 0.00399 & 4.46 \\
M3 & 8 & 1.17 & 1.27 & $1.21 \pm 0.014$ & 0.04015 & 0.00161 & 3.32 \\
m1 & 17 & 1.47 & 1.75 & $1.62 \pm 0.017$ & 0.07194 & 0.00517 & 4.44 \\
m2 & 32 & 1.42 & 1.61 & $1.52 \pm 0.010$ & 0.05644 & 0.00319 & 3.70 \\
m3 & 11 & 1.30 & 1.45 & $1.39 \pm 0.017$ & 0.05605 & 0.00314 & 4.03 \\
\hline Width & $\mathbf{n}$ & min. & max. & moy $\pm \mathbf{1 0 0}$ sd/mean & sd & sd2 & $\mathbf{v}$ \\
\hline M1 & 36 & 1.11 & 1.42 & $1.24 \pm 0.013$ & 0.07861 & 0.00618 & 6.31 \\
M2 & 28 & 1.22 & 1.44 & $1.35 \pm 0.010$ & 0.05459 & 0.00298 & 3.99 \\
M3 & 8 & 1.18 & 1.45 & $1,27 \pm 0.039$ & 0.11263 & 0.01268 & 8.86 \\
m1 & 17 & 1.04 & 1.16 & $1.09 \pm 0.008$ & 0.03321 & 0.00110 & 3.04 \\
m2 & 32 & 1.14 & 1.34 & $1.24 \pm 0.010$ & 0.05827 & 0.00339 & 4.70 \\
m3 & 10 & 1.09 & 1.27 & $1.16 \pm 0.018$ & 0.05896 & 0.00347 & 5.08 \\
\hline
\end{tabular}

On most teeth, the anterocone is simple and more or less transversely stretched (32/37). A tendency to split occurs (5/37). A spur behind the anterocone is present on 13 of the 35 teeth: it ends (10/13) in the prelobe basin. It bends to reach the lingual cingulum (2/13); on a single specimen (SPV 30) it connects to the anterior arm of the protocone. On most of the other teeth (33/35), this arm, which can be bent to the paracone, ends freely in the anterosinus. A crest is frequently observed in front of the paracone (18/35): it can be short $(2 / 15)$ or bend to reach the labial cingulum (1/15), but in most cases $(15 / 18)$ it joins the anterocone (= anterior ectoloph, according to the nomenclature of Freudenthal et al. 1994: 61). The lingual anteroloph joins the front side of the protocone in 31 teeth out of 35 , closing the protosinus. More often interrupted (12/35), the labial anteroloph closes the anterosinus in 23 of 35 teeth.

The platform of the protocone ("triangle lingually to the anteroloph and in front of the protocone"; Freudenthal 1994: 9) is observed over about half of M1 (15/35); it is well established on the $2 / 3$ of them (10/35). The protolophule is widely retroverted i.e. connected to the back of the protocone or to the endoloph (38/39), and in one case, it is linked to the protocone (transverse). A single tooth (SPV 54) also shows the connection of the anterior arm of the protocone with the paracone: therefore two junctions between the anterior cusps are present. The sinus is strongly proverse (it frequently ends between the protocone and the paracone: $31 / 39$ ), just proverse in other cases (8/39). The lingual cingulum is rarely complete, and in this cases (2/39), completely closing the opening of the sinus. This cingulum is absent on about half of the teeth (21/39). An entostyle, more or less developed, is visible in 10 teeth (10/39); it can be isolated (3/39) or associated with an incomplete lingual cingulum (7/39).

The mesoloph is absent on SPV 50 (1/38), medium in length on about 23/38 specimens, sometimes it is a little shorter $(6 / 38)$, and more rarely $3 / 4$ length (2/38). It connects the labial edge of $6 / 38$ specimens with an interruption on one of them. The mesostyle is absent on 4/37 teeth, in other cases (22/37) it forms a cingular crest bearing $(6 / 37)$ or not a cusp, the cusp being isolated $(11 / 37)$. An entomesoloph is visible on SPV 47 . The metalophule is always proverse (36/36). On about $2 / 3$ of the teeth (22/33), a more or less developed crest is observed on the distal flank of the paracone; occasionnally oblique to the labial edge, it can be connected to the mesostyle. A short ridge in front of the metacone is visible on two teeth (SPV 31 and SPV 39). In most cases (32/36) the posteroloph ends freely, leaving open the posterosinus; except on four teeth on which it closes the latter, curving toward the posterior wall of the metacone. 
TABLE 4. - Comparisons of measurements of different species of Pseudocricetodon Thaler, 1969: P. cornelii (Freudenthal, 1994) and P. incertus (Schlosser, 1884). Abbreviations: MIR, Mirambueno (Teruel, Spain); Sd, standard deviation; (1), Measurements according to Freudenthal 1994. Measurements in $0.1 \mathrm{~mm}$.

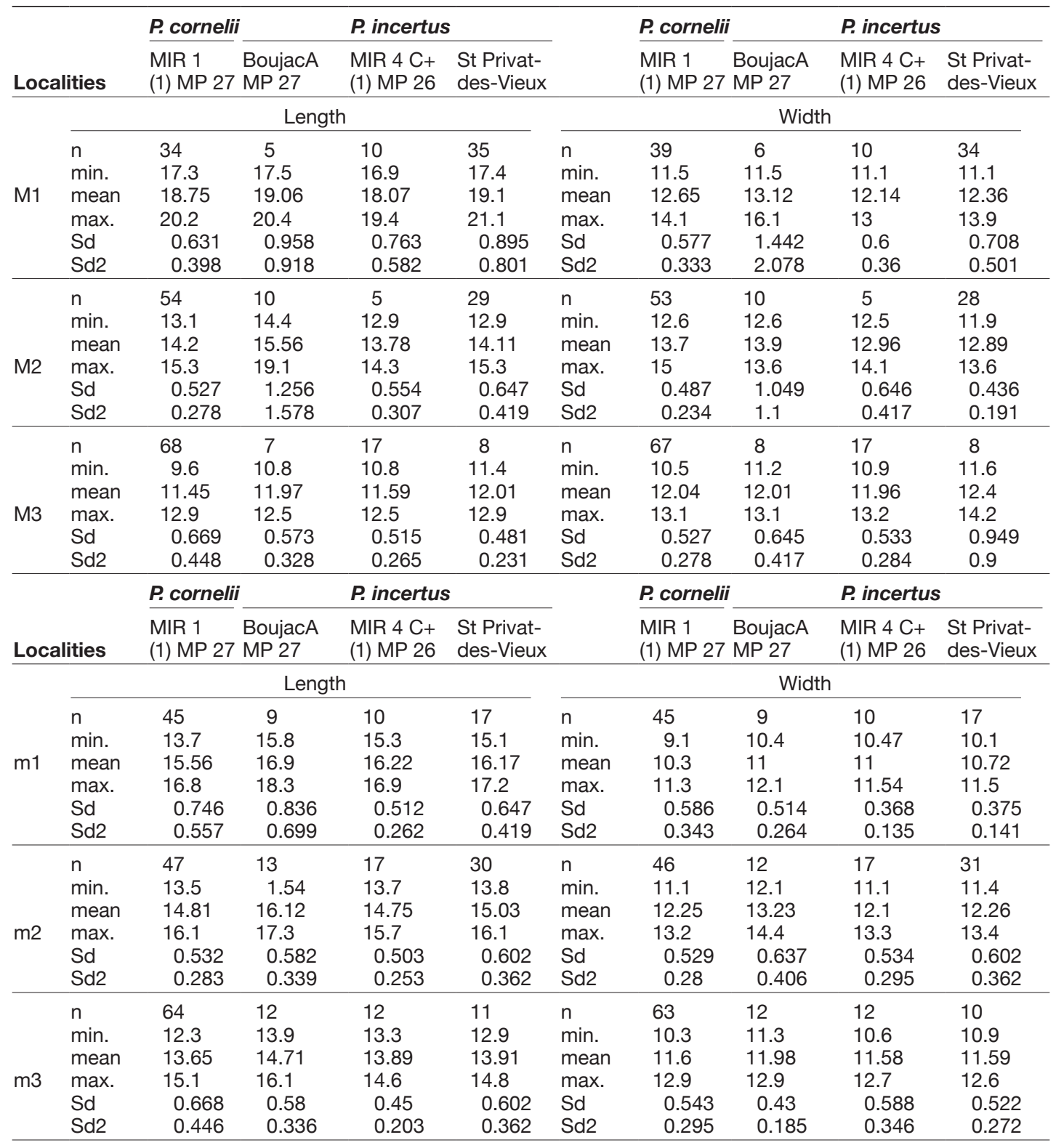

M2. The anterior lingual cingulum is most often a low ridge without individualized protosinus; on $(22 / 31)$ well developed and clearly defines a pro- the contrary, it is highly developed on five other tosinus; on four specimens (4/31), it is reduced to teeth $(5 / 31)$ where it extends over the inner side 
of the tooth, skirting the protocone. On SPV 88, there is a labial connection between the anteroloph and the protolophule. The latter is attached on the anterior arm of the protocone. Beyond its junction with the endoloph, the posterior arm of the protocone extends mostly towards the paracone without reaching it (23/31); a complete double link of the anterior cusps is performed on 6 specimens $(6 / 31)$. No trace of this double linking is visible on SPV 66 and SPV 80.

The sinus, almost transverse on SPV 75, does not extend deeply behind the protocone (24/31); it can be seen clearly around the protocone on 6 specimens. On SPV 63 there is a ridge on the posterior flank of the protocone, while on SPV 79 a complete but low protocone - hypocone connection is present.

The mesoloph is usually of medium length (18/30), long in other cases $(12 / 30)$, and it can reach the labial edge (6/30) but it is interrupted on two specimens. A link metaloph - mesoloph is seen on two teeth. A second mesoloph is present on SPV 83. A complete (6/29) or incomplete labial cingulum, is present on the majority of teeth $(28 / 29)$; on SPV 71, it is a small cusp independent of the mesoloph. On about half of the teeth $(15 / 29)$ this cingulum is in line $(9 / 15)$, either directly or after an interruption, with a more or less developed ridge descending obliquely from the top of the paracone. The metaloph, proverse $(31 / 31)$, is inserted on the anterior arm of the hypocone more or less in front of this cusp. On SPV 79, behind the metaloph, a ridge runs towards the posteroloph without reaching it. The posterior cingulum joins the metaloph, closing the posterosinus (9/30).

M3. The lingual anteroloph is present in seven of eight specimens, only weakly indicated for three of them on which the protosinus is absent. Four other teeth show a strong anteroloph defining a sharp protosinus; the anterolingual cingulum extends to the hypocone. The protolophule is connected to the anterolophule $(4 / 6)$ or anterocone. The sinus is absent (3/8), small (3/8) or deep (2/8), the neoendoloph being missing or incomplete. The mesoloph is either absent (1/8), of medium length $(2 / 8)$, or long $(2 / 8)$, reaching the labial edge on three other specimens. The endoloph is complete
$(5 / 8)$ or absent $(3 / 8)$. The axioloph is complete $(2 / 8)$, incomplete $(3 / 8)$ or absent $(3 / 8)$. A complete labial cingulum closes the mesosinus only on half the teeth (4/8). The metacone forms a swollen cusp on five specimens (5/7); it is merged in the labial ridge on the others $(2 / 7)$. In continuation of this ridge, the posteroloph closes the posterosinus on most specimens $(6 / 7)$.

\section{Lower teeth}

$\mathbf{m} 1$. The anteroconid position is axial or slightly offset lingually. The lingual anterolophid is absent on SPV 110. On the other teeth, it joins (12/17) or not $(4 / 17)$ the metaconid. The labial anterolophid is short $(5 / 15)$, or progressively runs down the base of the protoconid (10/15). The anterolophulid is complete (18/18), obliquely to the axis of the ectolophid. The metalophulid is absent $(6 / 16)$ or reduced to a short spur $(10 / 16)$. The posterior arm of the protoconid is always connected to the metaconid (18/18); the mesolophid is short (2/16), mostly halflong (11/16) or long (3/16), without reaching the lingual side. A second mesolophid is present on four teeth. The sinusid is most often slightly oriented backward, and transverse on two teeth (2/18); it is closed by a discrete and often incomplete cingulum. A poorly developed ectomesolophid is present on four specimens (4/17). The hypolophulid is attached in front of the anterior arm of the hypoconid (17/18); it is interrupted before this junction on SPV 112, and directly connected at the hypoconid on SPV 113. The posterosinus is closed by the prolongation of the posterolophid toward the entoconid. The posterior arm of the hypoconid is absent.

m2. The tooth SPV 149 has a short labial anterolophid; it descends to the base of the protoconid on all other specimens (32/33). The anterolophulid is complete (32/32) and almost as high as the anteroconid. The metalophulid is complete, obliquely forwards, and is always inserted on the anterior arm of protoconid. A crest behind the metalophid (metalophulid II?) connects to the posterior arm of the protoconid on SPV 130. It generally ends free. It is short on SPV 124 or generally of medium length (28/33); on some specimens $(4 / 33)$ it curves toward the 

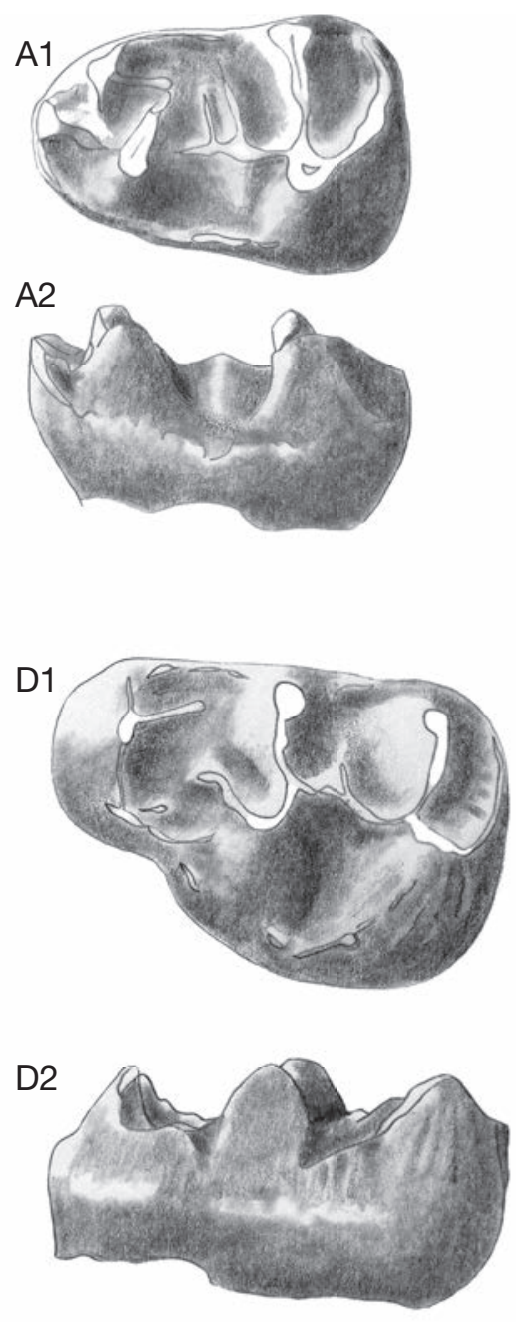
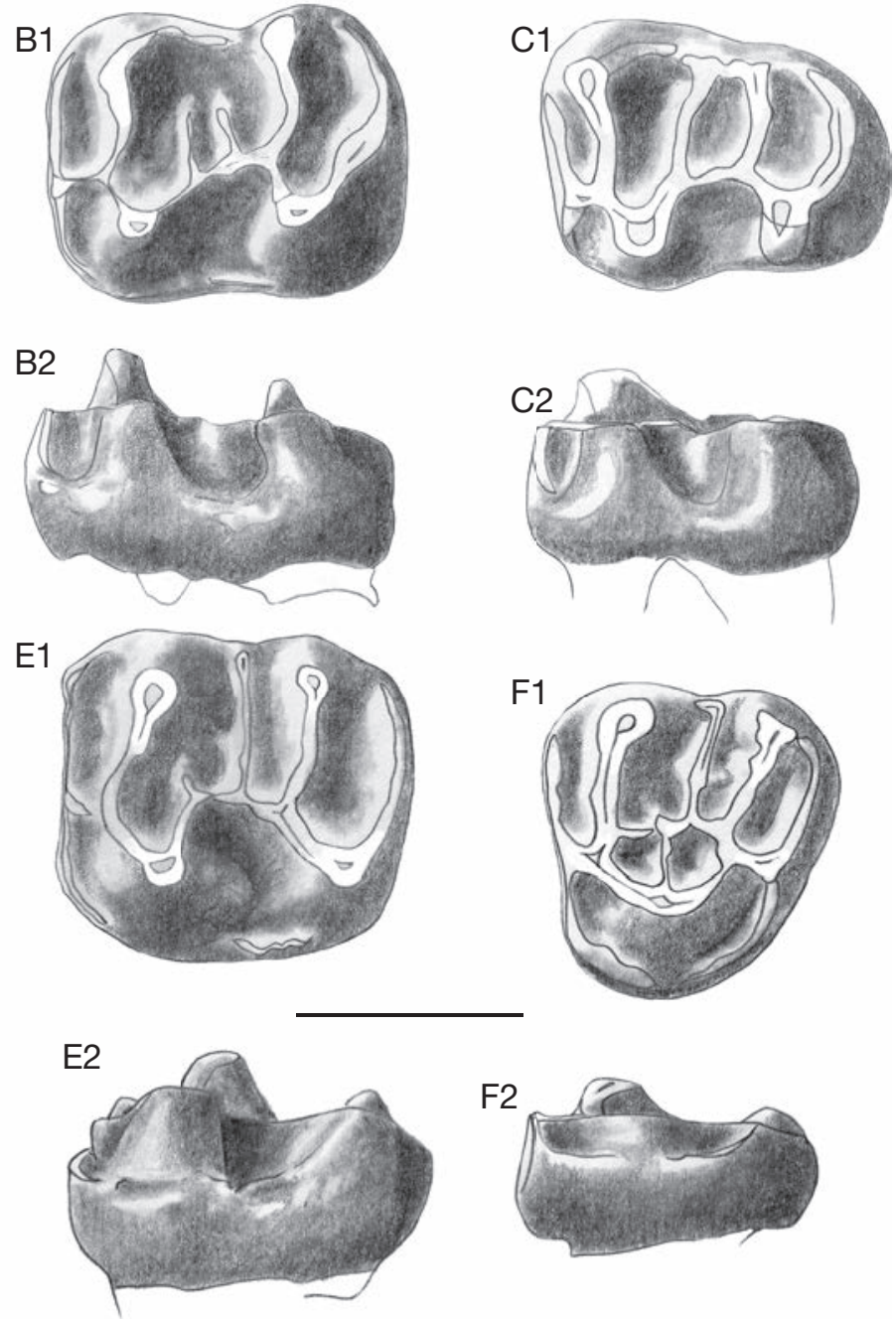

FIG. 10. - Pseudocricetodon incertus (Schlosser, 1884) from Saint-Privat-des-Vieux (Gard; Lower Chattian, MP 26): A, left m1, SPV109: A1, occlusal view, A2, lingual view; B, left m2, SPV131: B1, occlusal view, B2, lingual view; C, left m3, SPV155: C1, occlusal view, C2, lingual view; D, left M1, SPV26: D1, occlusal view, D2, lingual view; E, left M2, SPV61: E1, occlusal view, E2, lingual view; F, left M3, SPV93: F1, occlusal view, F2, lingual view. Scale bar: $1 \mathrm{~mm}$.

metaconid. The mesoconid is rarely distinct. The mesolophid may be absent (8/33), short (6/33), halflong $(16 / 33)$ or long $(3 / 33)$, and in this case, it can be very low and slender (SPV 130). About one third of the teeth (10/33) have an ectomesolophid. The sinusid, tranverse (15/33) or weakly retroverted $(18 / 33)$ is closed on most specimens $(28 / 31)$ by a low and often incomplete cingulum. On the lingual side, the distal flank of the metaconid forms a ridge down to the base of the entoconid, but without joining it. The hypolophid is generally (30/33) inserted onto the anterior arm of the hypoconid and oblique forward; it is transverse, inserted just before the hypoconid on three specimens (3/33). Lingually, the posterolophid joins the top of the entoconid, closing strongly the posterosinusid. The posterior arm of the hypoconid is absent. 
TABLE 5. - Comparisons of measurements of Pseudocricetodon incertus (Schlosser, 1884) from MP 26. Abbreviations: BJA, BoujacA; MIR 4C, Mirambueno 4C; SPV, Saint-Privat-des-Vieux; d.f, degree of freedom. Abbreviations: $\mathbf{t}$, student test; $\mathbf{n}$, number of teeth; sign., significance.

\begin{tabular}{|c|c|c|c|c|c|c|c|}
\hline \multirow[b]{2}{*}{ Length } & \multicolumn{2}{|c|}{ MIR 4C } & \multicolumn{5}{|c|}{ SPV } \\
\hline & $n$ & MP 26 & $n$ & MP 26 & $\mathrm{t}$ & d.f & Sign. \\
\hline$\overline{\mathrm{M} 1}$ & 10 & 1.81 & 36 & 1.91 & 3.15 & 44 & + \\
\hline M2 & 5 & 1.378 & 29 & 1.415 & 0.12 & 29 & - \\
\hline M3 & 17 & 1.159 & 8 & 1.21 & 2.32 & 23 & -0.04 \\
\hline $\mathrm{m} 1$ & 10 & 1.622 & 17 & 1.62 & 0.07 & 25 & - \\
\hline $\mathrm{m} 2$ & 17 & 1.475 & 32 & 1.52 & 2.7 & 47 & + \\
\hline \multirow[t]{2}{*}{$\mathrm{m} 3$} & 12 & 1.389 & 11 & 1.393 & 0.18 & 21 & - \\
\hline & \multicolumn{2}{|c|}{ MIR 4C } & \multicolumn{5}{|c|}{ SPV } \\
\hline Width & $\mathrm{n}$ & MP 26 & $\mathrm{n}$ & MP 26 & $\mathrm{t}$ & d.f & Sign. \\
\hline$\overline{\mathrm{M} 1}$ & 10 & 1.214 & 36 & 1.24 & 0.94 & 44 & - \\
\hline M2 & 5 & 1.296 & 28 & 1.35 & 1.95 & 32 & - \\
\hline M3 & 17 & 1.2 & 8 & 1.27 & 2.14 & 23 & -0.04 \\
\hline $\mathrm{m} 1$ & 10 & 1.1 & 17 & 1.09 & 0.7 & 25 & - \\
\hline $\mathrm{m} 2$ & 17 & 1.21 & 32 & 1.24 & 1.72 & 47 & - \\
\hline m3 & 12 & 1.16 & 10 & 1.16 & 0.08 & 20 & - \\
\hline
\end{tabular}

\begin{tabular}{|c|c|c|c|c|c|c|c|}
\hline \multirow[b]{2}{*}{ Length } & \multicolumn{2}{|c|}{ BJA } & \multicolumn{5}{|c|}{ SPV } \\
\hline & $n$ & MP 27 & $n$ & MP 26 & $\mathrm{t}$ & d.f & Sign. \\
\hline$\overline{M 1}$ & 4 & 1.9 & 36 & 1.91 & 0.21 & 38 & - \\
\hline M2 & 11 & 1.5 & 28 & 1.42 & 4.06 & 37 & + \\
\hline M3 & 7 & 1.19 & 8 & 1.21 & 1.05 & 13 & - \\
\hline $\mathrm{m} 1$ & 8 & 1.64 & 17 & 1.62 & 0.72 & 23 & - \\
\hline $\mathrm{m} 2$ & 10 & 1.59 & 32 & 1.52 & 3.54 & 40 & + \\
\hline \multirow[t]{2}{*}{ m3 } & 10 & 1.49 & 11 & 1.39 & 4.08 & 19 & + \\
\hline & \multicolumn{2}{|c|}{ BJA } & \multicolumn{5}{|c|}{ SPV } \\
\hline Width & $n$ & MP 27 & $\mathrm{n}$ & MP 26 & $\mathrm{t}$ & d.f & Sign. \\
\hline$\overline{\mathrm{M} 1}$ & 4 & 1.3 & 36 & 1.24 & 1.2 & 38 & - \\
\hline M2 & 11 & 1.41 & 28 & 1.35 & 3.04 & 37 & + \\
\hline M3 & 8 & 1.18 & 8 & 1.27 & 2.02 & 14 & - \\
\hline $\mathrm{m} 1$ & 8 & 1.09 & 17 & 1.09 & 0.05 & 23 & - \\
\hline $\mathrm{m} 2$ & 10 & 1.3 & 32 & 1.24 & 2.95 & 40 & + \\
\hline m3 & 10 & 1.19 & 10 & 1.16 & 1.03 & 18 & - \\
\hline
\end{tabular}

m3. The labial portion of the anterolophid always reaches the base of the protoconid (10/10), while its lingual part is connected to the metaconid. The metalophulid is complete and connected to the anterolophulid (7/10) or to the anteroconid (3/10). Behind the metalophid, two teeth (2/11) show a ridge that does not reach the posterior arm of the protoconid. The latter is long, freely ending (10/11), and joins the lingual edge only on SPV 155. The mesolophid is absent $(11 / 11)$. There is no mesoconid, and two teeth (2/11) have an ectomesolophid. On all teeth a crest, variable in thickness, runs down from the metaconid and closes the mesosinusid. The sinusid is most often closed by a cingulum more or less complete (9/10). The hypolophulid oblique forward fits the anterior arm of the hypoconid, more or less in front of this cuspid. The posterolophid is connected lingually to the top of the entoconid, strongly closing the posterosinus. The posterior arm of the hypoconid is absent.

Incisors. Numerous lower incisors display an ornamentation of longitudinal ribs associated with ribs becoming oblique labially. This pattern is similar to that of two fragments of incisors from BoujacA (Gard, Alès basin; MP 27) assigned to Pseudocricetodon incertus (Comte 1985: 34, fig. 11g, h, and 47, 48).

\section{REMARK AND COMPARISONS}

The species Pseudocricetodon incertus was reported from BoujacA (MP 27; Alès Basin, France) on the basis of a relatively small sample (Comte 1985). Freudenthal (1994: 19) notes strong contradictions in the size distributions at MIR4C and BoujacA, suggesting that the material contains more than one species in this latter locality. The comparison of BoujacA material with the more abundant one now known from Saint-Privat-des-Vieux, in the same basin, allows adopting this view. A few teeth (one M1, one M3, one $\mathrm{m} 1$ and two m2) must be separated out of BoujacA material initially assigned to P. incertus. They demonstrate the existence of a larger form that could be affine to Pseudocricetodon landroveri (Daams, Freudenthal, Lacomba \& Alvarez, 1989), a species initially considered as a small species of the genus Heterocricetodon Schaub, 1925.

Therefore, a few teeth from BoujacA belong to Pseudocricetodon aff. landroveri (Daams et al. 1989: 43-48): $\mathrm{m} 1$ (BJA763): $1.86 \times 1.23 \mathrm{~mm}, \mathrm{~m} 2$ (BJA780): $1.64 \times 1.51 \mathrm{~mm}, \mathrm{~m} 2$ (BJA781): $1.72 \times$ $1.43 \mathrm{~mm},($ BJA726): $1.81 \times 1.63 \mathrm{~mm}, \mathrm{M} 3$ (BJA750): $1.29 \times 1.31 \mathrm{~mm}$. The dimensions of these teeth fall within the range of variation of the type species from Pareja (Guadalajara, Spain; Daams et al. 1989), except for the M2 ( $\mathrm{L}=1.81 \mathrm{~mm})$ which is longer than in Pareja (L. $\max =1.71 \mathrm{~mm}$ ), and rather in 
TABLE 6. - Comparisons of characters (chi²) of Pseudocricetodon incertus (Schlosser, 1884) and P. cornelii (Freudenthal, 1994) from MP 27. Abbreviations: f, frequency; s, significance; MIR1, Mirambueno 1; MIR 4C, Mirambueno 4C; SPV, Saint-Privat-des-Vieux.

\begin{tabular}{|c|c|c|c|c|c|c|c|c|}
\hline & \multirow[b]{3}{*}{ Characters } & \multicolumn{4}{|c|}{$P$ incertus } & \multirow{2}{*}{\multicolumn{3}{|c|}{$\begin{array}{c}\text { P. cornelii } \\
\text { MIR1 }\end{array}$}} \\
\hline & & \multirow{2}{*}{$\begin{array}{c}\text { SPV } \\
f\end{array}$} & \multicolumn{3}{|c|}{ MIR4C } & & & \\
\hline & & & f & chi ${ }^{2}$ & $\mathbf{s}$ & f & chi $^{2}$ & $\mathbf{s}$ \\
\hline \multirow[t]{4}{*}{$\mathrm{m} 1$} & high lingual anterolophid & $0 / 17$ & $0 / 10$ & 0 & - & $38 / 45$ & & + \\
\hline & ectomesolophid absent & $13 / 17$ & $6 / 10$ & 0.82 & - & $5 / 44$ & 25 & + \\
\hline & metalophulid absent & $6 / 16$ & $4 / 10$ & 0.016 & - & $35 / 44$ & 9.58 & + \\
\hline & short metalophulid & $10 / 16$ & $3 / 10$ & 2.6 & _ & $7 / 44$. & 12.54 & + \\
\hline \multirow[t]{3}{*}{$\mathrm{m} 2$} & mesolophid absent & $8 / 33$ & $2 / 17$ & 1.092 & - & $33 / 47$ & 16.4 & + \\
\hline & halflong or long mesolophid & $19 / 33$ & $15 / 17$ & 4.847 & - & $5 / 44$ & $12 . .6$ & + \\
\hline & posterior arm of protoconid connecting metaconid & $4 / 33$ & $1 / 17$ & 0.485 & - & $0 / 47$ & 5.99 & $+, 0,95$ \\
\hline \multirow[t]{4}{*}{ m3 } & metalophulid connecting anteroconid & $3 / 10$ & $3 / 12$ & 0.069 & - & $3 / 62$ & 7.13 & + \\
\hline & mesolophid absent & $10 / 10$ & $12 / 12$ & 0 & _ & $62 / 64$ & 9.59 & + \\
\hline & ectomesolophid absent & $9 / 11$ & $7 / 12$ & 1.495 & - & $63 / 64$ & 4.21 & - \\
\hline & posterior arm of protoconid reaching the lingual edge & $1 / 11$ & $2 / 12$ & 0.29 & - & $0 / 65$ & 5.99 & $+, 0,95$ \\
\hline \multirow[t]{4}{*}{ M1 } & mesolophe reaching the labial edge & $6 / 38$ & $2 / 10$ & 0.101 & _ & $14 / 39$ & 4.04 & - \\
\hline & single anterocone & $32 / 37$ & $8 / 9$ & 0.037 & - & $22 / 32$ & 3.17 & - \\
\hline & crest before paracone & $18 / 35$ & $2 / 10$ & 3.11 & - & $25 / 38$ & 1.55 & - \\
\hline & crest linking paracone and anterocone & $14 / 35$ & $1 / 10$ & 3.15 & _ & $15 / 38$ & 0.002 & _- \\
\hline \multirow[t]{2}{*}{ M2 } & lingual anteroloph surrounding protocone & $5 / 31$ & $1 / 5$ & 0.104 & _ & $33 / 53$ & 16.8 & + \\
\hline & two anterior transverse connections & $6 / 31$ & $2 / 5$ & 1.062 & - & $2 / 54$ & 5.66 & - \\
\hline
\end{tabular}

the upper part for $\mathrm{m} 2$. The single $\mathrm{m} 1 \mathrm{BJA763}$ is moderately worn. Its lingual anterolophid is strong and fully closes the very deep antesinusid. The labial anterolophid gradually extends to the base of the protoconid. The anterior arm of the protoconid (anterolophulid) is oblique and joins the anteroconid. The posterior arm of the protoconid is connected to the metaconid. There is no metalophid. The mesoconid has a very broad base, but there is no trace of mesolophid or ectomesolophid. On the lingual side, the trace of a crest remains behind the metaconid. The sinusid is wide open with no trace of labial cingulum. The posterolophid is widely connected to the entoconid.

The rest of the BoujacA material remains allocated to $P$. incertus. This material has been measured again after exclusion of the largest teeth (Table 4). Normality of the samples was controlled by the Shapiro-Wilk test (with values of W: $0.82<$ W $<0.96$ always exceeding the limit value). Tooth size of this small population was compared to that of $P$. incertus from Ehrenstein7 (Germany), but also to that of P. cornelii Freudenthal, 1994 of Mirambueno1 (Spain). Although precise comparison of dimensions of $P$. cornelii of MIR 1 with the population from BoujacA suffers from the reduced sample in the latter locality, the dental proportions remain comparable (Table 5). The differences concern the M2, $\mathrm{m} 1, \mathrm{~m} 2$ and $\mathrm{m} 3$, longer in BoujacA; these are significant, with $\mathrm{t}$-values that are less than 6 . The $\mathrm{m} 1, \mathrm{~m} 2$ and M2 are also wider, but the differences are weakly significant. With the same caution, the comparison between Mirambueno1 materials with that of BoujacA indicates that the M2 and $\mathrm{m} 2$, best represented molars in the latter locality, are significantly longer and wider. The dimensions of the $\mathrm{m} 1$ and the length of $\mathrm{m} 3$ of the species from BoujacA would also be stronger. In general terms, the differences are most pronounced between P. cornelii of MIR1 and the species of BoujacA, which indicate a slightly greater size for the latter.

The frequencies of morphological features were compared using the chi-square. Morphologically, the $\mathrm{m} 1$ from BoujacA differ very significantly from those of $P$. cornelii from Mirambueno1 by the absence of the characters "high anterolophid" and "absence of ectomesolophid" (Table 6; 7). In BoujacA, the posterior arm of the protoconid is connected to the metaconid on $\mathrm{m} 2$ and can reach 
TABLE 7. - Qualitative variation of characters between Pseudocricetodon incertus (Schlosser, 1884) from Mirambueno 4C and P. cornelii (Freudenthal, 1994) from Mirambueno 1 (from Freudenthal 1994).

\begin{tabular}{|c|c|c|}
\hline & Characters & $P$. incertus (Mirambueno $4 \mathrm{C}$ ) \\
\hline \multirow{6}{*}{$\begin{array}{l}\mathrm{m} 1 \\
\mathrm{~m} 2 \\
\mathrm{~m} 3 \\
\mathrm{M} 1\end{array}$} & $\begin{array}{l}\text { lingual anterolophid } \\
\text { ectomesolophid }\end{array}$ & $\begin{array}{l}\text { low or interrupetd }(8 / 10) \text {, sometimes absent }(2 / 10) \\
\text { frequently absent }(6 / 10) \text {, rarely strong }(2 / 10)\end{array}$ \\
\hline & mesolophid & better developed = more often halflong or long $(15 / 17)$ \\
\hline & posterior arm of protoconid & half times long: rarely reach lingual edge $(2 / 10)$ \\
\hline & anterocone & never clearly divided \\
\hline & crest before paracone & more often absent $(8 / 10)$, reaching anterocone rarely $(1 / 10)$ \\
\hline & Characters & P. cornelii (Mirambueno 1) \\
\hline \multirow{5}{*}{$\begin{array}{l}\mathrm{m} 1 \\
\mathrm{~m} 2 \\
\mathrm{~m} 3 \\
\mathrm{M} 1\end{array}$} & $\begin{array}{l}\text { lingual anterolophid } \\
\text { ectomesolophid }\end{array}$ & $\begin{array}{l}\text { never absent, sometimes low or interrupted }(7 / 45) \text {, most often high }(38 / 45) \\
\text { frequent }(39 / 44) \text {, often strong }(26 / 44)\end{array}$ \\
\hline & mesolophid & frequently absent $(33 / 47)$ \\
\hline & posterior arm of protoconid & never reaching lingual edge $(0 / 65)$ \\
\hline & anterocone & rarely two $(3 / 32)$ \\
\hline & crest before paracone & less often absent $(13 / 38)$, reaching anterocone more frequently $(15 / 38)$ \\
\hline
\end{tabular}

the lingual side of $\mathrm{m} 3$, while these characters are absent in P. cornelii. The development of the mesolophid of $\mathrm{m} 2$ is again comparable in these two localities.

\section{COMPARISONS AND DiSCUSSION ABOUT \\ PSEUDOCRICETODON POPULATIONS}

The size of the teeth of $P$. incertus from Mirambueno4C (MIR4C) and Saint-Privat-des-Vieux were compared using the t-test (Table 5). The difference between the dimensions of the M3 is only weakly significant (with a confidence coefficient of 95\%). The $\mathrm{m} 2$ length difference is also weakly significant $(t=2.7)$. The difference between the M1 lengths of the two localities disappears when excluding the large specimen SPV $23(2.11 \times 1.39 \mathrm{~mm})$. In addition, the distribution of the lengths of the M1 population of Saint-Privat-des-Vieux, by mean of Shapiro test, is normal (Shapiro-Wilk with $\mathrm{W}=$ 0984, above the limit values for risk 5\% [W = 0935] and $1 \%[\mathrm{~W}=0912])$. Otherwise, the dimensions of the tooth SPV23 fall outside those of the M1 of Pseudocricetodon landroveri. Therefore we keep the attribution of this tooth to $P$. incertus. Differences, including the length of M1, could thus result from the small sample from Mirambueno4C. The dimensions of most molars of $P$. incertus from Mirambueno4C and Saint-Privat-des-Vieux appear very similar with a possible trend of size increase of some of them in the Alès basin.
According to Freudenthal (1994: 20), P. cornelii from the younger locality MIR1 at Mirambueno (MP 27), with identical dimensions, differs from P. incertus from MIR4C in its morphology (Tables 7, 8). Frequencies of the distinctive features retained by Freudenthal (1994) as well as a few others are compared using the chi-square, for the populations of Saint-Privat-des-Vieux and MIR4C (P. incertus) on one hand, Saint-Privat-des-Vieux and MIR1 (P. cornelii) on the other. For M1, the characters that distinguish P. incertus (MIR4C) from P. cornelii (MIR1) are not significant. For all other morphological characters selected by Freudenthal, the population of Saint-Privat-de-Vieux does not show any difference with that of $P$. incertus of MIR4C, which however represents a small sample. However if one refers to the differential diagnosis (and M1 aside), significant differences appear allowing to separate the population of BoujacA with $P$. cornelii from MIR1: lingual anterolophid never high, ectomesolophid of $\mathrm{m} 1$ more frequently absent, mesolophid more frequent and better developed on $\mathrm{m} 2$, posterior arm of the protoconid reaching the lingual edge of $\mathrm{m} 3$. Finally, in terms of dimensions and of morphology, the populations of Pseudocricetodon incertus from Saint-Privat-des-Vieux (MP 26) in southern France and MIR4C (MP 26) in Spain are similar. They both differ from the population described as P. cornelii (Freudenthal 1994), from Mirambueno1 (MP 27). 
The species incertus was described by Dienemann (1987: 45-56, fig. 23) under the genus name Eucricetodon Thaler, 1969 from different localities in Germany, the species being particularly well represented in Ehrenstein 7 (MP 27). The comparison with the forms of BoujacA and Mirambuenol shows that the $\mathrm{m} 1$ from Ehrenstein 7 exhibits features of $P$. incertus (lingual anterolophid always low, almost complete absence of ectomesolophid) comparable to those from BoujacA, but also from Mirambueno4C and Saint-Privat-des-Vieux. The $\mathrm{m} 2$ of Ehrenstein 7 are different in having the posterior arm of the protoconid not connected to the metaconid (Dienemann 1987: fig. 23). The absence of mesolophid shows a comparable frequency in Ehrenstein 7 and BoujacA. This confirms the attribution of the population of BoujacA to P. incertus.

Thus, in two subcontemporaneous localities close to the MP 27 standard level, the frequency of character "mesolophid absent" (7/10 at BoujacA and 29/32 at Erhenstein 7) in P. incertus is of same order as that in P. cornelii of Mirambueno1 (33/47). The decrease in the frequency of the mesolophid on $\mathrm{m} 2$, which is $2 / 17$ at Mirambueno4C and $8 / 33$ at Saint-Privatdes-Vieux (MP 26), compared to its frequency at BoujacA and Ehrenstein7 (MP 27), may indicate a simplification of the tooth pattern over time. However, it is important to be cautious because the number of specimens is small in Mirambueno $4 \mathrm{C}$ and BoujacA. The lack of the character "posterior arm of the protoconid not connected to metaconid" in Ehrenstein 7, also suggests geographical variations affecting these subcontemporaneous populations.

Freudenthal (1994: 29) considered premature to establish a phylogeny of the three species $P$. incertus, $P$. cornelii and $P$. landroveri. However, he suggested that $P$. incertus could have given rise to $P$. cornelii with increasing complexity of teeth, whereas $P$. landroveri may not be the ancestor of the latter because of its size and its occurrence together with $P$. cornelii in Vivel del Rio (Spain, MP 28). The occurrence of $P$. aff. landroveri in BoujacA (MP 27) introduces a new step in this lineage, while that of $P$. incertus in this level invalidates the hypothesis of a direct filiation $P$. incertus-P. cornelii.

However, the differences noted between $P$. incertus from Saint-Privat-des-Vieux or Mirambueno4C
(MP 26) and P. cornelii from Mirambueno1 (MP 27) are less pronounced between $P$. incertus of BoujacA and Ehrenstein7 (MP 27) on the one hand and P. cornelii on the other hand. Thus $P$. cornelii could be a descendant of $P$. incertus or a geographical variant of this species, a hypothesis suggested by its differences with the contemporary populations from BoujacA and Ehrenstein7. However, the particular characteristics of $\mathrm{m} 1$ of P. cornelii ("high anterolophid" and "absence of ectomesolophid") are absent in all populations assigned to P. incertus whereas they occur in P. landroveri. Pseudocricetodon cornelii and P. landroveri, which coexist in the MP 26 and MP 27 levels, could have evolved in a parallel way from a common stock. Since $\mathrm{m} 1$ characters - like presence of high anterolophid and absence of ectomesolophid - occur in P. montalbanensis, this species may represent the stem species.

\section{Genus Eucricetodon Thaler, 1969}

TYPE SPECIES. - Eucricetodon collatus (Schaub, 1925) by monotypy.

Diagnosis. - "Differs from Pseudocricetodon by its greater size, the clearly bunodont teeth, the crests generally simple, the strongly reduced posterior lobe of lower $\mathrm{M} / 3$, and the convex labial edge of upper M1/. Anterocone of M1/ generally simple, occasionally tending to split somewhat. Posterior arm of the hypoconid more or less developed, occasionally lacking. Anteroconid always simple" (Vianey-Liaud 1972: 4).

\section{REMARK}

Beyond the successive discussions about the definition of the genus Eucricetodon (e.g., Comte 1985; Dienemann 1987; Freudenthal 1996; Hugueney 1999; de Bruijn et al. 2003; Kalthoff 2006; Gomes Rodrigues et al. 2013), it appears that the genus is probably polyphyletic, including various lineages.

Eucricetodon huerzeleri Vianey-Liaud, 1972

(Fig. 11A)

Holotype. - UM 501, maxillary fragment bearing M1-2, NHM, Basel.

TyPe LOCALITY. - Oensingen (Solothurn, Switzerland), MP 26. 
Diagnosis. — See Comte (1985: 12) for size and molars and for the enamel microstructure see Kalthoff (2006): primitive schmelzmuster, type 1 .

MATERIAL AND MEASUREMENTS (in mm). - One maxillary fragment (SPV165) bearing M1: $2.53 \times 1.68$ and M2: $1.80 \times 1.78$; M1 (SPV166): $2.72 \times 1.78$, M2 (SPV167): $2.01 \times 1.40$, one M2 and one $\mathrm{m} 2$ fragments (SPV168-169).

\section{DESCRIPTION}

Due to their large size, high crown and massive cusps with large wear facets, these teeth are referred to E. huerzeleri.

Gen. et sp. indet.

\section{DESCRIPTION}

A left maxillary fragment (SPV20; Fig. 11B) bears a well-worn M1 $(1.86 \times 1.43 \mathrm{~mm})$ the contour of which may be consistent with that of M1 of $P$. incertus. However, it differs by its greater width, slightly out of the limits of confidence (confidence 99\%) of the M1 ellipse data for the population of $P$. incertus from Saint-Privat-desVieux (Fig. 11C).

The distal end of the anterior palatine foramen is located at the anterior edge of M1. But this character alone does not support the assignment to the genus Pseudocricetodon (Vianey-Liaud 1974). For these reasons we leave this specimen in open nomenclature.

Genus Heterocricetodon Schaub, 1925

TyPE SPECIES. - Heterocricetodon stehlini Schaub, 1925 by monotypy.

\section{Heterocricetodon gaimersheimensis}

Freudenberg, 1941

(Fig. 12)

Holotype. - Fragment of right lower jaw, bearing m1-3, BSP 1939 XI 4, BSPG, Munich.

Type locality. - Gaimersheim (South Germany), MP 27-28.
Original diagnosis. — See Freudenberg (1941: 105). Description and variability of teeth of the type-population: Kristkoiz (1992: 63-72).

Measurements (in mm). - Eight isolated teeth: $1 \mathrm{M} 1$ (2.54 × 1.66), $3 \mathrm{M} 2(2.12 \times 1.94,2.17 \times 1.86,1.94 \times$ $1.79), 1 \mathrm{M} 3(1.72 \times 1.54), 1 \mathrm{~m} 1(2.65 \times 1.60), 1 \mathrm{~m} 2$ $(2.54 \times 1.47), 1 \mathrm{~m} 3(2.37 \times 1.78)$.

\section{DESCRIPTION}

M1. The anterior arm of the protocone and the mesoloph join the labial edge of the tooth, like on several specimens from Gaimersheim.

M2-M3. There is a double connecting of the anterior cusps (complete metalophule I and II) and the mesoloph reaches the labial edge of the teeth, as it happens on some specimens from Gaimersheim.

$\mathrm{m} 1$. The two mesolophids are short, like it is often the case in the type population.

$\mathbf{m} 2$. The posterior arm of the protoconid is short but exceeds the mesolophid length, extending towards the metaconid, as for some specimens from Gaimersheim.

$\mathbf{m} 3$. The posterior arm of the protoconid is long and joins the labial edge of the tooth, at the base of the metaconid ridge.

\section{DISCUSSION}

Four species of relatively large size have been referred to this genus. Among them, H. stehlini Schaub, 1925, H. schlosseri (Schaub, 1925) and H. helbingi Stehlin \& Schaub, 1951, remain poorly defined. Hugueney (1980), in her discussion about the species of Heterocricetodon from Saint-Menoux, has suggested that the variations between the three species stehlini, schlosseri and helbingi could enter a unique species, when more material would be known. Concerning H. gaimersheimensis Freudenberg, 1941, Engesser (1987) supposed that "the material from Gaimersheim described by Freudenberg includes two species, $H$. stehlini and $H$. helbingi". Later, an extensive study has been achieved by Kristkoiz (1992). 
A1

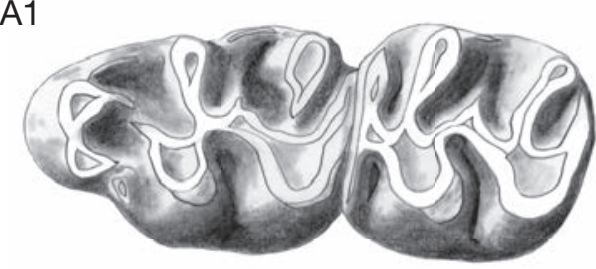

A2

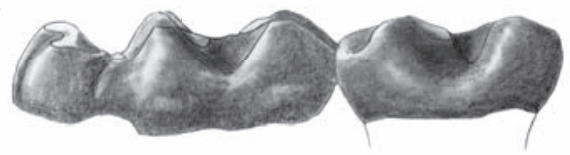

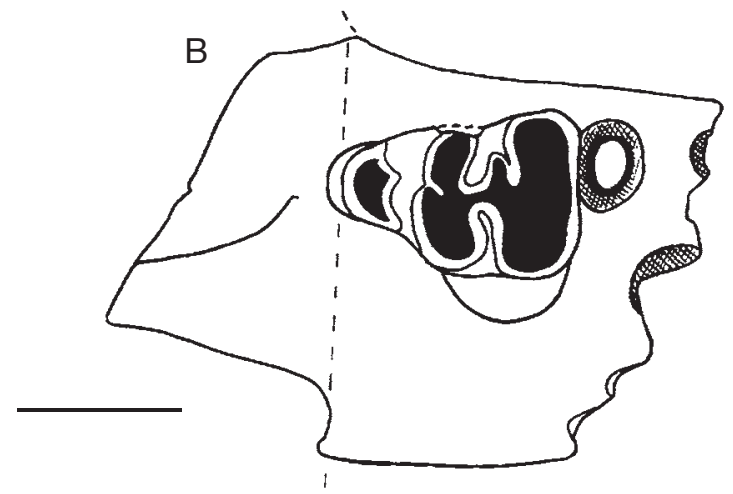

C

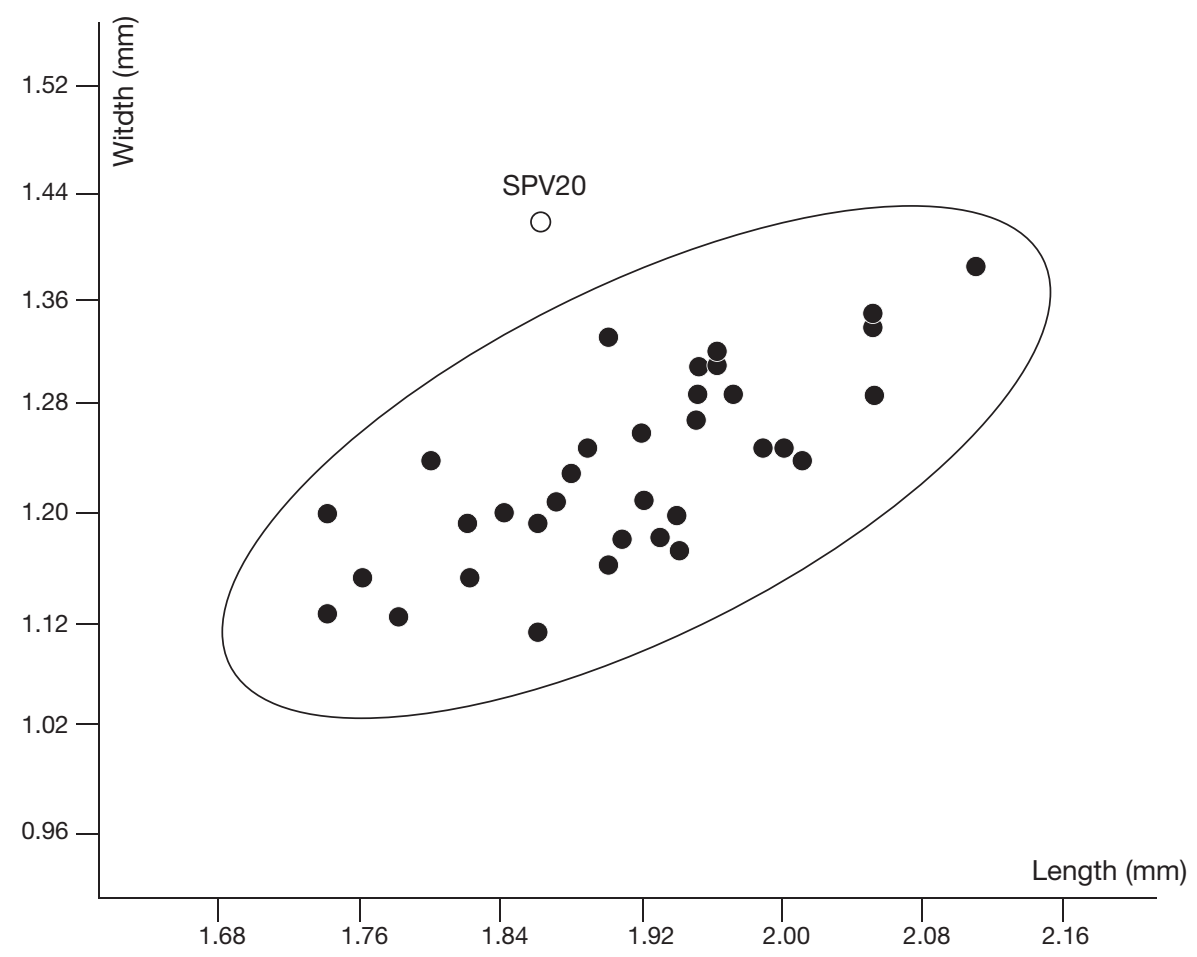

FIG. 11. - Other cricetids from Saint-Privat-des-Vieux (Gard; Lower Chattian, MP 26): A, Eucricetodon huerzeleri Vianey-liaud, 1972 , left M1-M2 (reversed), SPV165: A1, occlusal view, A2, lingual view; B, Cricetidae indet., fragment of left maxillary with M1, SPV20, occlusal view; C, bivariate (Length and Width) diagram of M1 of Pseudocricetodon incertus (Schlosser, 1884) from Saint-Privat-desVieux. The open circle represents the M1 SPV20. The plots for the M1 of $P$. incertus are surrounded by their calculated equiprobable ellipse. Scale bar: $1 \mathrm{~mm}$.

He established the presence of only one species although with a great variability in the abundant material from Gaimersheim. Therefore, H. stehlini and $H$. helbingi could be two morphotypes within $H$. gaimersheimensis and $H$. gaimersheimensis
Freudenberg, 1941 would be a junior synonyme of H. stehlini Shaub, 1925. However, the species H. stehlini is based on an isolated lower jaw from an undetermined locality from Quercy ("Bach", Old collections). 

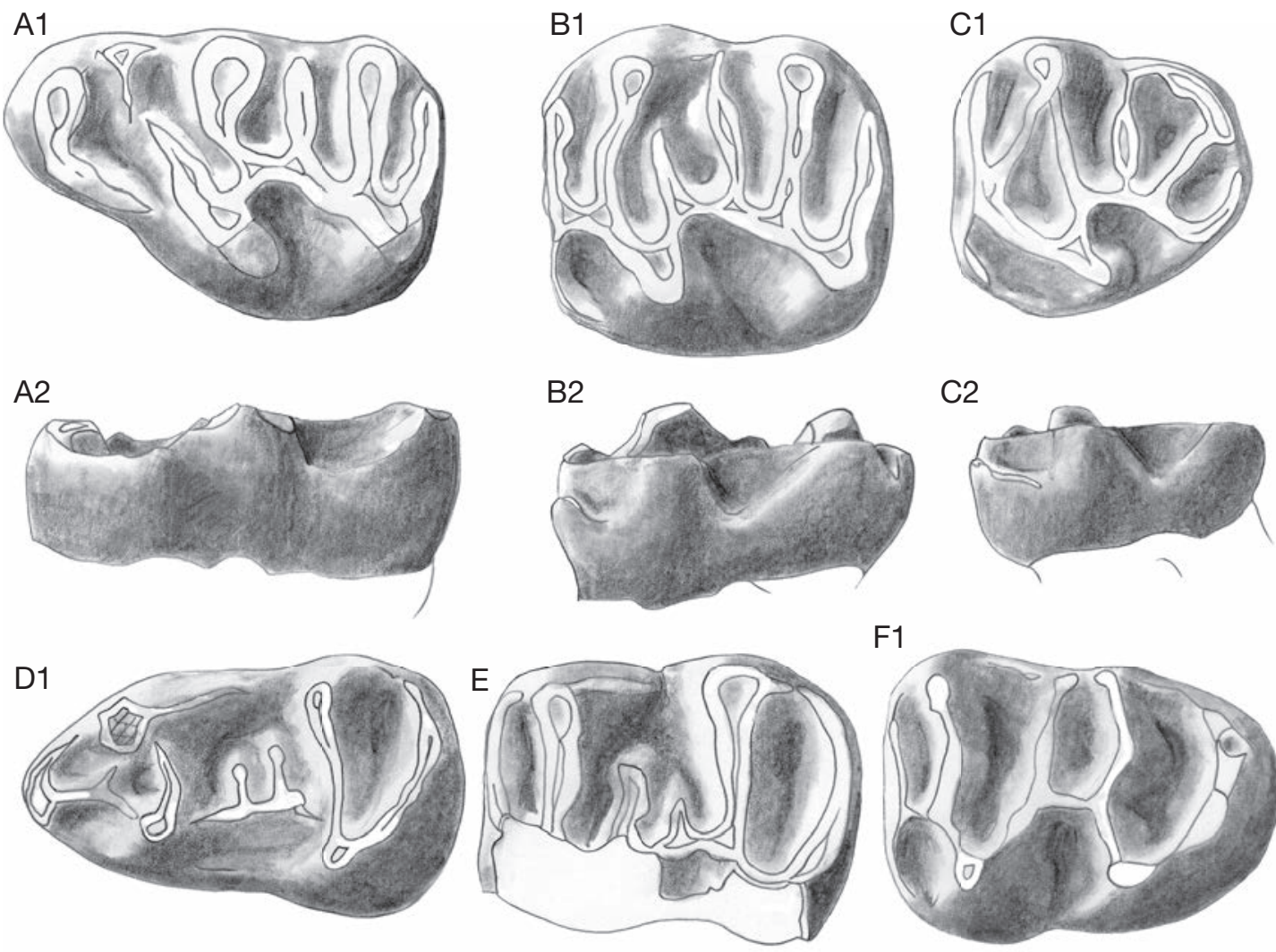

$\mathrm{F} 1$
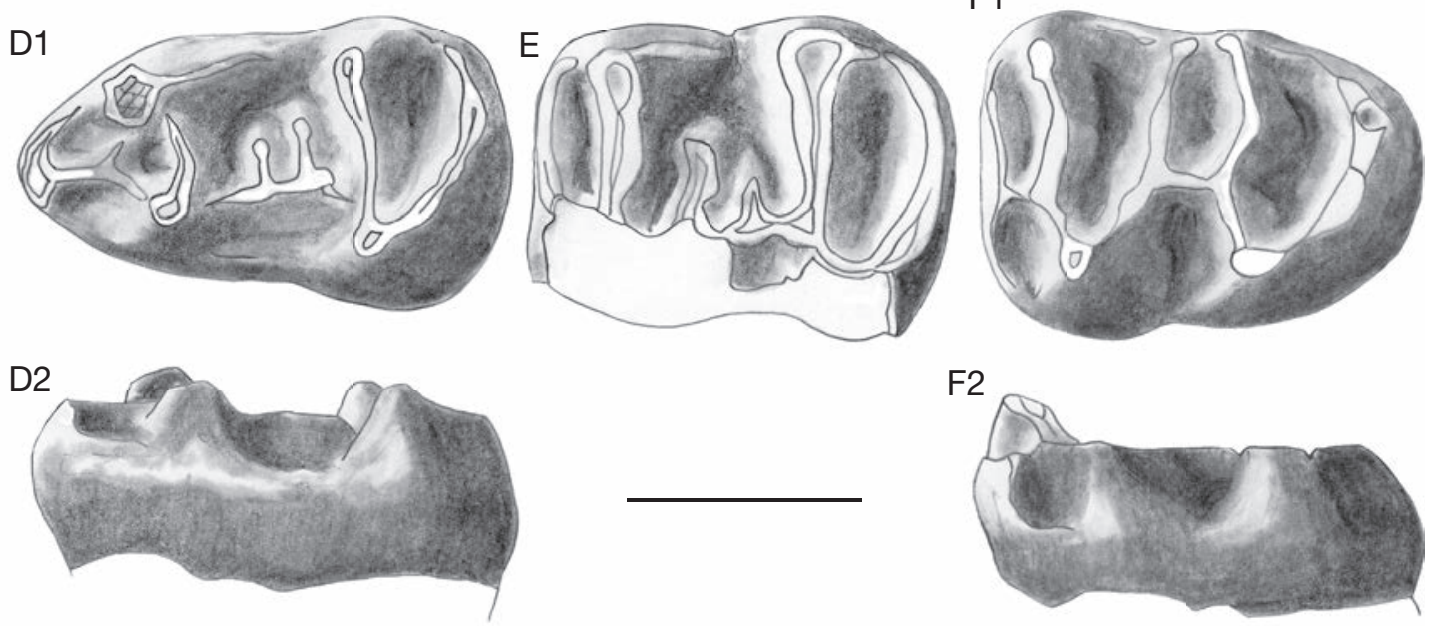

FIG. 12. - Heterocricetodon gaimersheimensis Freudenberg, 1941, from Saint-Privat-des-Vieux (Gard; Lower Chattian, MP 26): A, right M1 (reversed), SPV170: A1, occlusal view, A2, lingual view; B, left M2, SPV171: B1, occlusal view, B2, lingual view; C, right M3 (reversed), SPV174: C1, occlusal view, C2, lingual view; D, right m1 (reversed), SPV175: D1, occlusal view, D2, lingual view; E, left m2, SPV178, occlusal view; F, left m3, SPV179: F1, occlusal view, F2, lingual view. Scale bar: $1 \mathrm{~mm}$.

Morphological and dimensional variations of the material of Saint Privat-des-Vieux fall within those of H. gaimersheimensis, and are not completely similar with the type of $H$. stehlini. The teeth from SaintPrivat-des-Vieux are thus reported to $H$. gaimersheimensis; because it is the only one species whose variability is known until now. It is the same for a few teeth from Sarèle (Vianey-Liaud 1972) and BoujacA.
Family GLIRIDAE Thomas, 1897

Genus Gliravus Stehlin \& Schaub, 1951

TYPE SPECIES. — Gliravus priscus Stehlin \& Schaub, 1951 by monotypy. 

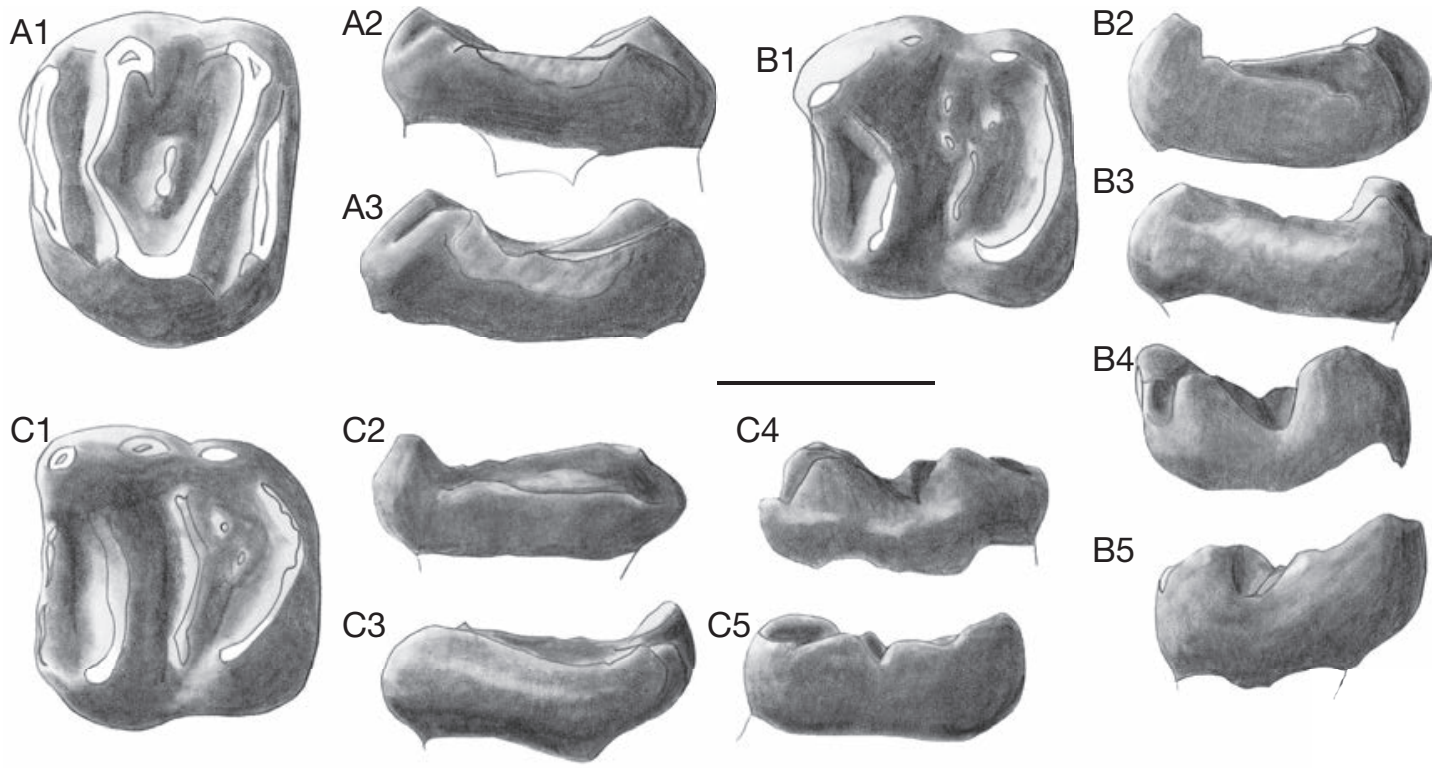

B5

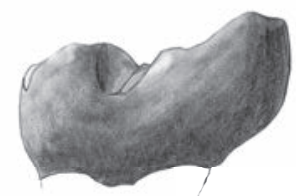

FIG. 13. - Gliravus bruijni Hugueney, 1967, from Saint-Privat-des-Vieux (Gard; Lower Chattian, MP 26): A, right M1-2, SPV192: A1, occlusal view, A2, distal view, A3, mesial view; B, left m1-2, SPV196: B1, occlusal view, B2, mesial view, B3, distal view, B4, labial view, B5, lingual view; C, left m1-2, SPV195: C1, occlusal view, C2, mesial view, C3, distal view, C4, labial view, C5, lingual view. Scale bar: $1 \mathrm{~mm}$.

\section{Gliravus bruijni Hugueney, 1967}

(Fig. 13)

SYNONYMY. - See Vianey-Liaud et al. (1995).

Holotype. — Left M/2, no. 96182, Lyon 1 University.

TYPE LOCALITY. - Coderet (Allier, France), MP 30.

DiAGNOSIS. - " Gliravus with teeth significantly larger than those of G. majori Stehlin \& Schaub, 1951, and G. tenuis, Bahlo, 1975, smaller than those of G. bravoi Hugueney et al., 1985, and size close to that of $G$. daamsi, Bosma \& de Bruijn, 1982. Differs from the other Gliravus species by the absence of mesoconid and the reduced mesolophid; mesolophid occasionally connected to the hypoconid. Centrolophs generally reduced, and very low when present" (Vianey-liaud 1994: 133, translated from French).

MATERIAL AND MEASUREMENTS (in mm). - Two M1-2: SPV192: $1.23 \times 1.50$, SPV193: 1.12-1.40; three m1-2: SPV194: $1.24 \times 1.29$, SPV195: $1.28 \times 1.39$, SPV196: $1.22 \times 1.39$.

\section{DESCRIPTION}

Teeth size and morphological characters fall into the variations of those of Gliravus bruijni Hugueney,
1967, as described from different localities where the species occurs (e.g., Hugueney 1967; VianeyLiaud 1994; Vianey-Liaud et al. 1995).

M1-2 pattern is simple, with a single centroloph, and the lingual ends of anteroloph and posteroloph swollen and well separated from the protocone. On $\mathrm{m} 1-2$, the mesoconid is absent.

Family EOMYIDAE Depéret \& Douxami, 1902

Genus Eomys Schlosser, 1884

TYPE SPECIES. — Eomys zitteli Schlosser, 1884 by monotypy.

\section{REMARKS}

The few eomyid teeth are assigned to Eomys based on their uninterrupted mure or ectolophid, contrary to Eomyodon Engesser, 1987, Rhodanomys Depéret \& Douxami, 1902 or Pseudotheridomys Schlosser, 1926, and on the well-marked cusps contrary to the three latter genera. 
Eomys aff. zitteli Schlosser, 1884

(Fig. 14A-D)

Material AND MEASUREMENTS (in mm). - One P4 SPV180: $0.92 \times 0.99$; one M1-2 SPV181: $0.86 \times 1.08$; one p4 SPV185: $1.00 \times 0.89$; one ml-2 SPV184: $1.04 \times$ 1.09; one digested lower tooth row m1-m3 SPV183.

\section{DESCRIPTION AND DISCUSSION}

These isolated teeth are brachydont. P4 has a weak antesinus, a reduced anterosyncline due to the direct connection of the paracone nearly to the labial end of the anteroloph, and a short mesoloph. On M1-2, the protoloph is present and the anterosyncline longer than in $\mathrm{P} 4$. The mesoloph is halflong.

Teeth are of greater size than those of Eomys antiquus Aymard, 1853. The size of the two molars falls into the variations of the small population of Eomys aff. zitteli from Mas-de-Pauffié (Comte \& Vianey-Liaud 1987), the two premolars being a little smaller. The morphology of the teeth of Saint Privat-des-Vieux is also close to that seen in Eomys zitteli.

A fragment of a left dentary bearing m1-3 is much damaged, pecularly $\mathrm{m} 1$. It belongs to a species of smaller size (notably its width) than Eomys zitteli. The measurements $(\mathrm{m} 1:[0.99 \times 0.71 \mathrm{~mm}]$; $\mathrm{m} 2:[0.97 \times 0.90 \mathrm{~mm}] ; \mathrm{m} 3:[0.81 \times 0.83 \mathrm{~mm}])$ are of the same order as those of the corresponding teeth in Eomys antiquus and Eomys minor Comte \& Vianey-Liaud, 1987. The occurrence of a form close to Eomys zitteli (supposed to be derived from Eomys antiquus) at Saint Privat-des-Vieux as well as at Mas-de-Pauffié, would lead to refer this small form to another species, Eomys minor. However, the presence of a long mesolophid on $\mathrm{m} 2$ does not match the morphology (no mesolophids) of the type of Eomys minor. As the variability of the latter is obviously unknown, we could refer the specimen of Saint Privat-des-Vieux to Eomys minor, known in the locality Belgarric1 (Tarn-etGaronne, MP 25) and La Blache (Maridet et al. 2010), but it could better represent an extreme variant of $E$. aff. zitteli.

However, new eomyids were collected in Mas-dePauffié: two upper teeth $(\mathrm{M} 2[0.79 \times 1.09 \mathrm{~mm}]$ and M3 $[0.77 \times 0.98 \mathrm{~mm}]$; Fig. $14 \mathrm{E}, \mathrm{F})$ can be more clearly referred to Eomys minor. Their sizes are compatible with that of the lower teeth of E. minor. The mesoloph is short on M2, and this morphology can correspond to lower molars without mesolophid; such upper teeth are also described from La Blache.

Family SCIURIDAE

(Fischer von Waldheim, 1817) Gray, 1821

Genus Comtia Vianey-Liaud, n. gen.

Diagnosis. - That of the type-species.

SPECIES INCLUDED. - C. bernardi n. sp.; ?C. giganteus (Freudenberg 1941).

Comtia bernardi Vianey-Liaud, n. sp. (Fig. 15A)

ETymology. - Dedicated to the late Bernard Comte. HolotyPe. — Right M?1 (SPV190), Coll. UM2.

Type LOCALITY. - Saint-Privat-des-Vieux (Gard, France), lower Chattian (MP 26).

DiAgnOSIS. - Squirrel of large size (M1-2: $\mathrm{L} \times \mathrm{w}=$ $3.4 \times 4.02 \mathrm{~mm}$ ); lingual flank of the tooth higher than the labial one. Cusps high and acute (parastyle, paracone, mesostyle, metacone, small hypocone and protocone); one small paraconule, two metaconules stronger than the paraconule; straight protoloph and metaloph higher than the anterior and posterior cinguli; enamel slightly wrinkled all along the cusps and lophs as well as in the basins. Differs from:

- Oligopetes Heissig, 1979, in the absence of postparacrista connected to the mesostyle and the well marked paraconule and metaconules;

- Paracitellus Dehm, 1950, in the connection of the paraloph and metaloph to the protocone, and in the absence of labial connection between parastyle-paraconemesostyle-metacone and posteroloph;

- Miopetaurista Kretzoi, 1962, or Forsythia Mein, 1970, in its non-crescentic cusps;

- Blackia Mein, 1970, in the presence of conules, and the less wrinkled enamel.

Material AND measurements (in $\mathrm{mm}$ ). - A single isolated right upper molar has been collected at SaintPrivat-des-Vieux. SPV190 M? $1: \mathrm{L} \times \mathrm{w}=3.4 \times 4.02$, protocone height $=2.48$, paracone and metacone height $=1.95$. 

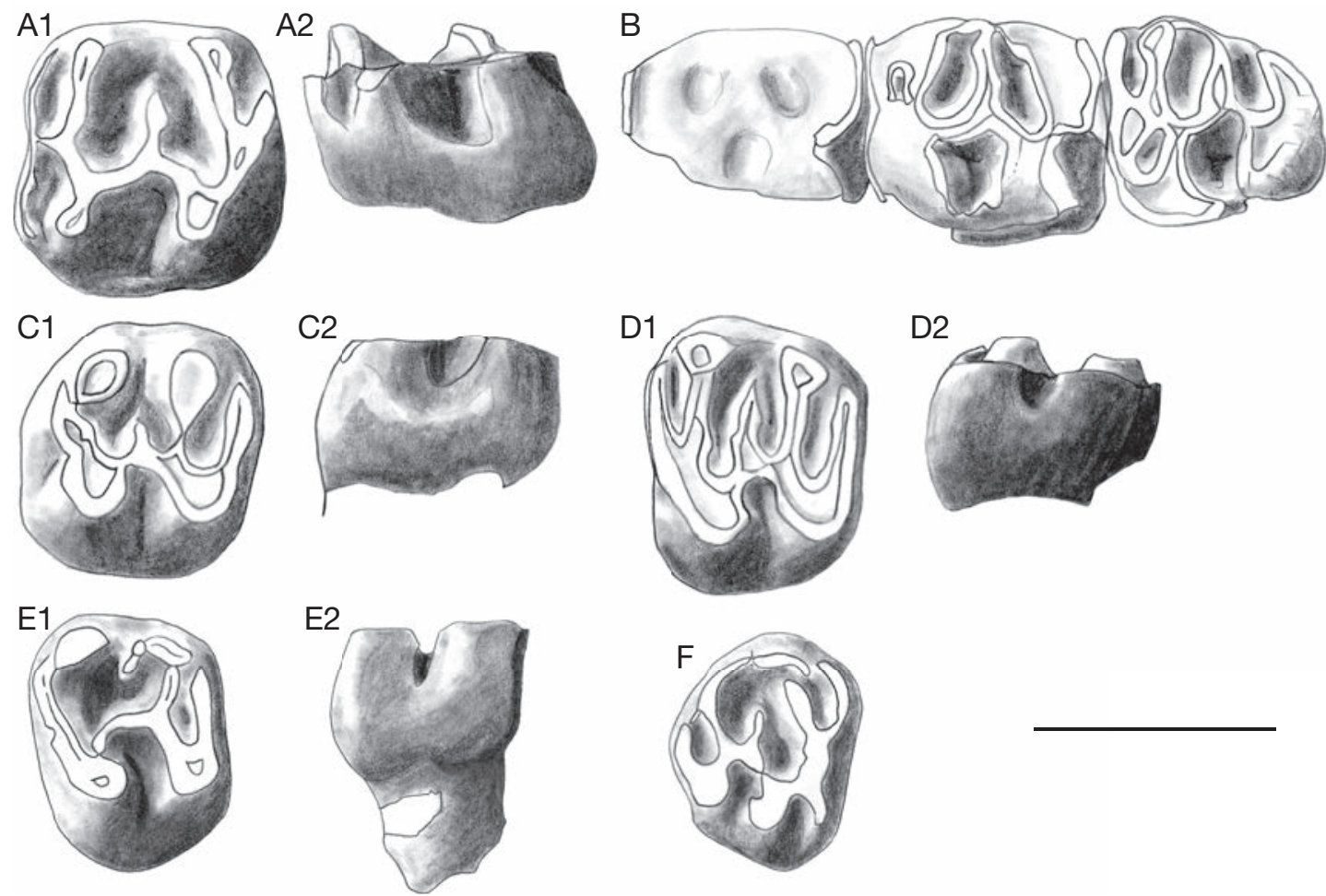

FIG. 14. - Eomys aff. zitteli Schlosser, 1884, from Saint-Privat-des-Vieux (Gard; Lower Chattian, MP 26): A, left m1-2, SPV184, (drawing reversed): A1, occlusal view, A2, labial view; B, digested and worn m1-m3, SPV183, occlusal view; C, left P4, SPV180: C1, occlusal view, C2, lingual view; D, left M1-2, SPV181: D1, occlusal view, D2, lingual view; E, F, Eomys minor Comte \& Vianey-Liaud, 1987, from Mas-de-Pauffié (Lot; Lower Chattian, MP 26): E, left M2, MPF215: E1, occlusal view, E2, lingual view; F, right M3, MPF216, occlusal view. Scale bar: $1 \mathrm{~mm}$.

\section{DESCRIPTION}

This unworn molar has well-individualized cusps. The anterior cingulum runs from the base of the protocone to the anterior flank of the paracone which it is connected by a low ridge. It has a bulbous parastyle. The hypocone is small, but well protruding at the lingual end of the posterior cingulum. The hypocone is connected to the distal end of the protocone through a low endoloph. The metacone is a little smaller than the paracone. The mesostyle is also bulbous, developed in the middle of the valley between the two labial cusps. It extends lingually by a short mesoloph. The protoloph is connected transversely to the anterior arm of the protocone. It displays one well distinct protoconule, and a weak other one, the more pronounced being the most labial. The metaloph is connected to the rear of the protocone in front of the endoloph anterior end. It is slightly oblique relative to the protoloph. It has two metaconules, wider than the protoconules. The labial metaconule is the most marked. Both lophs with their conules are lower than the main cones and styles, which are prominent. A short and low spur descends from the top of the protocone labially in the median valley of the tooth.

The entire crown is relatively high, the lingual flank of the protocone + hypocone being the highest. Enamel is slightly crenulated on the surface of the valleys and transverse lophes, but without clear-cut crestules.

\section{DISCUSSION}

Even if the material is restricted to one tooth, we decided to describe a new taxon because it is easy 
to distinguish this form from the other large Oligocene and lower Miocene squirrels. One lower m3 of close size $(\mathrm{L}=4.07 \mathrm{~mm}, \mathrm{l}=3.41 \mathrm{~mm})$ is known from Pech Desse (Quercy, MP 28a), but its crown is clearly lower $(\mathrm{H}$ of metaconid $=1.79 \mathrm{~mm}$, strongly overhanging the other cuspids and the low talonid basin) and the cuspids less acute.

Another large sciurid is summarily reported as "Sciurus" giganteus in Freudenberg (1941) and Werner (1994) from the lower Miocene of Eckingen (Southern Germany). Only $2 \mathrm{~m} 3$ (4.20 × 4.06 and $4.09 \times 4.00)$ and $1 \mathrm{M} 3(3.53 \times 3.74)$ are known. This species shares wrinkled enamel with Comtia bernardi Vianey-Liaud, n. gen., n. sp. The wrinkles seem more numerous in the former. It is difficult to compare the M3 of Freudenberg with our M1-2, mainly the height of the protocone and other cusps, the shape and number of buccal cusps and their mesio-distal connections, the occurrence of conules. This species is tentatively included in the genus Comtia n. gen. We keep provisionaly the two species: bernardi and giganteus, waiting for more material and information.

A slightly smaller upper teeth is described as ?Ratufa sp. from Ulm-Westtangente by Werner (1994: 171). It differs from the M1-2 from SaintPrivat-des-Vieux in its clearly lower crown, its less prominent cusps, especially the hypocone, the absence of metaconules, its smooth enamel.

Some teeth of a large Sciuridae from an Oligocene Turkish locality (Kocayarmalar) have been attributed to the flying squirrels Petauristinae Brandt, 1855 and with doubt to Miopetaurista, by de Bruijn \& Ünay (1989). Thorington et al. (2005) discussed the difficulties to identify fossil flying squirrels on the basis of dental morphology alone, considering many cases of convergent evolution. Therefore, we assign the species of Saint-Privat-des-Vieux, represented by a single tooth, to the family Sciuridae without further details.

Slightly smaller than the one of Saint-Privat-desVieux, the teeth from Kocayarmalar exhibit some similarities to it, such as the central mesostyle, separated both from paracone and metacone, the lingual mesoloph indicated by an outgrowth in the central basin (here drawn lingually by a spur from the protocone and labially by a marked ridge from the mesostyle) and by the low hypocone. The strong wear on teeth from Kocayarmalar makes them difficult to compare. However, some significant differences can be pointed, highlighting the strong metaconule, while the labial swellings of the metaloph are lower, in contrast to what occurs at Saint-Privat-des-Vieux. Despite the wear, accessory ridges from the mesostyle and metacone are well marked and the enamel surface is smooth (de Bruijn \& Ünay 1989: figs 10, 11). There are no particular indications on the height of the crown for the Turkish material.

Otherwise, being of the same size as the large Miocene Miopetaurista and Albanensia DaxnerHöck \& Mein, 1975, the tooth from Saint-Privatdes-Vieux differs from them by a bunodonty more pronounced, the hypocone shorter, the protoloph and metaloph less convergent, and the crenulations of enamel seemingly more attenuated.

\section{NOMENCLATURAL REMARK}

This new species must be referred to "Comtia bernardi Vianey-Liaud, 2014", following the article 50.1 and the "recommendation $50 \mathrm{~A}$ concerning multiple authors" of the International Code of Zoological Nomenclature (ICZN 1999: 52, 182).

Family cf. APLODONTIDAE Trouessart, 1897

Gen. et sp. indet.

Material EXAMINED. - Two small fragments of lower molars (SPV187-188) and one small fragment of an upper molar (SPV189).

\section{DESCRIPTION AND DISCUSSION}

These fragments are tentatively referred to an undetermined aplodontid. The incompleteness of these fragments makes difficult their orientation and homologies. Nevertheless, some characters are found on the three fragments: presence of accessory ridges, cusps weakly prominent, merged in vertical ridges and crescentic cusps.

\section{SPV187 (Fig. 15B)}

The edge of the crown is high, and two acute high cuspids emerge: one, crescentic, is probably the protoconid; it is connected to the anterolophid. 

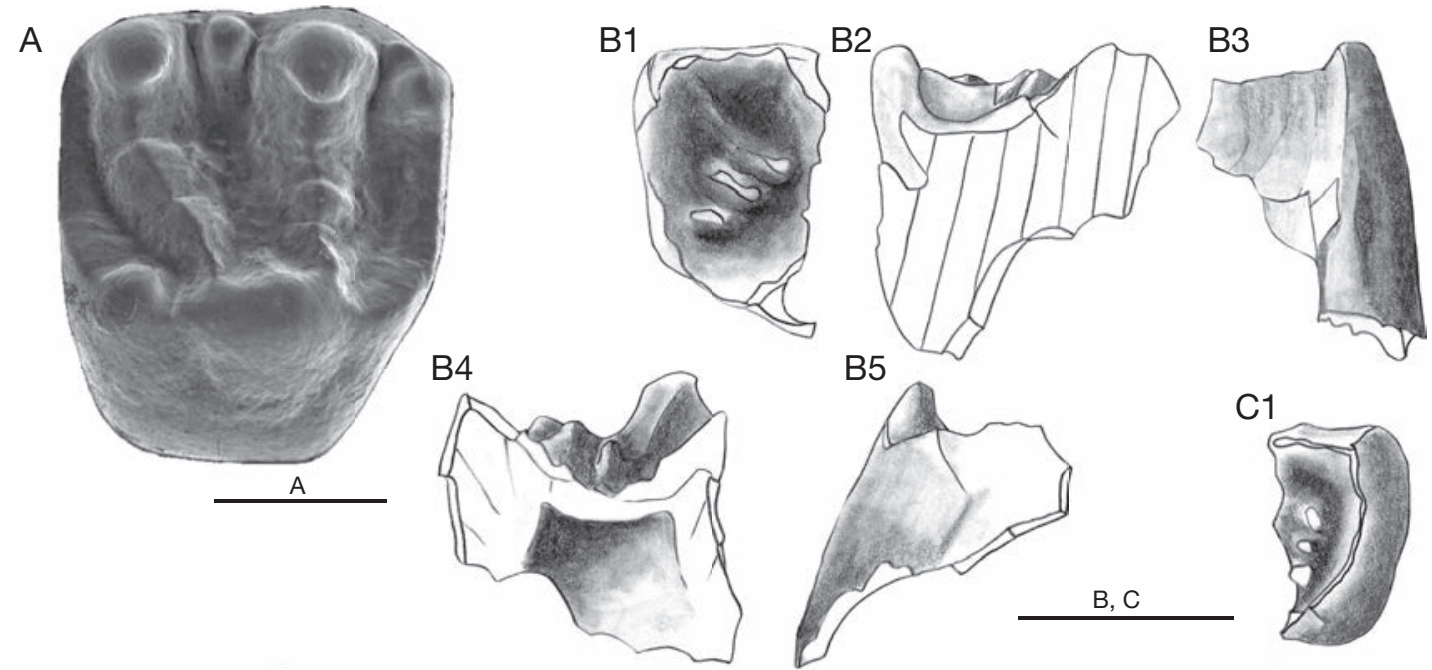

C1
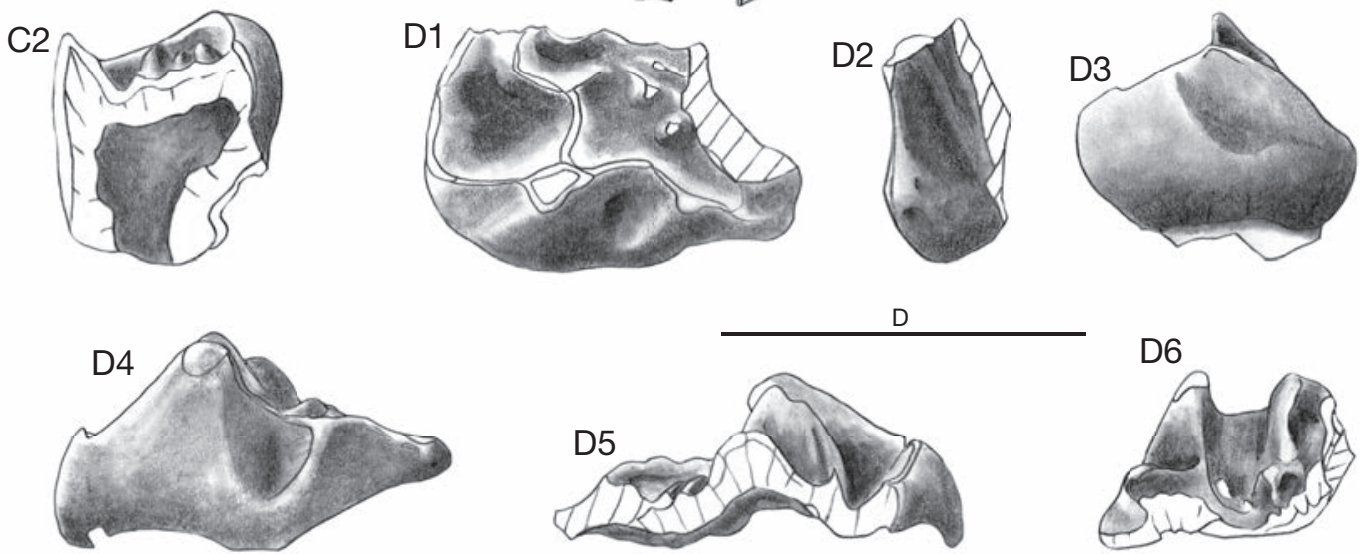

FIG. 15. - A, Comtia bernardi Vianey-Liaud, n. gen., n. sp., right M1-2, from Saint-Privat-des-Vieux (Gard; Lower Chattian, MP 26), SPV190, occlusal view; B-D, ? cf. Aplodontidae indet. B, SPV187, anterior fragment of lower molar: B1, occlusal, B2, mesial, B3, lingual, B4, distal, B5, labial; C, SPV188, posterior? fragment of lower molar: C1, occlusal, C2, mesial, C3, lingual, C4, distal; D, SPV189, fragment of upper tooth: D1, occlusal, D2, lingual, D3, labial, D4, distal. Scale bars: A, $1.5 \mathrm{~mm}$; B-D, $1 \mathrm{~mm}$.

The other is the metaconid, prolonged posteriorly in a high, narrow and vertical metastylid crest. In between, there are three short oblique ridges, parallel to a low fold descending from the metaconid tip.

This anterior fragment of an ? $\mathrm{m} 2$ differs from Parallomys macrodon (Schmidt-Kittler \& VianeyLiaud, 1979), and also from the different species of Allomys Marsh, 1877 (e.g., Rensberger 1983). In these species, the accessory ridges are connected to the anterolophid whereas they are well separated here. The lingual wall is flat and vertical, and the metastylid crest is horizontal and nearly as high as the metaconid, whereas it lowers mesio-distally quite steeply in P. macrodon and Allomys.

\section{SVP188 (Fig. 15C)}

This fragment of a lower teeth is probably a posterior fragment as the crown appears less high posteriorly than anteriorly as observed in $P$. macrodon. The entoconid is weakly prominent; a weak steep-edge is at the angle formed at the entoconid-posterolophid junction. The basin is relatively shallow, like on SVP187, and contains three small and low accessory cusps, free from the posterolophid. 
TABLE 8. - Comparisons of characters (chi²) of Pseudocricetodon incertus (Schlosser, 1884) from MP 26 and P. cornelii from MP 27. Abbreviations: f, frequency; MIR1, Mirambueno 1; MIR 4C, Mirambueno 4C; SPV, Saint-Privat-des-Vieux.

\begin{tabular}{|c|c|c|c|c|c|c|c|c|}
\hline \multicolumn{2}{|c|}{ species of Pseudocricetodon } & \multicolumn{4}{|c|}{ P. incertus } & \multirow{2}{*}{\multicolumn{3}{|c|}{$\begin{array}{c}\text { P. cornelii } \\
\text { MIR1 }\end{array}$}} \\
\hline & \multirow[b]{2}{*}{ Characters } & \multirow{2}{*}{$\frac{\text { SPV }}{f}$} & \multicolumn{3}{|c|}{ MIR4C } & & & \\
\hline & & & $\mathbf{f}$ & chi $^{2}$ & $\mathbf{s}$ & $\mathbf{f}$ & chi $^{2}$ & s \\
\hline \multirow[t]{4}{*}{$\mathrm{m} 1$} & high lingual anterolophid & $0 / 17$ & $0 / 10$ & 0 & - & $38 / 45$ & & + \\
\hline & ectomesolophid absent & $13 / 17$ & $6 / 10$ & 0.82 & - & $5 / 44$ & 25 & + \\
\hline & metalophulid absent & $6 / 16$ & $4 / 10$ & 0.016 & - & $35 / 44$ & 9.58 & + \\
\hline & short metalophulid & $10 / 16$ & $3 / 10$ & 2.6 & - & $7 / 44$. & 12.54 & + \\
\hline \multirow[t]{3}{*}{$\mathrm{m} 2$} & mesolophid absent & $8 / 33$ & $2 / 17$ & 1.092 & - & $33 / 47$ & 16.4 & + \\
\hline & halflong or long mesolophid & $19 / 33$ & $15 / 17$ & 4.847 & - & $5 / 44$ & $12 . .6$ & + \\
\hline & $\begin{array}{l}\text { posterior arm of protoconid connecting } \\
\text { metaconid }\end{array}$ & $4 / 33$ & $1 / 17$ & 0.485 & - & $0 / 47$ & 5.99 & $+, 0,95$ \\
\hline \multirow[t]{4}{*}{ m3 } & metalophulid connecting anteroconid & $3 / 10$ & $3 / 12$ & 0.069 & - & $3 / 62$ & 7.13 & + \\
\hline & mesolophid absent & $10 / 10$ & $12 / 12$ & 0 & - & $62 / 64$ & 9.59 & + \\
\hline & ectomesolophid absent & $9 / 11$ & $7 / 12$ & 1.495 & - & $63 / 64$ & 4.21 & - \\
\hline & $\begin{array}{l}\text { posterior arm of protoconid reaching } \\
\text { the lingual edge }\end{array}$ & $1 / 11$ & $2 / 12$ & 0.29 & - & $0 / 65$ & 5.99 & $+, 0,95$ \\
\hline \multirow[t]{4}{*}{ M1 } & mesolophe reaching the labial edge & $6 / 38$ & $2 / 10$ & 0.101 & - & $14 / 39$ & 4.04 & - \\
\hline & single anterocone & $32 / 37$ & $8 / 9$ & 0.037 & - & $22 / 32$ & 3.17 & - \\
\hline & crest before paracone & $18 / 35$ & $2 / 10$ & 3.11 & - & $25 / 38$ & 1.55 & - \\
\hline & crest linking paracone and anterocone & $14 / 35$ & $1 / 10$ & 3.15 & - & $15 / 38$ & 0.002 & - \\
\hline \multirow[t]{2}{*}{ M2 } & lingual anteroloph surrounding protocone & $5 / 31$ & $1 / 5$ & 0.104 & - & $33 / 53$ & 16.8 & + \\
\hline & two anterior transverse connections & $6 / 31$ & $2 / 5$ & 1.062 & - & $2 / 54$ & 5.66 & \\
\hline
\end{tabular}

\section{SVP189 (Fig. 15D)}

The occurrence of small cusps / ridges in one of the basins, as well as the narrow cusps, linked by crescentic ridges support the attribution of this specimen to the same species as the fragments of lower teeth. However, due to its incompleteness, even the orientation of the fragment of this upper tooth is problematic. The highest cusp could be the protocone, and it is linked to a low cingulum (anterior), and also to a lower and narrower cusp that could be the hypocone. But, if so, the arrangement of the other cusps is not clear. Two crescentic cusps are parallel to the "protocone", the first (paraconule?) being connected to it by a low ridge, and only a slice of the second one (paracone?) is preserved (Fig. 15D3). The accessory ridges are low in a shallow basin.

\section{Order ARTIODACTYLA Owen, 1841 Family CAINOTHERIIDAE Camp \& VanDerHoff, 1940}

Genus Plesiomeryx Gervais, 1873

TYPE SPECIES. - Plesiomeryx cadurcensis Gervais, 1873 by monotypy.
Plesiomeryx indet.

MATERIAL EXAMINED. - Left DP3; one fragment of right upper molar (SPV650).

\section{DESCRIPTION}

The very small size of these remains of Cainotheriidae allows to refer them to the genus Plesiomeryx Gervais, 1876, that is common in most "middle" Oligocene localities from Quercy (Sudre 1995).

\section{Genus Caenomeryx Hürzeler, 1936}

Type sPeCies. - Caenomeryx procommunis (Filhol, 1877) by monotypy.

\section{Caenomeryx indet. cf. communis} (Filhol, 1877)

Material eXamined. - Right lower jaw fragment with alveoli of p1, p2 and p3 and p4 well preserved; one upper right $\mathrm{P} 4$. 


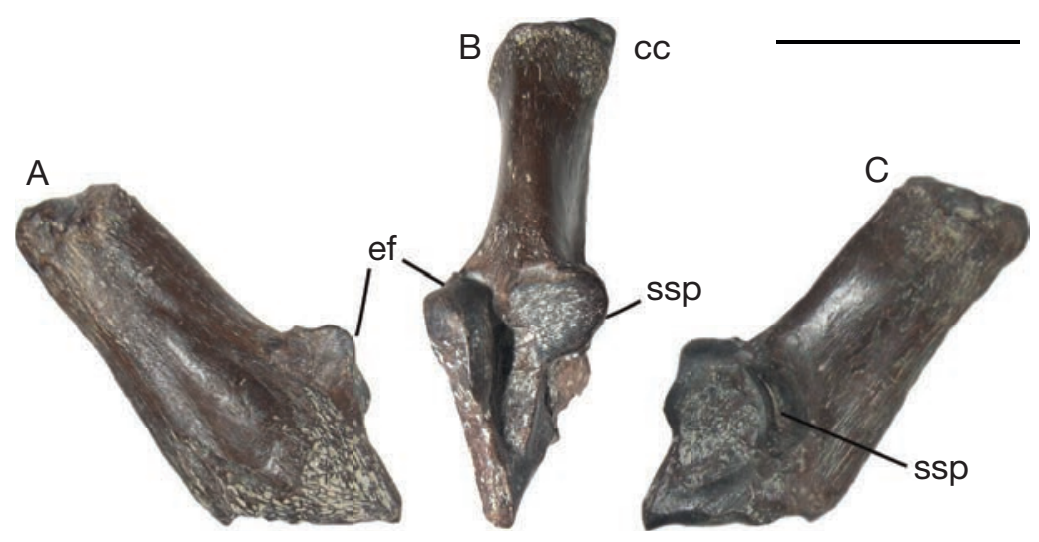

FIG. 16. - Right calcaneus of Lophiomeryx cf. chalaniati Pomel, 1853, from Saint-Privat-des-Vieux (Gard; Lower Chattian, MP 26), SPV700. A, lateral side; B, dorsal aspect; C, medial side. Abbreviations: ef, ectal facet; cc, caput calcanei; ssp, sustentacular process. Scale bar: $2.5 \mathrm{~cm}$.

\section{DESCRIPTION}

This mandible, on which there is no diastema between $\mathrm{p} 1$ and $\mathrm{p} 2$, is close to specimens referred to C. communis (Filhol, 1877). Its dimensions are similar to those of this species, identified in older localities (Blondel 2005), and most abundant in the mid Oligocene deposits from Quercy (Sudre 1995). As seen in this species, the P4 has the protocone situated forward, the parastyle and metastyle highly developed and a strong oblique ridge at the base of the ectoloph.

Family LOPHIOMERYCIDAE Janis, 1987

Genus Lophiomeryx Pomel, 1853

TYPE SPECIES. - Lophiomeryx chalianati Pomel, 1854 by monotypy.

\section{Lophiomeryx cf. chalaniati Pomel, 1854}

MATERIAL EXAMINED AND MEASUREMENTS (in mm). - O One left P4: $10.4 \times 10.7$; one left p3, $12.6 \times 5$; talus, $\mathrm{L}=61$.

\section{DESCRIPTION AND COMPARISONS}

The P4, almost as long as wide, is remarked by its incipient molarization. Indeed, on the flat but slightly concave ectoloph, the outer cusp begins to divide. The postprotocrista shows a particularly clear median bifurcation. The anterior cingulum is short and strong. The posterior cingulum, very strong also, stands up to the mid of the posprotocrista. Size and morphology of this specimen are the closest to those of the P4 of Lophiomeryx cf. chalaniati from Le Garouillas (Sudre 1995). Among the rich material from this locality, some P4 show an early bifurcation of the postprotocrista, and a beginning of division of the outer cusp. However, none has a degree of molarization as advanced as that observed on the tooth of Saint-Privat-des-Vieux. This morphology is unknown in other selenodont artiodactyls from the mid-Oligocene confirming the more derived state of this form. The $\mathrm{p} 3$, very elongated and provided with a longitudinal ridge, has morphology consistent with that of $L$. cf. chalaniati from Le Garouillas (Sudre 1995: fig. 14a, b).

A calcaneus is also reported to this form (Fig. 16). The body is massive with a wide caput calcanei and the sustentaculum tali projecting medially and very thick rearwardly; the tendinous slide is flat medio-laterally and rounded dorsoventrally. The morphology of the surface suggests the important role of the tensio flexor of the phalanges. This is a configuration similar to that observed in the calcaneus of Lophiomeryx from Le Garouillas (Sudre 1995: 231, fig. 16), the latter being slightly smaller $(\mathrm{L}$ mean $=58.6 \mathrm{~mm})$; the size of the specimen from Saint-Privat-des-Vieux exceeds 
the maximum value recorded in the form of Le Garouillas. On the basis of the material of $L$. chalaniati from Le Garouillas, the distal ends of the appendicular skeleton of this species show short and robust metapodials, and metatarsals nearly as long as the metacarpals (Sudre 1995). These features characterize a walking animal, and the species is probably dependent on soft soils, close to aquatic environments (Trofimov 1957; Blondel 1998). The paleoecological study of the fauna from Le Garouillas suggests such an environmental context (Legendre 1995).

With regard to the largest mammals known from Saint-Privat-des-Vieux, we can estimate the weight of the animal as about $25 \mathrm{~kg}$ if one refers to that established for $L$. cf. chalaniati from Le Garouillas (Legendre 1995; Martinez \& Sudre 1997).

The chronological extension of the lineage of Lophiomeryx, initiated at the beginning of the Oligocene (L. mouchelini, at Villebramar, MP 21; Brunet \& Sudre 1987) lasts up to the level MP 28. The last representative of the lineage is known from the site of Pech-Desse (MP 28a; Blondel 1996). The dental elements referred to the species chalaniati from localities more recent than Le Garouillas does not allow meaningful comparisons.

Family BACHITHERIIDAE Janis, 1987

Genus Bachitherium Filhol, 1882

TYPe SPeCiEs. - Bachitherium curtum (Filhol, 1877) by monotypy.

Bachitherium indet.

Material AND MEASUREMENTS (in $\mathrm{mm}$ ). - Right P4, SPV690: $6.5 \times 8.2$; a trigonid of a left lower molar, SVP691.

\section{DESCRIPTION AND COMPARISONS}

The P4 is smaller than that of Lophiomeryx. The protocone is crescentiform; the external cusp is massive and provided with a small pillar, while the wing of the parastyle projects labially. This character set evokes those of the P4 of Bachitherium (Geraads et al. 1987: 53, fig. 6).
The lower molar trigonid differs from that of the Lophiomeryx molar in having a well-developed preprotocristid, approximately symmetrical with the postmetacristid; the metaconid is labio-lingually compressed (Geraads et al. 1987: 59, figs 26, 31).

Although the size of these specimens is similar to that of Bachitherium medium Filhol, 1882 (excluding B. insigne Filhol, 1882), the material of Saint-Privat-des-Vieux is not diagnostic at a species level because several lineages of the genus coexist in the middle Oligocene, especially in MP 25 (Sudre 1995: 251, fig. 41). The last known species of Bachitherium, B. lavocati Sudre, 1986, from PechDesse (MP 28a; Blondel 1997) is a smaller form than that of Saint-Privat-des-Vieux (Sudre 1986).

Order HYAENODONTIDA Van Valen, 1967

\section{Genus Thereutherium Filhol, 1876}

TyPe AND SINGLE SPECIES. - Thereutherium thylacodes Filhol, 1876 by monotypy; from Quercy (Old Collections, missing precise locality).

\section{Thereutherium thylacodes Filhol, 1876}

HoLOTYPE. - MNHN.F.QU8588, anterior part of skull with left and right C-M2 (Filhol 1877: figs 194-196).

DistRibUtion AND AGE. - France only: Quercy ("old collections" and, for the recent, well-dated localities Itardies and Le Garouillas), Saint-Privat-des-Vieux; Oligocene, from MP 23 to MP 26 for the material from the well-dated localities.

Material AND MEASUREMENTS. - Distal fragment of right M1 (SPV621). Length of the metastyle (from the carnassial notch to the distal rim) $=1.85 \mathrm{~mm}$; height of the paracone (greatest distance between the cusp tip to the dentine/enamel junction) $=2.95 \mathrm{~mm}$; angle between the metastyle and a line connecting the tip of the paracone to that of the metacone $=123^{\circ}$.

\section{COMMENTS}

Filhol (1876) created the species based on a single specimen. The brief description of this specimen ("[...] face avec le maxillaire inférieur en place et toutes les dents"; Filhol 1876: 289) does not 


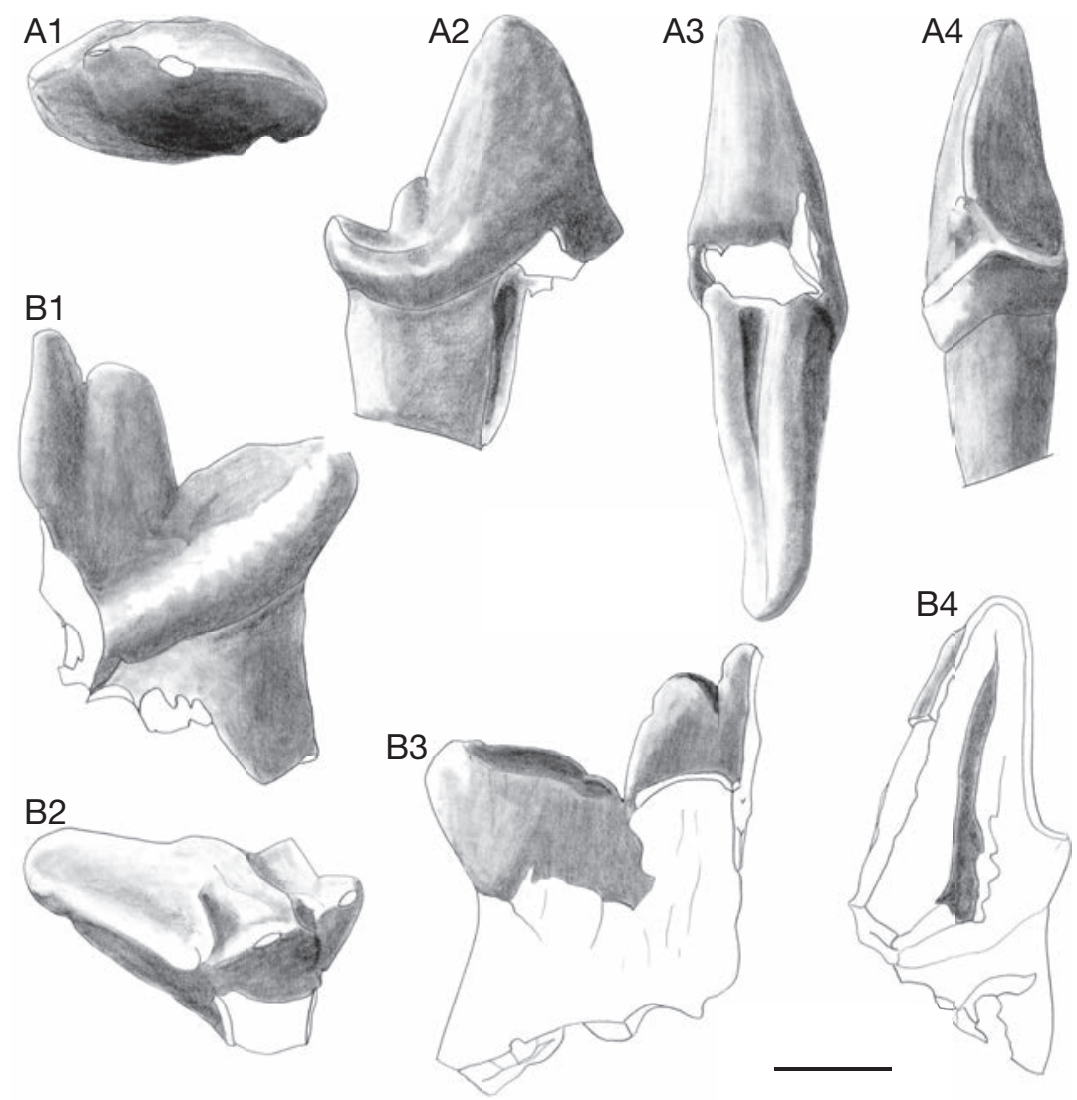

FIG. 17. - Carnivors from Saint-Privat-des-Vieux (Gard; Lower Chattian, MP 26). A: Carnivora Gen. and sp. indet. cf. Palaeogale sp., fragmentary left p3, SPV680: A1, occlusal view, A2, labial view, A3, mesial view, A4, distal view; B, Thereutherium thylacodes Filhol 1876, distal fragment of right M2, SPV681: B1, labial view, B2, occlusal view, B3, lingual view, B4, mesial view. Scale bar: $1 \mathrm{~mm}$.

make easy its precise identification in the collections. According to Lange-Badré (1979: 171), "Il est probable que la pièce Qu 8588 du M.N.H.N., portant la mention "type", est effectivement celui de Filhol, bien que la mandibule n'y soit plus associée. C'est en tout cas le spécimen qu'a choisi cet auteur pour le figurer (1877, fig. 189-196)". This definition of the name-bearing type needs some revisions, however. Indeed, in Filhol (1877), the figures 189 to 196 refer to three different specimens: two fragments of hemimandibles, MNHN.F.QU8592 (Filhol 1877: fig. 190, 191, 193) and MNHN.F.QU8583 (Filhol 1877: fig. 189, 192), and the anterior part of skull with the upper dentition, MNHN.F.QU8588 (figs 194-196, where the incisors row, said to be unpreserved by Filhol, is shown reconstructed). The two fragments of hemimandibles (MNHN.F.QU8592, MNHN.F.QU8583) are from two distinct individuals and there is no evidence (size, wearing pattern, or preservation state) that one of them belongs to the same individual as MNHN.F.QU8588. In his contribution, Filhol (1877: 222) states that he possesses three specimens documenting the lower dentition, while he provides illustrations of only two of them. In 1877, he, then, had only in hands three more or less completely preserved hemimandibles and a single upper dentition. If the latter (MNHN.F.QU8588) certainly belongs to the individual on which Filhol based the 
species in 1876, none of the three fragmentary hemimandibles studied by Filhol in 1877 can be confidently identified as "le maxillaire inférieur en place et toutes les dents" that he mentioned earlier (Filhol 1876) when he created the species. MNHN.F.QU8593 is the only of the two figured fragmentary hemimandibles to preserve a complete cheektooth row, but we know nothing about the third lower dentition mentioned by Filhol (1877). The lower dentition of the holotype individual cannot be identified.

\section{DESCRIPTION}

The specimen (Fig. 17B) preserves the metastyle, the metacone and a part of the paracone that includes the cusp tip. The metastyle is much lower than the metacone-paracone. The crowns of the two latter cusps are fused along most of their height; their tips remain well separated and a labial groove is still visible on the labial face. The paracone, the mesial part of which is not preserved, is taller than the metacone. A shallow notch is present between the metastyle and the metacrista.

\section{COMPARISON AND DISCUSSION}

The size and morphology of this fragmentary tooth support its assignment to T. thylacodes, one of the smallest known hyaenodontids (same size as the extant carnivoran Mustela putorius). The specimen of Saint-Privat-des-Vieux is fragmentary, allowing only the length of the metastyle and the height of the paracone to be measured and compared to those of M1 from Quercy stored in the MNHN (material from the old collections and a few specimens from Itardies, MP 23). The length of the metastyle is lesser than in the material from the old collections of Quercy (2.17-2.35; $\mathrm{n}=3)$, but it is similar to that of the metastyle of the only available M1 from Itardies (ITD $573=1.87$ ). The height of the paracone is also lesser than in the material from the old collections ( 3.17 and $3.28 \mathrm{~mm}$ for the two specimens on which this cusp is preserved and not heavily worn), but it is greater than in ITD 573 (2.69; paracone slightly worn, however). Overall the individuals from Itardies are smaller-sized than those from the old collections. Morphologically, the specimen of Saint-Privat-des-Vieux cannot be dis- tinguished from the material from the Quercy. The paracone and the metacone are slightly less fused in Saint-Privat-des-Vieux M1 than in the holotype MNHN.F.QU8588, but this is also observed in other specimens from Quercy (e.g., MNHN.F.QU8590, MNHN.F.QU.ITD573).

Thereutherium was assigned to the Limnocyonidae Wortman, 1902 (Lange-Badré 1979, 1995) before Morlo \& Gunnell (2003) excluded it from this family. According to these authors, the presence, in T. thylacodes, of strong cingulids on premolars, the reduction of the metaconid on the lower molars and of the metacone on the upper molars may indicate a closer relationships to the Apterodontinae Szalay, 1967 (especially the genera Apterodon Fischer, 1880 and Quasiapterodon Lavrov, 1999) than to any other hyaenodontid subfamily. Such a close relationship must be strengthened, however, because T. thylacodes possesses more derived characters such as the loss of $\mathrm{M} 3 / \mathrm{m} 3$ and a nearly complete fusion of the metacone and paracone on M1. The phylogenetic position of T. thylacodes remains uncertain and shall be addressed by including this genus in a wider phylogenetic framework.

So far, the species was known only from Quercy. It is scarce in collections compare to other creodonts. The known material is essentially from old, imprecisely-dated collections from Quercy (a relatively abundant material is known, for example, in the collections of the MNHN and of the Naturhistoriches Museum, Basel). A few specimens (stored in the MNHN) were recently discovered from Itardies (MP 23; Lange-Badré 1979) and Le Garouillas (MP 25; Lange-Badré 1995). The specimen from Saint-Privat-des-Vieux is significant by extending both the stratigraphic (now, until MP 26) and geographic distributions of $T$. thylacodes.

Order CARNIVORA Bowdich, 1821

Gen. et sp. indet.

$$
\text { cf. Palaeogale sp. }
$$

Material and MEASUREMENTS (in $\mathrm{mm}$ ). - Probably a left $\mathrm{p} 3$ missing its mesial base, SPV620 (L of the preserved fragment $=2.58 ; \mathrm{w}=1.25 ; \mathrm{L} / \mathrm{w}=2.06 ; \mathrm{Ht}=2.14 \mathrm{~mm}$ ). 


\section{DESCRIPTION}

The crown is narrow and nearly symmetrical. There is a small accessory cuspid located labially at the distal basis of the main cuspid. The talonid is elongated, tapers backward and displays a low, longitudinal, medially-located crest.

\section{COMPARISON AND DISCUSSION}

Although fragmentary, this premolar cannot be assigned to Thereutherium thylacodes. It differs from the premolars, and especially from $\mathrm{p} 3$, of this hyaenodont in lacking a cingulid and in having an elongated talonid. Although the $\mathrm{p} 3$ of Thereutherium thylacodes is similar in length and in heigth $(\mathrm{L}=2.64-2.97$ for $\mathrm{N}=8 ; \mathrm{Ht}=1.81-2.40$ for $\mathrm{N}=$ 7 ), it is proportionally wider (width $=1.42-1.65$ for $\mathrm{N}=8 ; \mathrm{L} / \mathrm{w}=1.77-1.93$ ). If this tooth really is a p3, it belongs to an animal of approximately the size of the smallest species of the genus Palaeogale von Meyer, 1846, such as P. felina (Filhol 1877). It differs in some details such as a less asymmetrical crown, less trenchant crests and the basal position of the distal accessory cuspid. The specimen from Saint-Privat-des-Vieux resembles more the p3 of larger, geologically younger species of Palaeogale, such as P. praehyaenoides Morlo, 1996, of the early Miocene from the Mainz Basin (Germany; Morlo 1996). However, the assignment of the specimen of Saint-Privat-des-Vieux remains uncertain pending further material is found.

\section{RESULTS AND DISCUSSION}

\section{TAPHONOMY AND ENVIRONMENT}

A first study has been published in Bonnet et al. (2011: 12, pls I, II). The fossil assemblage includes freshwater (Cyprinidae) or amphibious vertebrates (rare crocodilians, diversified and well-preserved amphibians). The discoglossids (either Discoglossus or Latonia) and the ranid Pelophylax do not live permanently in the water but they did not move away, the presence of water must be permanent. Among large mammals, Lophiomeryx was probably living on the banks of a swamp.

On the contrary, the lizard Pseudeumeces seems to have been adapted to relatively dry environments, which is not inconsistent with the local presence of water. There are also burrowing taxa (amphisbaenians) that were probably not able to install their burrows too close to the water. The presence of the most abundant terrestrial elements (rodents Issiodoromys and Pseudocricetodon) seems to be the result of the accumulation of owl pellets, and their short transport. Issiodoromys, with its leaping locomotor adaptation, and its hypsodont teeth is a marker of open environments (e.g., Vianey-Liaud 1976, 1979).

The other rodents and micromammals are rare, and relatively well-preserved, which implies a short transport of these fossils. Macromammals are small to medium size, and very rare. As the excavation of the site was related to the installation of a pipeline, the amount of sediment processed was limited to a few hundred kilograms. This could explain the small number of macromammal remains and their low diversity.

\section{SYSTEMATIC RESULTS}

For some taxa, the quality of material does not allow sharp developments. However, for some of them, evolutionary stages hitherto unknown are described: it is the case for two rodents and the Hyaenodontida Thereutherium thylacodes. Two rare species of rodents are documented. A very fragmentary one is a possible Aplodontidae that appears as different from the known Oligocene selenodont taxa, such as: Paransomys VianeyLiaud, Gomes Rodrigues \& Marivaux, 2012, Plesispermophilus Filhol, 1882, Parallomys Korth, 1992 or Allomys Marsh, 1877. The other one is a large sized Sciuridae; even if only an upper molar is known, we have decided to erect a new taxon, Comtia bernardi Vianey-Liaud, n. gen., n. sp., as its characters are clearly distinguishable from all the other Oligocene sciurids. The bat Cuvierimops sp. represents a more derived stage than the species from Le Garouillas (MP 25), and therefore a new species. The familial assignment of the snake Platyspondylia is discussed.

For others, we bring new data on their occurrence, their characters or/and variability. Among rodents, the data provided by the theridomyids and cricetids are the most relevant. The populations of Issiodoromys pauffiensis and Protechimys major are compared 
TABLE 9. - List of mammals in six western European localities dated from MP 26 (Saint-Privat-des-Vieux [SPV], Gard, France; StM, Saint-Menoux, Allier, France; MPF, Mas-de-Pauffié, Lot, France; StH/StA, Saint-Henri/Saint-André, Bouches-du-Rhône, France; Oen11, Oensingen 11; MüH, Mümliswil-Hardberg, Solothurn, Switzerland).

\begin{tabular}{|c|c|c|c|c|c|c|}
\hline & SPV & StM & MPF & StH/StA & Oen11 & MüH \\
\hline MARSUPIALIA & 1 & 1 & 2 & 1 & 2 & 1 \\
\hline Amphiperatherium exile & & & & & cf. & \\
\hline Amphiperatherium minutum & & & $x$ & & cf. & \\
\hline Peratherium elegans & cf. & cf. & $x$ & & & $x$ \\
\hline Peratherium sp. & & & & $x$ & & \\
\hline PLACENTALIA & & & & & & \\
\hline ARTIODACTYLA & 4 & 4 & 4 & 6 & 4 & 6 \\
\hline Doliochoerus quercyi & & $x$ & $x$ & $x$ & & \\
\hline Anthracotheridae indet. & & & & & $x$ & \\
\hline Anthracotherium sp. & & & & $x$ & & \\
\hline Anthracotherium cuvieri & & $x$ & & & & \\
\hline Plesiomeryx indet. & $x$ & & $x$ & & & \\
\hline Plesiomeryx cadurcensis & & & & & $x$ & \\
\hline Caenomeryx procommunis & & cf. & & & & \\
\hline Caenomeryx communis & cf. & & & & & \\
\hline Calnotheriidae indet. & & & $x$ & & & $x$ \\
\hline Lophiomeryx chalaniati & cf. & & & & & $x$ \\
\hline Elomeryx borbonicus & & & & $x$ & & \\
\hline Bachitherium insigne & & cf. & & $x$ & $x$ & $x$ \\
\hline Bachitherium indet. & $x$ & & & & & \\
\hline Bachitherium curtum & & & $x$ & $x$ & & \\
\hline Metriotherium mirabile & & & & $x$ & & $x$ \\
\hline Iberomeryx sp. & & & & & & $x$ \\
\hline Metriotherium sp. & & & & & $x$ & \\
\hline Propalaeochoerus sp. & & & & & & $x$ \\
\hline LIPOTYPHLA & 1 & 4 & 3 & 3 & 7 & 3 \\
\hline Heterosoricinae indet. & & $x$ & & & & \\
\hline Paratalpa sp. & & & & & $x$ & \\
\hline Talpidae indet. & & & $\times$ & $x$ & & \\
\hline Talpid cf. Desmanella & & & & & $x$ & \\
\hline Mygatalpa arvernensis & & cf. & & & & \\
\hline Geotrypus antiquus & & & cf. & & & \\
\hline Geotrypus arambourgi & & cf. & & & & \\
\hline Geotrypus sp. & & & & & $x$ & \\
\hline cf. Geotrypus & $x$ & & & & & $x$ \\
\hline Tetracus sp. & & & & & & $x$ \\
\hline Necrogymnurus cayluxi & & & $x$ & & cf. & aff. \\
\hline Necrogymnurus mediterraneus & & $x$ & & $x$ & & \\
\hline Crocidosorex sp. & & & & & $x$ & \\
\hline Plesiosorex sp. & & & & & $x$ & \\
\hline Dinosorex huerzeleri & & & & cf. & aff. & \\
\hline CHIROPTERA & 1 & 1 & 11 & 0 & 1 & 1 \\
\hline Chiroptera indet. & & & & & & $x$ \\
\hline Vespertilionidae indet. & & $x$ & $x$ & & & \\
\hline Myotis salodorensis & & & & & $x$ & \\
\hline Vespertiliavus sp. & & & $x$ & & & \\
\hline Taphozous sp. & & & $x$ & & & \\
\hline Embanolluridae sp. & & & $x$ & & & \\
\hline Vaylatsia sp. & & & $x$ & & & \\
\hline Palaeophyllophora sp. & & & $x$ & & & \\
\hline Palaeophyllophora quercyi & & & cf. & & & \\
\hline Hipposideros (Pseudorhinolophus) sp. & & & $x$ & & & \\
\hline Hipposideridae sp. 1 and 2 & & & $x \times$ & & & \\
\hline Cuvierimops sp. & $x$ & & $\times$ & & & \\
\hline PERISSODACTYLA & 0 & 1 & 0 & 3 & 1 & 1 \\
\hline Rhinocerotid indet. & & & & & $x$ & \\
\hline Protaceratherium albigense & & $x$ & & $x$ & & \\
\hline
\end{tabular}


TABLE 9. - Continuation.

\begin{tabular}{|c|c|c|c|c|c|c|}
\hline & SPV & StM & MPF & StH/StA & Oen11 & MüH \\
\hline Ronzotherium romani & & & & $x$ & & \\
\hline Ronzotherium sp. & & & & & & $x$ \\
\hline Diaceratherium massiliae & & & & $x$ & & \\
\hline RODENTIA & 10 & 13 & 11 & 13 & 21 & 16 \\
\hline Gliravus bruijni & $x$ & $x$ & $x$ & & & \\
\hline Gliravus bravoi (? = G. bruijni) & & & & & cf. & \\
\hline Gliravus majori ( $(?=$ G. garouillensis $)$ & & & & & cf. & cf. \\
\hline Microdyromys praemurinus & & $x$ & & & sp. & \\
\hline Peridyromys sp. & & & & & $\times$ & \\
\hline Bransatoglis sp. & & & & & $x$ & \\
\hline Glirudinus praemurinus & & & & cf. & & \\
\hline Glirudinus sp. & & & & & $x$ & \\
\hline Oligodyromys planus & & $x$ & & cf. & & \\
\hline Eomys zitteli & aff. & $x$ & $x$ & $x$ & & \\
\hline Eomys molassicus & & & & & $x$ & $x$ \\
\hline ?Eomys minus & & & $x$ & & & \\
\hline Eomys sp. & & & & & & $x$ \\
\hline Eucricetodon sp. 1, 2 & & & & $x$ & $x$ & \\
\hline Eucricetodon huerzeleri & $x$ & aff. & $x$ & & $x$ & $x$ \\
\hline Eucricetodon huberi & & & $x$ & & $x$ & $x$ \\
\hline Eucricetodon murinus & & & & & & $x$ \\
\hline Eucricetodon dubius & & aff. & & $x$ & & \\
\hline Cricetidae indet & $x$ & & & & & \\
\hline Pseudocricetodon thaleri & & & & & cf. & cf. \\
\hline Pseudocricetodon incertus & $x$ & $x$ & $x$ & $x$ & $x$ & $x$ \\
\hline Pseudocricetodon philippi & & & & aff. & & \\
\hline Pseudocricetodon moguntiacus & & & $x$ & & $x$ & cf. \\
\hline Heterocricetodon hausi & & & & & & $x$ \\
\hline Heterocricetodon gaimersheimensis & cf. & & & & $x$ & \\
\hline Heterocricetodon helbingi & & cf. & cf. & $x$ & $\hat{x}$ & \\
\hline Heterocricetodon schlosseri & & & & & $x$ & $x$ \\
\hline $\begin{array}{l}\text { Paracricetodon sp. } \\
\text { Palis }\end{array}$ & & & & & $\begin{array}{l}x \\
x\end{array}$ & \\
\hline Melissiodon schaubi & & aff. & & & & \\
\hline Heteroxerus costatus & & $x$ & & & & \\
\hline Comtia bernardi Vianey-Liaud, n. gen., n. sp. & $x$ & & & & & \\
\hline $\begin{array}{l}\text { Sciuridae indet. } \\
\text { Issiodoromys pauffiensis }\end{array}$ & $x$ & $x$ & $x$ & $x$ & $\begin{array}{l}x \\
x\end{array}$ & sp. \\
\hline $\begin{array}{l}\text { Issiodoromys pauttiensis } \\
\text { Blainvillimys stehlini }\end{array}$ & $x$ & $x$ & $x$ & $x$ & & $\begin{array}{c}\text { sp. } \\
\times\end{array}$ \\
\hline Protechimys major & $x$ & & $x$ & ? & aff. & $x$ \\
\hline Archaeomys huerzeleri & & $x$ & $x$ & $x$ & $x$ & \\
\hline Archaeomys robustus & & & & $x$ & & \\
\hline Archaeomys ehrensteini & & $x$ & & & & \\
\hline Plesiosminthus sp. & & & & & & $x$ \\
\hline Steneofiber $\mathrm{sp}$. aff. butselensis & & & & $x$ & & \\
\hline indeterminate rodent family & $x$ & & & & & $x$ \\
\hline CREODONTA & $\hat{1}$ & 0 & 0 & 1 & 0 & 0 \\
\hline Hyaenodon gervaisi & & & & $x$ & & \\
\hline Thereutherium thylacodes & $x$ & & & & & \\
\hline CARNIVORA & 1 & 2 & 0 & 2 & 2 & 1 \\
\hline Gen. et sp. indet. cf. Palaeogale sp. & $x$ & & & & & \\
\hline Carnivora indet. & & & & & $x$ & \\
\hline Pseudocyonopsis ambiguus & & $x$ & & $x$ & & \\
\hline Cynelos rugosidens & & & & $x$ & & \\
\hline Carnivora indet. & & $x$ & & & $x$ & \\
\hline Carnivora indet. & & & & & & $x$ \\
\hline Number of mammal species & 19 & 26 & 31 & 29 & 38 & 29 \\
\hline
\end{tabular}


to abundant new material from the reference locality Mas-de-Pauffié (Lot, France; MP 26). They exhibit a similar morphology and morphological variability, and represents same evolutionary stages. Therefore, the population of Issiodoromys pauffiensis from the fissure-filling of Mas-de-Pauffié, is actually as homogeneous as that the palustrine deposit of Saint-Privat-des-Vieux. A detailed analysis of the teeth of Pseudocricetodon, compared to those from Mirambueno4C (Spain, MP 26; Freudenthal 1994) and BoujacA (Gard, France; MP 27) allow to recognize in BoujacA P. landroveri, a rare species besides the abundant $P$. incertus. The species Eucricetodon huerzeleri, first described from the classical locality of Oensingen (Vianey-Liaud 1972), is also present in Saint-Privat-des-Vieux.

Comparisons with other contemporary faunas: Mas-de-Pauffié (Lot, France), Saint-Henri/SaintAndré (Bouches-du-Rhône, France), Saint-Menoux (Allier, France), Mümliswil-Hardberg and Oensingen11 (Switzerland) (Tables 9, 10).

\section{Correlation and biochronology}

Since the first biochronological subdivisions of the European continental Oligocene on the basis of rodent's evolutionary degrees (Thaler 1965, 1966), the concept of "zones", encompassing a time range with upper and lower boundaries, has evolved towards that of "standard-levels". The latter are defined by the evolutionary stages of mammalian taxa found in the standard locality, and representing a time-line (MP = Mammal Paleogene standard levels) (e.g., Jaeger \& Hartenberger 1975; Brunet \& VianeyLiaud 1987; BiochroM'97 1997: 769-794). Even if this system is not always used accurately (MP sometimes understood as zones rather than lines) it is well operating. The standard-locality for the level MP 26 is Mas-de-Pauffié, a limited fissure-filling exploited during the 1980's and the beginning of the 1990's (Vianey-Liaud \& Schmidt-Kittler 1987). It is mainly defined by the evolutionary stages of theridomyids Issiodoromys pauffiensis, Protechimys major and Blainvillimys geminatus. The date of MP 26 is estimated as about 26.5 m.y. (Table 1; after Engesser \& Mödden 1997; Escarguel et al. 1997; Vianey-Liaud 1998; Picot et al. 2008; VianeyLiaud \& Schmid 2009; Vandenberghe et al. 2012).
The two species of Theridomyidae from SaintPrivat-des-Vieux, Issiodoromys pauffensis and Protechimys major, are found together in the other localities, except in Saint-Menoux, where only I. pauffensis was recorded. This species of Issiodoromys represents an evolutionary stage prior to I. quercyi from Boningen (Switzerland; MP 27) or Ehrenstein7 (Suevish Jura, Southern Germany; MP 27); the time range of Eucricetodon huerzeleri extends from MP 26 to MP 27, as it is known in Boningen (Vianey-Liaud 1972; Engesser \& Mödden 1997), whereas that of Pseudocricetodon incertus is longer (?MP 24 to MP 27).

The teeth of the bat Cuvierimops represents a new evolutionary stage, more progressive than the one from Garouillas (MP 25 standard-level).

\section{Diversity}

Amphibian and reptile diversity. Amphibians and reptiles of only three localities from the level MP 26 are available or were studied: Saint-Privat-des-Vieux, Saint-Menoux, and Mas-de-Pauffié. Saint-Privatdes-Vieux produced the richest and most diverse fauna, which includes at least 20 species (six amphibians, one chelonian, two crocodiles, eleven squamates). Saint-Menoux yielded only nine species (four amphibians, five squamates). The fauna from Mas-de-Pauffié comprises ten species but it lacks amphibians and chelonians; it includes one crocodile and nine squamates.

Three taxa are common to these three localities (Ophisaurus s.l., amphisbaenians indeterminate, and booids indeterminate). The presence of these three taxa is not significant because they occur in most Cenozoic localities in Europe. At genus or species level, only two taxa are shared by Saint-Privat-desVieux and Saint-Menoux (Chelotriton sp., Lacerta s.l. filholi) and only two other taxa were recovered from both Saint-Privat-des-Vieux and Mas-dePauffié (Pseudeumeces, Platyspondylia), which renders comparisons difficult. It should be noted that, in addition to a cyprinid fish, at least four taxa from Saint-Privat-des-Vieux were more or less aquatic (Chelotriton, Discoglossus or Latonia, Pelophylax, crocodylian indeterminate) whereas Saint-Menoux produced two or three aquatic forms (?Chelotriton, one alytid anuran and an indeterminate anuran). 
TABLE 10. - List of vertebrates other than mammals in three western European localities correlated to MP 26 (Saint-Privat-des-Vieux, Gard, France; Saint-Menoux, Allier, France; Mas-de-Pauffié, Lot, France).

\begin{tabular}{|c|c|c|c|}
\hline & 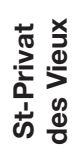 & $\begin{array}{l}\stackrel{x}{J} \\
\stackrel{0}{0} \\
\stackrel{0}{\Xi} \\
\text { ஸ }\end{array}$ & 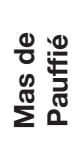 \\
\hline OSTEICHTHYES & 1 & & \\
\hline Cyprinidae indet. & $x$ & & \\
\hline $\begin{array}{l}\text { LISSAMPHIBIA } \\
\text { CAUDATA. }\end{array}$ & 6 & 4 & 0 \\
\hline $\begin{array}{l}\text { Chelotriton } \\
\text { Caudata indet. }\end{array}$ & $\begin{array}{l}\mathrm{cf} . \\
\times\end{array}$ & $\begin{array}{l}\text { sp. } \\
\times\end{array}$ & \\
\hline ANURA & & & \\
\hline Discoglossus or Latonia & $x$ & & \\
\hline Alytidae indet. & $x$ & $x$ & \\
\hline Pelophylax sp. & $x$ & & \\
\hline Anuran indet. & $x$ & $x$ & \\
\hline CHELONII & 1 & 0 & 0 \\
\hline Chelonian indet. & $x$ & & \\
\hline CROCODYLIA & 2 & 0 & 1 \\
\hline Krokolithes sp. (eggshells) & $x$ & & \\
\hline Crocodylian indet. & $x$ & & $\times$ \\
\hline SQUAMATA & 11 & 5 & 9 \\
\hline Lizards & 9 & 4 & 5 \\
\hline
\end{tabular}

Amphibians are absent from Mas-de-Pauffié and this locality yielded only one possible aquatic taxon (an indeterminate crocodilian). This clearly suggests that the environment of Mas-de-Pauffié was drier than that of Saint-Privat-des-Vieux and Saint-Menoux.

Mammalian diversity. The total number of mammal species varies between 19 for Saint-Privat-desVieux to 38 for Oensingen 11. The main differences concerns the bats, the lipotyphlans and rodents. Mas-de-Pauffié shows a striking diversity within bats (11 species) whereas their number is limited in the others (0 to 1$)$. This can be related to ecological bias, Mas-de-Pauffié being a fissure-filling, whereas the other localities are fluvio-lacustrine or pallustrine. Fissures and caves are well known to host various colonies of bats.

The only other discrepancy between the localities concerns Oensingen 11, where the number of Lipotyphla is the highest (seven compare to a maximum of three, and one for Saint-Privat); the number or rodent is also the highest (23 compare to 15 in Mümliswil-Hardberg, 11-13, for Mas-de-

\begin{tabular}{|c|c|c|c|}
\hline & 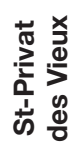 & 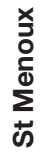 & 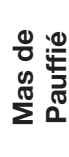 \\
\hline Lacerta filholi & cf. & $x$ & \\
\hline Pseudeumeces cadurcensis & & & $x$ \\
\hline cf. Pseudeumeces & $\times$ & & \\
\hline amblyodont indet. & $x$ & & \\
\hline Ophisaurus s.I. & $x$ & $x$ & $x$ \\
\hline ?Shinisauria indet. & $x$ & & \\
\hline Anguimorpha indet. & & & $x$ \\
\hline Amphisbaenian A & $x$ & & \\
\hline Amphisbaenian B & $x$ & & \\
\hline Amphisbaenian indet. & $x$ & $x$ & $x$ \\
\hline Lizard indet. & $x$ & $x$ & $x$ \\
\hline Serpentes & 2 & 1 & 4 \\
\hline Bavarioboa veylatsae & & & $x$ \\
\hline Bransateryx sp. & & & $x$ \\
\hline Platyspondylia sp. & $x$ & & $x$ \\
\hline Booid indet. & $x$ & $x$ & $x$ \\
\hline Number of species & 21 & 9 & 10 \\
\hline
\end{tabular}

Pauffié, Saint-Menoux, Saint-Henri/Saint-André and 10 for Saint-Privat).

The relative lower mammalian diversity of SaintPrivat-des-Vieux $(n=19)$ is easily explained by the short time of excavation. It is a limited palustrine locality, not very rich, and a little volume of sediment has been processed. The four other localities have different histories.

Saint-Menoux (Allier, France) is a long known locality (since Gaudry 1873; e.g., Stehlin 1910; Viret \& Gauthier 1950), the exploitation of which was more recently taken over (Hugueney 1980). Little is published about the stratigraphy of the locality, except that it is a fossiliferous pocket within the limestones of Saint-Menoux. Most of the small mammals (13 upon 19) and other small vertebrates have been recovered by the most recent processing of the fossiliferous pocket. Several quarries, and may be several fossiliferous pockets in the Saint-Menoux limestones could have yielded the fauna. However, the evolutionary stages of different mammals suggest a probable homogeneous age. The diversity appears of the same order than in the others (if we except the strong diversity of bats in Mas-de-Pauffié), except Oensingen 11. 
Mas-de-Pauffié (Lot, France) is a fissure filling, its processed volume being restricted to few hundred kilograms, even if the exploitation went through 20 years (mainly from 1973 to 1993; e.g., Remy et al. 1987).

Like the limestones of Saint-Menoux, the red and gray clays from Saint-Henri/Saint-André (Bouchesdu-Rhône, France) quarries have long yielded fossil vertebrates (e.g., Répelin 1916). Fossils appeared at different times and levels of the exploitation for tileries, but they came mainly from the gray clays, at the bottom of the quarries (Nury 1988). In this locality the large ungulates are relatively more diversified than elsewhere (six Artiodactyla contra four in the other localities and three contra 0-1 Perissodactyla).

Fossils from Mümliswyl-Hardberg (Solothurn, Switzerland) are known since e.g., Stehlin (1922), and were collected at differents epochs. The diversity of rodents is a little higher than in Saint-Henri/ Saint-André (16 species instead of 13 in the latter); this high diversity is mainly due to cricetids, with eight species reported (Engesser \& Mödden 1997), that is never observed in other Upper Oligocene localities (four to five), except Oensingen 11, from the same area. Oensingen 11 (Solothurn, Switzerland) displays really a surprising diversity for lipotyphlans and rodents. There are six glirid, ten cricetid and seven lipotyphlan species. This strong diversity is not the result of collecting process, because a single sediment sampling has been made, and its screen-washing provided nearly a thousand teeth, mainly of micromammals (richly fossiliferous brown marls, below a limestone bank; Engesser \& Mödden 1997). Such a rodent diversity (23 species) could indicate an environment different than in the other localities. Is it due to a difference of latitude, the French localities laying south to the Swiss one? If the latitudinal difference is not important, more local geographical aspects could be taken into account. Oensingen 11 is localized in the Alpine Foreland Basin. The effects of tectonics (marine regression around $30 \mathrm{My}$ followed by the deposition of the freshwater molasse [e.g., Schlunegger et al. 1999]), and the glaciation episodes until $28 \mathrm{My}$ (Van Simaeys \& Vanderberghe 2006, Vanderberghe et al. 2012) may have resulted in the differentiation of environments during the time between MP 25/ MP 26 biochronological benchmarks. Following these glaciations, the diversity of rodents fell down in french localities (MP 26; e.g., Vianey-Liaud 1991). A rise in diversity is observed since the level of Pech Desse (MP 28a; $\mathrm{n}=16$ species) in French localities. In the well sampled localities close to MP 28, the number of rodents is 16 to 17, as well in Vivel del Rio (Spain; Hugueney et al. 1987; $\mathrm{n}=17$ ), as in Gaimersheim (Germany; e.g., Kristkoiz 1992, $\mathrm{n}=16$ ) or Pech du Fraysse (Vianey-liaud 1991; $\mathrm{n}=17)$. The Oensingen 11 rodent list exhibits a diversity unknown before the very end of the Oligocene for French localities (Coderet, MP 30, n = 24 rodents species and nine lypotyphlans), when prevails a warmer and more humid climate.

Therefore, if the strong diversity in Oensingen $11-$ and to a lesser extant in Mümliswil-Hardberg - might not be due to ecological parameters, it could be a taxonomical bias. It may be due to the overestimation of the number of some taxa, like cricetids, and perhaps glirids and lypotyphlans species. The Chattian rodents diversity in Swiss localities varies between 15 and 21 (Engesser \& Mödden 1997), independently of the biochronological level: 1516 in Mümliswil-Hardberg (MP 26), Rickenbach (MP 29) and Küttingen (MP 30); 19 in Fluh 19/20 (MP 29); and 20-21 in Fornant6 (MP 28) and Wynau1 (MP 27). In these localities, the diversity of lypotyphlans varies from two to five. As the small mammal fauna of Oensingen 11 has not been described and figured, the issue remains outstanding.

\section{CONCLUSION}

A short-time sampling (only once) in a small area of a thin, but richly fossiliferous, layer allows ensuring the restricted temporal extension of the fauna from Saint-Privat-des-Vieux (Gard, France). Beyond their description, 21 species of vertebrates other than mammals, and 19 mammals, have brought consistent evidence on paleoenvironmental and taphonomic conditions. They reflect a water depositional environment, as well as nearby open areas. 
The sampling conditions (short time and small area) could be disadvantageous regarding the representation of macromammals, but even in this case, some artiodactyls, a creodont and a carnivor are represented, and not much less than in other contemporaneous localities, like Saint-Menoux. Among the micromammals, two of the three theridomyids are biochronological markers of MP 26 reference level. Furthermore, the morphological variability of one of them (Issiodoromys pauffiensis) is nearly similar as that observed in the population of the standard-locality Mas-de-Pauffié; this confirms the accuracy of the latter as representative of a homogeneous evolutionary stage. It is the same for the well-documented cricetid species Pseudocricetodon incertus. Otherwise, despite the conditions of collecting, unusual rodents such as a sciurid (Comtia bernardi Vianey-Liaud, n. gen., n. sp.) and a possible aplodontid, are recorded, as well as the rare Creodonta Thereutherium. Finally, it has been possible to make a significant comparison of the diversity of Saint-Privat-des-Vieux mammalian fauna with that of contemporaneous localities inasmuch these localities have been properly described and analyzed.

\section{Acknowledgements}

Bernard $†$ Comte has made the observations, measurements and tables for the cricetids, along the 2011-2012's. He passed away in January 2013 after a short and painful illness.

We are endebted to Helene Lardet and André Bonnet, who have contacted us to report the presence of bones in the trench of Saint-Privat-des-Vieux; to Jean Remy for its participation to the sampling; to Claire Sagne and Christine Argot (MNHN) for allowing access to the collections from Quercy; to Loïc Costeur (Naturhistorisches Museum, Basel) for informations on the Basel collections, to Gertrud Rössner, Bayerische Staatssammlung für Paläontologie und Geologie, Munchen, for the loan of Issiodoromys quercyi from Ehrenstein7 and to Norbert Schmidt-Kittler for bringing us this material.

Many thanks to Marc Augé, Marguerite Hugueney and Sevket Sen for their very constructive reviews of the manuscript.

ISEM publication $\mathrm{n}^{\circ} 2014-104$.

\section{REFERENCES}

AugÉ M. 2005. — Évolution des lézards du Paléogène en Europe. Mémoires du Muséum national d'Histoire naturelle 192: 5-369.

Augé M. \& RAGE J. C. 1995. — Le Garouillas et les sites contemporains (Oligocène, MP 25) des Phosphorites du Quercy (Lot, Tarn-et-Garonne, France) et leurs faunes de Vertébrés. 2. Amphibiens et Squamates. Palaeontographica A 236: 11-32.

Augé M. \& RAGE J. C. 2000. - Les Squamates (Reptilia) du Miocène moyen de Sansan, in GINSBURG L. (ed.), La faune miocène de Sansan et son environnement. Mémoires du Muséum national d'Histoire naturelle 183: 263-313.

Augé M. \& SMith R. 2009. - An assemblage of early Oligocene lizards (Squamata) from the locality of Boutersem (Belgium), with comments on the EoceneOligocene transition. Zoological Journal of the Linnean Society 155: 148-170.

BAILON S. 1989. - Les amphibiens et les reptiles du Pliocène supérieur de Balaruc II (Hérault, France). Palaeovertebrata 19: 7-28.

Bailon S., Rage J. C. \& Stoetzel E. 2011. - First fossil representative of the salamander crown-group from a Gondwanan continent: Pleurodeles cf. waltl from the Quaternary of Morocco. Amphibia-Reptilia 32: 245-252.

BiochroM'97 1997. — Actes du congrès BiochroM'97, sur la "Biochronologie Mammalienne du Cénozoïque en Europe et Domaines reliés, in AgUILAR J. P., LEGENDRE S. \& Michaux J. (eds), Mémoires et Travaux de l'Institut de Montpellier de l'École Pratique des Hautes Études 21, 818 p.

Biton R., Geffen E., Vences M., Cohen O., Bailon S., Rabinovich R., Malka Y., Oron T., Boistel R., BRUMFELD V. \& GAFNY S. 2013. - The rediscovered Hula painted frog is a living fossil. Nature Communications 4: 1959. http://dx.doi.org/10.1038/ncomms2959

BLONDEL C. 1996. — Les ongulés à la limite Éocène/ Oligocène et au cours de l'Oligocène en Europe occidentale: analyses faunistiques, morpho-anatomiques et biogéochimiques (d13C et $\mathrm{d} 18 \mathrm{O})$. Implications sur la reconstitution des paléoenvironnements. Unpublished PHD thesis, University Montpellier 2, France, 119 p. and appendices A1-A24.

Blondel C. 1997. - Les ruminants de Pech Desse et Pech du Fraysse (Quercy; MP 28); évolution et relations des ruminants de l'Oligocène d'Europe. Geobios 30: 573-591.

BlONDEL C. 1998. - Le squelette appendiculaire de sept ruminants oligocènes d'Europe: implications paléoécologiques. Comptes rendus de l'Académie des Sciences 326: 527-532.

Blondel C. 2005. - New data on the Cainotheriidae (Mammalia, Artiodactyla) from the early Oligocene 
of south-western France. Zoological Journal of the Linnean Society 144: 145-166.

BÖHME M. 2008. - Ectothermic vertebrates (Teleostei, Allocaudata, Urodela, Anura, Testudines, Choristodera, Crocodylia, Squamata) from the Upper Oligocene of Oberleichtersbach (Northern Bavaria, Germany). Courier Forschungsinstitut Senckenberg 260: 161-183.

BÖHME M. 2010. — Ectothermic vertebrates (Actinopterygii, Allocaudata, Urodela, Anura, Crocodylia, Squamata) from the Miocene of Sandelzhausen (Germany, Bavaria) and their implications for environment reconstruction and palaeoclimate. Palaeontologie Zeitschrift 84: 3-41.

Bonnet A., Comte B., LaRdet H., Marandat B., Remy J. A., Sudre J. \& Vianey-Liaud M. 2011. - Le gisement à mammifères de Saint-Privat-des-Vieux (Gard), un nouveau repère chronologique dans la sédimentation du fossé oligocène d'Alès. Bulletin de la Société d'Études en Sciences naturelles 68: 9-18.

BRUijn H. DE \& ÜNAY E. 1989. — Petauristinae (Mammalia, Rodentia) from the Oligocene of Spain, Belgium and Turkisch Thrace. Natural History Museum Los Angeles County, Science Series 33: 139-146.

Bruijn H. DE, ÜNay E., SaraÇ G. \& Yilmaz A. 2003. — A rodent assemblage from the Eo/Oligocene boundary interval near Süngülü, Lesser Caucasus, Turkey. Coloquios de Paleontologia, extra volume 1: 47-76.

BRunet M. \& Sudre J. 1987. - Evolution et systématique du genre Lophiomeryx Pomel, 1853 (Mammalia, Artiodactyla). Münchner Geowissenschaftliche Abhandlungen A 10: 225-242.

BRUNET M. \& VianeY-LiAud M. 1987. - Mammalian Reference levels MP 21-30, in International Symposium on Mammalian Biostratigraphy and Paleoecology of the European Paleogene-Mainz. Münchner Geowissenschaftliche Abhandlungen A 10:30-31.

Čerñanský A., Rage J. C. \& Klembara J. 2014. - The Early Miocene squamates of Amöneburg (Germany): the first stages of modern squamates in Europe. Journal of Systematic Palaeontology. http://dx.doi.org/10.108 0/14772019.2014.897266

COMTE B. 1985. - Éléments nouveaux sur l'évolution des genres Eucricetodon et Pseudocricetodon (Eucricetodontinae, Rodentia, Mammalia) de l'Oligocène d'Europe occidentale. Palaeovertebrata 15: 1-69.

Comte B. \& Vianey-Liaud M. 1987. — Nouveaux Eomyidae du Paléogène d'Europe Occidentale. Comptes rendus de l'Académie des sciences 304, II, 15: 951-955.

Comte B., Sabatier M., Marandat B. \& VianeyLIAUD M. 2012. — Les rongeurs de Chery-Chartreuve et Rocourt-Saint-Martin (Est du Bassin de Paris ; Aisne, France). Leur place parmi les faunes de l'Éocène supérieur d'Europe. Palaeovertebrata 37: 169-270.

Conrad J. L., Ast J. C., Montanari S. \& Norell M. A. 2011. - A combined evidence phylogenetic analysis of Anguimorpha (Reptilia: Squamata). Cladistics 27: 230-277.
Crochet J. Y. 1995. — Le Garouillas et les sites contemporains (Oligocene, MP 25) des phosphorites du Quercy (Lot, Tarn-et-Garonne, France) et leurs faunes de vertébrés. 4. Marsupiaux et insectivores. Palaeontographica Abteilung A 236: 39-75

DaAms R., Freudenthal M., Lacomba J. I. \& AlvaREZ M. A. 1989. - Upper Oligocene micromammals from Pareja, Loranca Basin, prov. of Guadalajara, Spain. Scripta Geologica 89: 27-56.

Delfino M. \& Smith T. 2012. - Reappraisal of the morphology and phylogenetic relationships of the middle Eocene alligatoroid Diplocynodon deponiae (Frey, Laemmert and Riess, 1987) based on a threedimensional specimen. Journal of Vertebrate Paleontology 32: 1358-1369.

Depéret CH. 1917. - Monographie de la faune de mammiferes fossiles du Ludien inférieur d'Euzet-les-Bains (Gard). Annales de l'Université de Lyon, n.s. 40: 290 p.

Dieneman A. 1987. - Die Gattungen Eucricetodon und Pseudocricetodon (Rodentia, Mammalia) aus dem Oligozän Süddeutschlands. Abhandlungen/Bayerische Akademie der Wissenschaften, Mathematische-Naturwissenschaftliche Klasse 165, 158 p.

Engesser B. 1987. - New Eomyidae, Dipodidae, and Cricetidae (Rodentia, Mammalia) of the Lower Freshwater Molasse of Switzerland and Savoy. Eclogae Geologicae Helvetiae 80: 943-994.

ENGESSER B. \& MÖDDEN C. 1997. - A new version of the biozonation of the Lower Freshwter Molasse (Oligocene and Agenian) of Switzerland and Savoy on the basis of fossil mammals, in BiochroM'97, Mémoires et Travaux de l'Institut de Montpellier de l'École Pratique des Hautes Etudes 21: 475-500.

Escarguel G., Marandat B. \& LegendRe S. 1997. — Sur l'âge numérique des faunes de mammiferes du Paléogène d'Europe occidentale, en particulier celles de l'Eocène inférieur et moyen, in BiochroM'97, Mémoires et Travaux de l'Institut de Montpellier de l'École Pratique des Hautes Études 21: 443-460.

FilHol H. 1876. - Mammifères fossiles nouveaux provenant des dépôts de phosphate de chaux du Quercy. Comptes rendus hebdomadaires des Séances de l'Académie des Sciences, Paris 82: 288, 289.

FilHOL H. 1877. - Recherches sur les phosphorites $d u$ Quercy. Étude des fossiles qu'on y rencontre et spécialement des mammiferes. G. Masson, Paris, $561 \mathrm{p}$.

FreudenberG H. 1941. - Die oberoligozänen Nager von Gaimesrsheim bei Ingolstadt und ihre Verwandten. Palaeontographica Abteilung A 92: 99-164.

Freudenthal M. 1994. — Cricetidae (Rodentia, Mammalia) from the Upper Oligocene of Mirambueno and Vivel del Rio (prov. Teruel, Spain). Scripta Geologica 104: 1-55.

Freudenthal M. 1996. - The Early Oligocene rodent fauna of Olalla 4A (Teruel, Spain). Scripta Geologica 112: 1-67. 
Freudenthal M., Hugueney M. \& Moissenet E. 1994. - The genus Pseudocricetodon (Cricetidae, Mammalia) in the Upper Oligocene of the province of Teruel (Spain). Scripta Geologica 104: 57-114.

GAUDRY A. 1873. - Animaux fossiles du Mont Léberon (Vaucluse), Étude sur les vertébrés. F. Savy, Paris, 112 p.

GeraAds D., Bouvrain G. \& Sudre J. 1987. — Relations phylétiques de Bachitherium Filhol, ruminant de l'Oligocène d'Europe occidentale. Palaeovertebrata 17 (2): 43-73.

GERVAIS P. 1848-1852. - Zoologie et Paléontologie françaises (animaux vertébrés), Bertrand, Paris, 3 volumes: 271 p., 45 pls.

GERVAIS P. 1856. - Sur les mammifères fossiles que l'on a recueillis dans le département du Gard. Comptes rendus hebdomadaires des Séances de l'Académie des Sciences 42: 1159-1161.

Gomes Rodrigues H., Marivaux L. \& Vianey-Liaud M. 2013. - On the status of early Eucricetodontinae (Muroidea, Rodentia) with a special focus on the Atavocricetodon vs Eucricetodon issue: morphometri$\mathrm{cal}$ and microstructural aspects. Spanish Journal of Paleontology 28: 17-28.

Hartenberger J.-L., Sigé B., Sudre J. \& VianeyLiaUd M. 1970. — Nouveaux gisements de Vertébrés dans le Bassin tertiaire d'Alès (Gard). Bulletin de la Société géologique de France 7: 879-885.

HiRSCH K. F. 1985. - Fossil crocodylian eggs from the Eocene of Colorado. Journal of Palaeontology 59: 531-542.

Hirsch K. F. \& Kohring R. 1992. — Crocodilian eggs from the Middle Eocene Bridger Formation, Wyoming. Journal of Vertebrate Paleontology 12: 59-65.

Holman J. A. \& Harrison D. L. 1998. — A new genus of snake (Serpentes: Boidae) from the Upper Eocene of Hordle Cliff, Hampshire, England. Acta Zoologica Cracoviensia 41: 23-27.

Hugueney M. 1967. — Les Rongeurs (Mammalia) de l'Oligocène supérieur de Coderet - Bransat (Allier). Documents du Laboratoire de Géologie de la Faculté des Sciences de Lyon 34: 1-227.

Hugueney M. 1980. — La faune de mammifères de l'Oligocène moyen de Saint-Menoux (Allier). Revue Scientifique du Bourbonnais et du Centre de la France 1 re partie: Rongeurs: 57-72.

Hugueney M. 1999. - Genera Eucricetodon and Pseudocricetodon, in RÖSSNER G. \& HeISSIG K. (eds), The Miocene Land Mammals of Europe. Friedrich Pfeil, Munich: 347-358.

Hugueney M. \& Guérin C. 1981. — La faune de mammifères de l'Oligocène moyen de Saint-Menoux (Allier). Revue Scientifique du Bourbonnais et du Centre de la France, $2^{e}$ partie: Marsupiaux, Chiroptères, Insectivores, Carnivores, Périssodactyles, Artiodactyles (Mammalia): 52-71.
Hugueney M., Adrover R., Moissenet E. \& SCHMidtKITTLER N. 1987. — Les Mammifères de Vivel del Rio (prov. de Teruel, Espagne; Oligocène supérieur): un riche gisement stratifié en comparaison avec des faunes karstiques. Münchner Geowissenschaftliche Abhandlungen A 10: 117-130.

Jaeger J.-J. \& Hartenberger J.-L. 1975. — Pour l'utilisation systématique de niveaux-repères en biochronologie mammalienne. 3e Réunion Annuelle des Sciences de la Terre. Montpellier, $201 \mathrm{p}$.

KeARnEY M. 2003. - Systematic of the Amphisbaenia (Lepidosauria: Squamata) based on morphological evidence from recent and fossil forms. Herpetological Monographs 17: 1-74.

KALTHOFF D. 2006. - Incisor enamel microstructures and its implications to the systematics of Eurasian Oligocene and lower Miocene hamsters. Palaeontographica Abteilung A 277: 67-80.

KlEMBARA J. 2008. - A new anguimorph lizard from the Lower Miocene of north-west Bohemia, Czech Republic. Palaeontology 51: 81-94.

Kohring R. \& HirsCH K. F. 1996. - Crocodilian and avian eggshells from the middle Eocene of the Geiseltal, Eastern Germany. Journal of Vertebrate Paleontology 16: 67-80.

KRISTKOIZ A. 1992. - Zahnmorphologische und schadelanatomische Untersuchungen an Nagertieren aus dem Oberoligozän von Gaimersheim (Süddeutschland). Abhandlungen / Bayerische Akademie der Wissenschaften, Mathematische-Naturwissenschaftliche Klasse 167: 1-137.

LANGE-BADRÉ B. 1979. - Les créodontes (Mammalia) d'Europe occidentale de l'Éocène supérieur à l'Oligocène supérieur. Mémoires du Muséum national d'Histoire naturelle, nouvelle série, Série C Sciences de la Terre 42: 1-249.

LANGE-BADRÉ B. 1995. - Le Garouillas et les sites contemporains (Oligocène, MP 25) des phosphorites du Quercy (Lot, Tarn-et-Garonne, France) et leurs faunes de Vertébrés. 6. Créodontes. Palaeontographica A 236: 125-133.

LEGENDRE S. 1995. - Le Garouillas et les sites contemporains (Oligocène MP 25) des phosphorites du Quercy (Lot, Tarn et Garonne, France) et leurs faunes de vertébrés: 14-Paléoécologie. Palaeontographica A 236: 327-343.

Lihoreau F., Ducroce S., Antoine P.O., Vianey-Liaud M., RafaŸ S., Garcia G. \& Valentin X. 2009. - First complete skulls of Elomeryx crispus (Gervais, 1849) and of Protaceratherium albigense (Roman, 1912) from a new Oligocene locality near Moissac (SW France). Journal of Vertebrate Paleontology 29: 242-253.

Maridet O., Hugueney M. \& Heissig K. 2010. — New data about the diversity of Early Oligocene eomyids (Mammalia, Rodentia) in Western Europe. Geodiversitas 32 (2): 221-254. http://dx.doi.org/10.5252/ g2010n2a3 
Martin J. \& Gross M. 2011. — Taxonomic clarification of Diplocynodon Pomel, 1847 (Crocodilia) from the Miocene of Styria, Austria. Neues Jahrbuch für Geologie und Paläontologie, Abhandlungen 261: 177-193.

Martinez J. N. \& SUdRE J. 1997. — The astragalus of Paleogene artiodactyls: comparative morphology, variability and prediction of body mass. Lethaia 28 : 197-209.

Ménouret B. \& Guérin G. 2009. - Diceratherium massiliae nov. sp. des argiles oligocènes de Saint-André et Saint-Henri à Marseille et Les Milles près d'Aix-enProvence (SE de la France), premier grand Rhinocerotidae brachypode européen. Geobios 42: 293-327.

MÖDDEN C. 1993. — Revision der Archaeomyini Schlosser (Rodentia, Mammalia) des europäischen Oberoligozän. Mémoires suisses de Paléontologie 115: 1-83.

Mödden C. \& Vianey-Liaud M. 1997. - The Upper Oligocene tribe Archaeomyini (Theridomyidae, Rodentia, Mammalia): systematics and biostratigraphy, in BiochroM'97, Mémoires et Travaux de l'Institut de Montpellier de l'École Pratique des Hautes Études 21: $361-374$.

Morlo M. 1996. — Carnivoren aus dem Unter-Miozän des Mainzer Beckens (2. Mustelidae, Pinnipedia, Feliformia, Palaeogale). Senckenbergiana lethaea 76: 193-249.

Morlo M. \& GunNell G. F. 2003. - Small limnocyonines (Hyaenodontidae, Mammalia) from the Bridgerian Middle Eocene of Wyoming: Thinocyon, Prolimnocyon, and Iridodon, new genus. Contributions from the Museum of Paleontology, University of Michigan 31: 43-78.

NURY D. 1988. — L'Oligocène de Provence méridionale, stratigraphie-dynamique sédimentaire, reconstitutions paléogéographiques. Documents du BRGM 163, 395 p.

Picot L., Becker D., Cavin L., Pirkenser C., Lapaire F., Rauber G., Hochuli P.A., Spezzaferri S. \& Berger J.-P. 2008. - Sédimentologie et Paléontologie des paléoenvironnements côtiers rupéliens de la molasse marine rhénane dans le Jura Suisse. Swiss Journal of Geosciences 101: 483-513.

RAGE J. C. 1987. - Extinctions chez les Squamates (Reptiles) à la fin de l'Oligocène en France. Adaptations et modifications de l'environnement. Mémoires de la Société géologique de France 150: 145-149.

RAGE J. C. \& ROČEK Z. 2003. - Evolution of anuran assemblages in the Tertiary and Quaternary of Europe, in the context of palaeoclimate and palaeogeography. Amphibia-Reptilia 24: 133-177.

RAGE J. C. \& AUGÉ M. 2010. - Squamate reptiles from the middle Eocene of Lissieu (France). A landmark in the middle Eocene of Europe. Geobios 43: 253-268.

Remy J.A., Crochet J.-Y., Sigé B., Sudre J., Bonis L. DE, Vianey-Liaud M., GOdinOt M., HaRTENBERGER J.L., LANGe-BADRE B. \& COMTE B. 1987. - Biochronologie des phosphorites du Quercy: mise à jour des listes fauniques et nouveaux gisements de mammifères fossiles. Münchner Geowissenschaftliche Abhandlungen A 10: 169-188.

RENSBERGER J. M. 1983. - Successions of meniscomyine and allomyine rodents (Aplodontidae) in the OligoMiocene John Day Formation, University of California Publications in Geological Sciences 124: 1-157.

RÉPELIN J. 1916. — Sur l'âge des dépôts oligocènes des bassins d'Aix et de Marseille et en particulier des argiles des Milles et des lignites de Saint-Zacharie. Comptes rendus sommaires des Séances de l'Académie des Sciences 163: 100-102.

Riley J., Winch J.M., Stimson A. F. \& Pope R. D. 1986. - The association of Amphisbaena alba (Reptilia: Amphisbaenia) with the leaf-cutting ant Atta cephalotes in Trinidad. Journal of Natural History 20: 459-470.

RočEK Z. 1994. - Taxonomy and distribution of Tertiary discoglossids (Anura) of the genus Latonia V. Meyer, 1843. Geobios 27: 717-751.

RočeK Z. \& RAgE J. C. 2000. - Tertiary Anura of Europe, Africa, Asia, and North America, in HEATwole H. \& Carroll R. L. (eds), Amphibian Biology, vol. 4: Palaeontology. Surrey Beatty and Sons, Chipping Norton: 1332-1387.

ROMAN F. 1903. - Contributions à l'étude des bassins lacustres de l'Éocène et de l'Oligocène du Languedoc. Bulletin de la Société géologique de France, 4e série, III, 5: 546-616.

Sanchiz B., Schleich H. H. \& Esteban M. 1993. - Water frogs (Ranidae) from the Oligocene of Germany. Jounal of Herpetology 27: 486-489.

SCHAub S. 1925. - Die hamsterartigen Nagetiere des Tertiärs und ihre lebenden Verwandten. Abhandlungen der Schweizerischen Palaeontologischen Gesellschaft 45: 1-114.

SChleich H. H. 1988. - Neue Reptilienfund aus dem Tertiär Deutschlands. 8. Palaeoblanus tobieni n. g. n. sp. - neue Doppelschleichen aus dem Tertiär Deutschlands. Paläontologie Zeitschrift 62: 92-105.

SchlunegGer F., Burbank D.W., Matter A., Engesser B. \& Mödden C. 1999. - Magnetostratigraphic calibration of the Oligocene to Middle Miocene (30-15 My) mammal biozones and depositional sequences of the Swiss molasses basin. Eclogae geologicae Helvetiae 89: 753-788.

SChmidT-Kittler N. \& Vianey-Liaud M. 1979. —-Evolution des Aplodontidae oligocènes européens. Palaeovertebrata 9: 33-82.

SCHMidT-KitTler N. \& Vianey-Liaud M. 1987. - Morphometric analysis of the genus Issiodoromys (Theridomyidae, Rodentia) of the European Oligocene. Proceedings of the Koninklijke Nederlandse Akademie van Wetenschappen B 90: 281-306.

SChmidt-KitTler N., Vianey-Liaud M., Comte B. \& MÖDDEN C. 1997. - Biostratigraphic relevance of the rodent genus Issiodoromys in the European 
Oligocene, in BiochroM'97, Mémoires et Travaux de l'Institut de Montpellier de l'École Pratique des Hautes Études 21: 375-396.

SigÉ B. 1995. - Le Garouillas et les sites contemporains (Oligocène MP 25) des phosphorites du Quercy (Lot, Tarn et garonne, France) et leurs faunes de vertébrés: Chiroptères, Palaeontographica Abteilung A 236, 1-6: 77-124.

Simpson G.G., Roe A. \& LeWontin R. 1960. — Quantitative Zoology. Harcourt, Brace \& Co., New York, $440 \mathrm{p}$.

STEHLIN H. G. 1910. — Die Säugetiere des schweitzerischen Eocaens. Ge part. Mémoire de la Société Paléontologique suisse 36: 838-1164.

STEHLIN H. G. 1922. — Säugetierpaläontologische Bemerkungen zur Gliederung der oligozanen Molasse. Eclogae geologicae Helveticae 16: 575-581.

SUDRE J. 1986. - Le genre Bachitherium FILHOL, 1882 (Mammalia, Artiodactyla), diversité spécifique, phylogénie, extension chronologique. Comptes rendus de l'Académie des Sciences II 303: 749-754

SUDRE J. 1995. - Le Garouillas et les sites contemporains (Oligocène, MP 25) des phosphorites du Quercy (Lot, Tarn-et-Garonne, France) et leurs faunes de Vertébrés. 12. Les artiodactyles. Palaeontographica Abteilung A 236: 205-256.

SZALAY F. S. 1969. - Mixodectidae, Microsyopidae, and the insectivore-primate transition. Bulletin of the American Museum of Natural History 140: 193-330

SZYNDLAR Z. \& RAGE J. C. 2003. - Non-Erycine Booidea from the Oligocene and Miocene of Europe. Institute of Systematics and Evolution of Animals, Cracovie, $109 \mathrm{p}$.

SzyNDlar Z., Smith R. \& Rage J. C. 2008. - A new dwarf boa (Serpentes, Booidea, 'Tropidophiidae') from the Early Oligocene of Belgium: a case of the isolation of Western European snake faunas. Zoological Journal of the Linnean Society 152: 393-406.

THALER L. 1965. — Une échelle de zones biochronologiques pour les Mammiferes du Tertiaire d'Europe. Compte rendu sommaire des Séances de la Société géologique de France 4: 118.

THALER L. 1969. — Nouveaux rongeurs de l'Oligocène moyen d'Espagne. Palaeovertebrata 2: 191-207.

Thorington R. W. JR., SCHENNUM C. E., PAPPAS L. A. \& Pitassy D. 2005. - The difficulties of identifying flying squirrels (Sciuridae: Pteromyini) in the fossil record. Journal of Vertebrate Paleontology 25: 950-961.

Trofimov B. A. 1957. - Nouvelles données sur les Ruminantia les plus anciens d'Asie. Cursillos y Conferiences del Instituto "Lucas Mallada" 4: 137-141.

Van Simaeys S. \& Vandenberghe N. 2006. - Rupelian. Geologica Belgica 9: 95-101.

Vandenberghe N., Hilgen F. J. \& Speijer R. P. 2012. - The Paleogene Period, in GradsteIn F.M., OgG J.G., Schmitz M. \& OGG G. (eds), The Geologic Time Scale. Elsevier, 856-907.
Van Valen L. M. 1966. — Deltatheridia, a new order of mammals. Bulletin of the American Museum of Natural History 132: 1-126.

Vianey-Liaud M. 1972. - Contribution à l'étude des Cricétidés oligocènes d'Europe occidentale. Palaeovertebrata 5: 1-44.

Vianey-Liaud M. 1974. — L'anatomie des genres Eucricetodon et Pseudocricetodon (Cricetidae, Rodentia, Mammalia). Géologie Méditerranéenne 1: 111-132.

VIANEY-Liaud M. 1976. — Les Issiodoromyinae (Rodentia, Theridomyidae) de l'Éocène supérieur à l'Oligocène inférieur en Europe Occidentale. Palaeovertebrata 7: $1-115$.

Vianey-Liaud M. 1979. - Évolution des rongeurs à l'Oligocène en Europe Occidentale. Palaeontographica A 166: 136-236.

Vianey-Liaud M. 1991. — Les rongeurs de l'Éocène terminal et de l'Oligocène d'Europe comme indicateurs de leur environnement. Palaeogeography, Palaeoclimatology, Palaeoecology 85: 15-28.

VianeY-Liaud M. 1994. — La radiation des Gliridae (Rodentia) à l'Éocène supérieur en Europe Occidentale, et sa descendance Oligocène. Münchner Geowissenschaftliche Abhandlungen 26: 117-160.

VIANEY-LIAUd M. 1998. — La radiation des Theridomyidae (Rodentia) à l'Oligocène inférieur: modalités et implications biochronologiques. Geologica et Palaeontologica 32: 253-285.

VianeY-Liaud M. \& LegendRe S. 1986. — Les faunes des phosphorites du Quercy: principes méthodologiques en paléontologie des mammifères; homogénéité chronologique des gisements de mammifères fossiles. Eclogae Geologicae Helvetiae 79: 917-944.

VianeY-Liaud M. \& SChMidT-KitTler S. 1987. — Biostratigraphie de l'Oligocène d'Europe: importance des lignées guides de rongeurs Theridomyidae, et particulièrement des Issiodoromyinae. Münchner Geowissenschaftliche Abhandlungen A 10: 211-216.

Vianey-Liaud M. \& Ringeade M. 1993. — La radiation des Theridomyidae (Rodentia) hypsodontes à l'Eocène supérieur. Geobios 26: 455-495.

Vianey-Liaud M. \& Schmid B. 2009. - Diversité, datation et paléoenvironnement de la faune de mammifères oligocène de Cavalé (Quercy, SW France): contribution de l'analyse morphométrique des Theridomyinae (Mammalia, Rodentia), in PEIGNÉ S. \& Merceron G. (eds), Louis de Bonis : 50 ans de recherches paléontologiques sur les mammifères. Geodiversitas 31 (4): 909-941. http://dx.doi. org/10.5252/g2009n4a909

Vianey-Liaud M., Comte B. \& Lévêque F. 1995. — Le Garouillas et les sites contemporains (Oligocène MP 25) des phosphorites du Quercy (Lot, Tarn et Garonne, France) et leurs faunes de vertébrés: Rongeurs. Palaeontographica A 236: 257-326.

Vianey-Liaud M., Hautier L. \& Marivaux L. (in 
press). - Morphological disparity of the postcranial skeleton of the Theridomyidae (Rodentia, Mammalia) from the Paleogene of Western Europe, in Cox P. \& HAUTIER L. (eds), Evolution of the Rodents: Advances in Phylogenetics, Functional Morphology and Development. Cambridge, Cambridge University Press.

VIRET J. \& GAUTHIER H. 1950. — Sur l'âge des calcaires de Saint-Menoux (Allier). Comptes rendus hebdomadaires des séances de l'Académie des Sciences 230: 221-223.
Werner J. 1994. — Beiträge zur Biostratigraphie der Unteren Süsswasser-Molasse Süddeutschlands Rodentia und Lagomorpha (Mammalia) aus den Fundstellen der Ulmer Gegend. Stuttgarter Beiträge zur Naturkunde. Serie B (Geologie und Paläontologie) 200: 1-263.

Wood A. E. \& Wilson R. W. 1936. — A suggested nomenclature for the cusps of the cheek teeth of rodents. Journal of Paleontology 10: 388-391.

Submitted on 16 January 2014; accepted on 16 June 2014; published on 26 December 2014. 